\title{
HERPETOFAUNA OF THE \\ YUTAJÉ-COROCORO MASSIF, \\ VENEZUELA: SECOND REPORT FROM \\ THE ROBERT G. GOELET \\ AMERICAN MUSEUM-TERRAMAR \\ EXPEDITION \\ TO THE NORTHWESTERN TEPUIS
}

\author{
CHARLES W. MYERS \\ Curator Emeritus \\ Division of Vertebrate Zoology (Herpetology) \\ American Museum of Natural History \\ New York, New York \\ MAUREEN A. DONNELLY \\ Research Associate \\ Division of Vertebrate Zoology (Herpetology) \\ American Museum of Natural History \\ Associate Professor, Biological Sciences \\ Florida International University
}

BULLETIN OF THE AMERICAN MUSEUM OF NATURAL HISTORY

Number 261, 85 pp., 50 figures, 2 tables

Issued May 9, 2001

Price: $\$ 15.00$ a copy 


\section{CONTENTS}

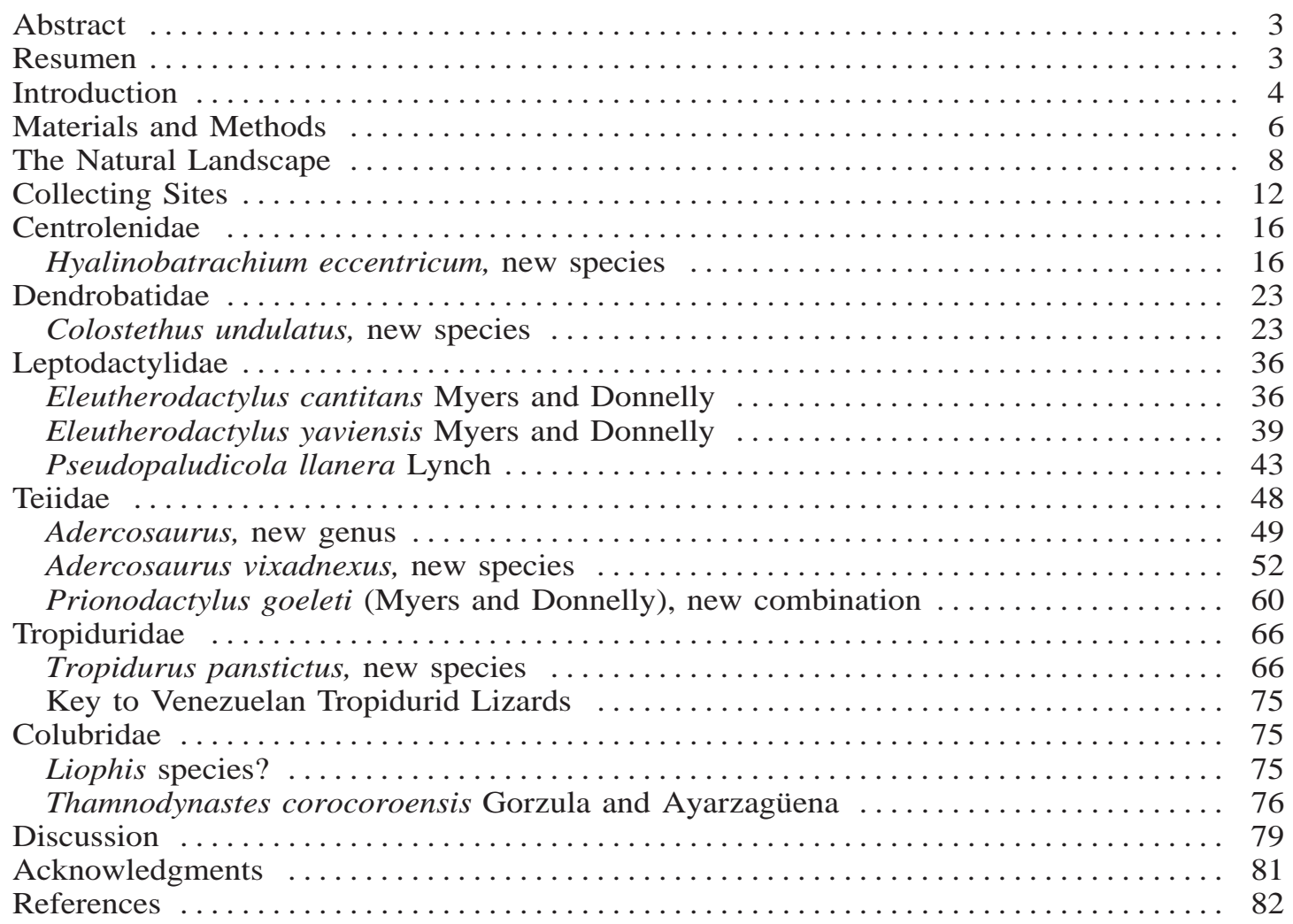




\begin{abstract}
The Yutajé-Corocoro massif is a highly eroded sandstone table mountain, with internal drainage mainly to the central valley of the Río Corocoro, a stream in the headwater drainage of the Río Manapiare-some $100 \mathrm{~km}$ east of the middle Río Orinoco, at the northern edge of the State of Amazonas in southern Venezuela. The rocky soil supports a mosaic of diverse scrubland and forest, with small tepui meadows at the higher elevations. The herpetofauna is depauperate, as is typical of the Venezuelan tepuis.

Eight species of amphibians and reptiles were collected during a 7-day period in the dry season (February). This sample includes two new frogs (Hyalinobatrachium eccentricum, n. sp., Centrolenidae; Colostethus undulatus, n. sp., Dendrobatidae) and a new genus and species of lizards (Adercosaurus vixadnexus, n. gen. \& sp., Teiidae), all of which were found in humid montane mossy forest at 1700-1750 m elevation. Another new lizard (Tropidurus panstictus, n. sp., Tropiduridae) was discovered at lower elevations $(180-1220 \mathrm{~m})$, especially in dry scrub.

The fauna also includes a widespread lowland frog (Pseudopaludicola llanera Lynch), two tepui frogs (Eleutherodactylus cantitans Myers and Donnelly; E. yaviensis Myers and Donnelly), a tepui lizard (Prionodactylus goeleti [Myers and Donnelly], new combination), a snake (Liophis?) that escaped capture, and another snake (Thamnodynastes corocoroensis Gorzula and Ayarzagüena) obtained by S. Gorzula in 1987. The two Eleutherodactylus and the Prionodactylus also occur on neighboring Cerro Yaví (the type locality), although one of the frogs (E. yaviensis) and the lizard show evidence of differentiation. Based on the original description, the snake Thamnodynastes corocoroensis appears to be distinct from a related species on Cerro Yaví.

Two of the new species exhibit characters that are novel or not previously noted. The dendrobatid frog Colostethus undulatus, n. sp. has a glandular supracarpal pad atop the wrist, being best developed in males. This species, which also has the parasphenoid bone curiously concealed, seems to be unusual among tepui Colostethus in lacking the recently described median lingual process. The centrolenid frog $\mathrm{Hy}$ alinobatrachium eccentricum, $\mathrm{n}$. $\mathrm{sp}$. has a peculiar bicolored iris, with a dark median sector that conceals the pupil and which apparently dilates with the pupil. This character is retained in preservative and differentiates $H$. eccentricum from $H$. crurifasciatum Donnelly and Myers. Both species share a previously overlooked bubblelike structure in the web between the third and fourth fingers, herein termed bulla (possibly parasite induced?).
\end{abstract}

\title{
RESUMEN
}

El macizo Yutajé-Corocoro es una meseta de piedra arenisca muy erosionada, con un drenaje interno central dirigido hacia el valle del Río Corocoro, un tributario del Río Manapiare en sus cabeceras, situado a unos $100 \mathrm{~km}$ al este del Río Orinoco, en el extremo norte del Estado Amazonas, Venezuela. El suelo rocoso sustenta un mosaico de arbustales y bosques diversos, con pequeños herbazales tepuyanos en las zonas más altas. La herpetofauna del macizo está depauperada como es típico en un tepui en Venezuela.

Durante siete días en la temporada seca (febrero) se recolectaron ocho especies de anfibios y reptiles. La muestra incluye dos ranas nuevas (Hyalinobatrachium eccentricum, n. sp., Centrolenidae, y Colostethus undulatus, n. sp., Dendrobatidae) y un género nuevo de lagartijas (Adercosaurus vixadnexus, n. gen., n. sp., Teiidae) todos colectados en el bosque húmedo montano (a 1700-1750 msnm). También se encontró otra especie nueva de lagarto (Tropidurus panstictus, n. sp., Tropiduridae) en las zonas más bajas (180-1220 msnm), especialmente en los arbustales secos. 
La herpetofauna además incluye una rana de tierras bajas (Pseudopaludicola llanera Lynch), dos ranas tepuyanas (Eleutherodactylus cantitans Myers y Donnelly, E. yaviensis Myers y Donnelly), una lagartija tepuyana (Prionodactylus goeleti [Myers y Donnelly], n. comb.), una culebra (Liophis?) que escapó, y otra culebra (Thamnodynastes corocoroensis Gorzula y Ayarzagüena) colectada por S. Gorzula en 1987. Las dos especies de Eleutherodactylus y el Prionodactylus se encuentran también en el cercano Cerro Yaví (localidad tipo), aunque una de las ranas (E. yaviensis) y la lagartija son ligeramente diferentes. La culebra Thamnodynastes corocoroensis parece ser distinta de una especie relacionada del Cerro Yaví.

Dos de las especies nuevas presentan caracteres no descritos previamente. El dendrobátido Colostethus undulatus, n. sp. tiene sobre el dorso de la muñeca una almohadilla supracarpal glandular, más desarrollada en los machos, y tiene también el hueso paraesfenoides curiosamente escondido. Esta especie además difiere de los otros Colostethus tepuyanos porque carece del proceso lingual medial descrito recientemente. El centrolénido Hyalinobatrachium eccentricum, n. sp. tiene un extraño iris bicolor, con una parte central obscura que esconde la pupila y que aparentemente se dilata con ella. Este carácter se mantiene en el material preservado y sirve para diferenciar a $H$. eccentrium de la especie similar $H$. crurifasciatum Donnelly y Myers. Las dos especies también comparten un carácter no observado previamente que es una ampolla o burbuja, aquí denominada bulla, en la membrana entre los dedos manuales tercero y cuarto (posiblemente debido a parasitismo?).

\section{INTRODUCTION}

This is the second of three anticipated herpetology reports from the 1995 American Museum-TERRAMAR Expedition, which established helicopter-supported camps on several sandstone table mountains (tepuis) in headwater drainages of the Río Manapiaresome $100 \mathrm{~km}$ east of the middle Río Orinoco, between $5^{\circ}$ and $6^{\circ}$ North Latitude, in southwestern Venezuela. The first report (Myers and Donnelly, 1996) dealt with the fauna of Cerro Yaví, which has a small summit more than $2100 \mathrm{~m}$ above sea level. The present account deals with Cerros Yutajé and Corocoro, which together form a much larger but generally lower massif to the west of Cerro Yaví.

The Yutajé-Corocoro massif has received little attention from biologists. The summit of neighboring Cerro Yaví was explored in 1947 by the late William H. Phelps, Jr. and his wife Kathleen D. de Phelps, in company with Charles B. Hitchcock of the American Geographic Society. Hitchcock's report of the Phelps' expedition showed an aerial view of Cerro Yaví, with the "eastern cliffs of Serranía Yutajé" showing in the middle distance (Hitchcock, 1947: fig. 26 [reprinted in Myers and Donnelly, 1996: fig. 2B]). Although the existence of Cerro Yutajé was known to W. H. Phelps, Sr. and W. H. Phelps, Jr., they thought that it was too low to be of much ornithological interest (fide Kathleen D. de
Phelps, in conversation, 1995), and they made no plans to include it in their ambitious survey of the highland bird fauna of southern Venezuela (see Mayr and Phelps, 1967).

Several botanical collections were made on the Yutajé-Corocoro massif over a period of several decades, starting with work by Bassett Maguire in 1953 and ending with Otto Huber's expeditions in the late 1980 s (Huber, 1995b: 93). Huber was accompanied by Stefan Gorzula, who obtained several herpetological specimens. Gorzula and Señaris (1999: 255, 257) summarized this material as comprising one amphibian and two reptiles from $2150 \mathrm{~m}$ on Corocoro (November 8-12, 1987), and two reptiles from $1800 \mathrm{~m}$ on $\mathrm{Yu}-$ tajé (March 19-23, 1988). Included in Gorzula's collections was a new species of snake (Gorzula and Ayarzagüena, "1995" [1996]).

We here report on a collection of 117 specimens obtained by the 1995 AMNH-TERRAMAR Expedition during a 7-day period in the dry season (February 24-March 2). The collection contains eight species ( 5 frogs and 3 lizards), of which half are new. By including one snake seen but not caught, and the additional snake taken earlier by Gorzula, the known herpetofauna of the Yutajé-Corocoro massif consists of 10 species. As is characteristic of tepui environments, this is a depauperate fauna, although other species certainly wait to be found, especially in the wet season. 


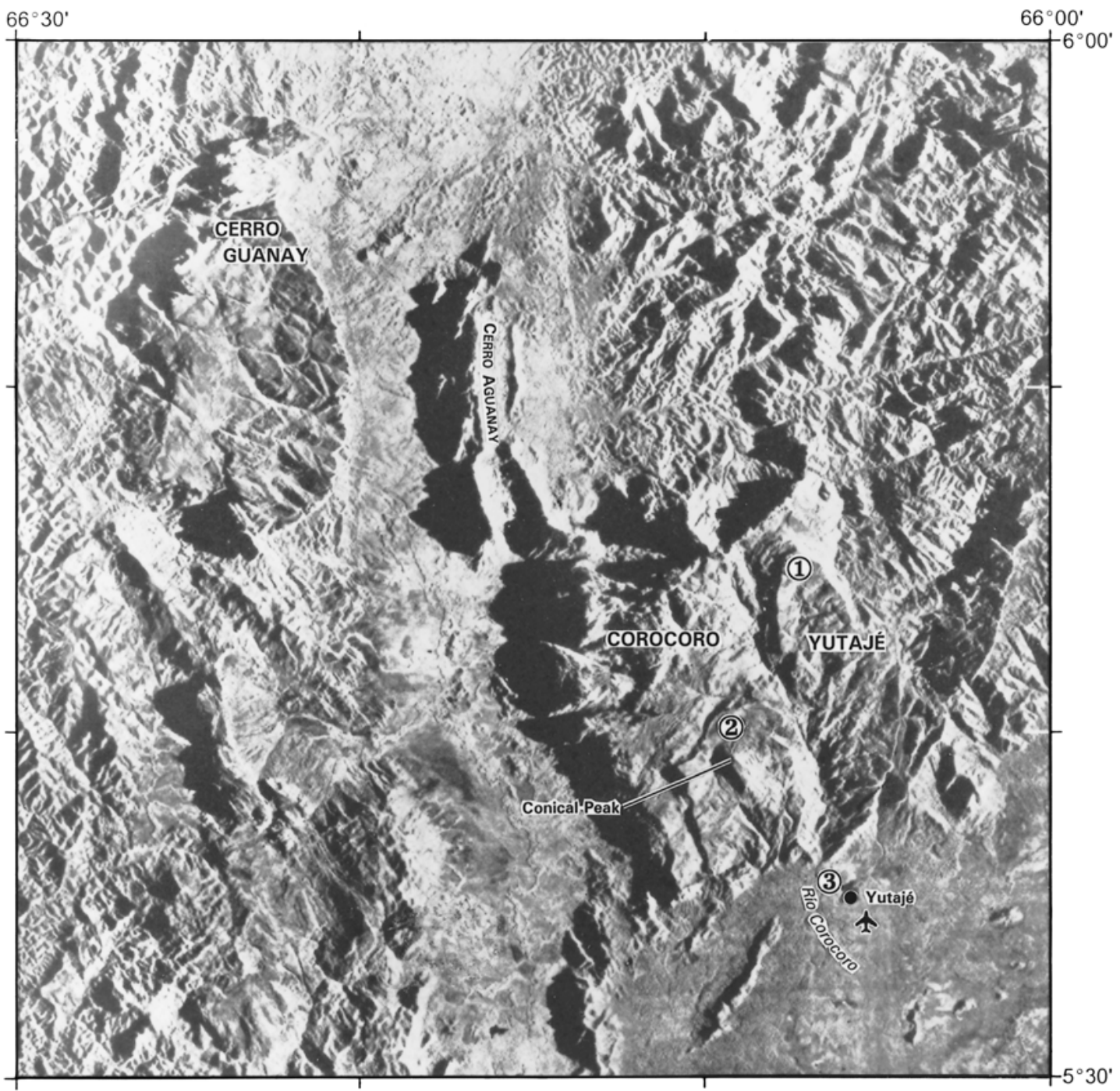

Fig. 1. Side-looking radar image showing the Yutajé-Corocoro massif. The names Cerro Yutajé and Cerro Corocoro apply to those parts of the massif lying to the east and to the west, respectively, of the upper valley of the Río Corocoro (see footnote 2 for synonyms). Neighboring Cerro Guanay is shown to the northwest; Cerro Yaví is off the map, about $28 \mathrm{~km}$ northeast of the landing field at Yutajé. Three collecting sites for the Yutajé-Corocoro massif are numbered as follow: 1. Cerro Yutajé camp at 1700 $\mathrm{m}$ elevation, on upper Río Corocoro, $5^{\circ} 46^{\prime} \mathrm{N}, 66^{\circ} 08^{\prime} \mathrm{W}$ (see figs. 6 [bottom], 7). 2. South end of Cerro Corocoro, $1220 \mathrm{~m}$ elevation, $5^{\circ} 42^{\prime} \mathrm{N}, 66^{\circ} 10^{\prime} \mathrm{W}$, near prominent conical peak (see figs. 4, 5). 3. Head of dugout navigation on Río Corocoro, above Yutajé, a fishing camp at $180 \mathrm{~m}$ elevation, $5^{\circ} 37^{\prime} \mathrm{N}, 66^{\circ} 07^{\prime} \mathrm{W}$.

The coordinates above were determined by GPS satellite receivers. However, positions of the numbered collecting localities are placed on this radar image from helicopter and ground observation and with reference to other topographic maps (see text) - the published map coordinates for this image are accurate to only $02^{\prime}$. (From sheet NB-19-12, 1:250,000, elaborated by International Aero Service Corporation and published by Comisión para el Desarrollo del Sur de Venezuela [CODESUR], Ministerio de Obras Publicas, Venezuela, 1971.) 

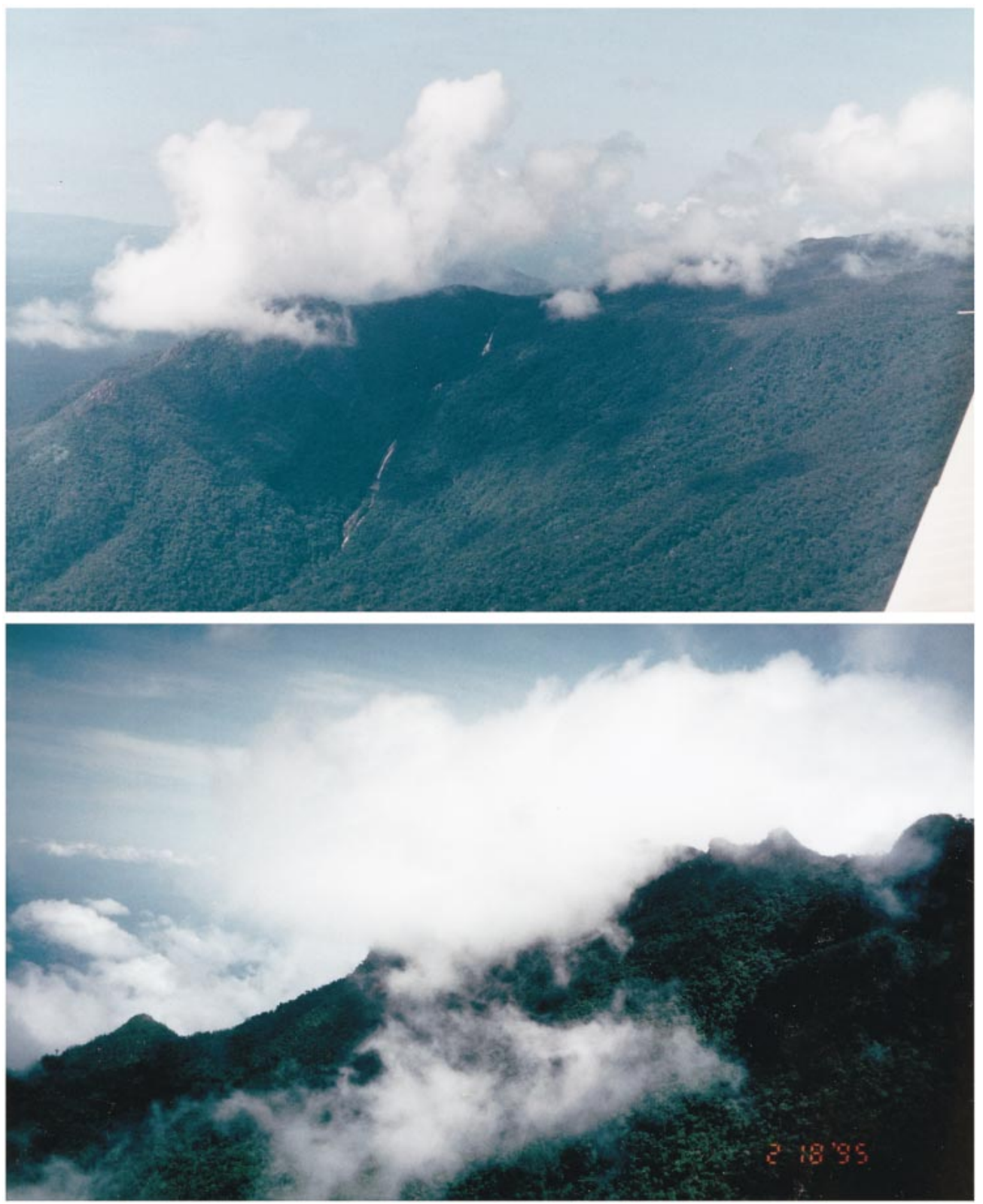

Fig. 2. Outer perimeters of the Yutajé-Corocoro massif, as viewed from the air. Top: The southern slope from small plane reconnaissance, on September 17, 1994. Bottom: Cerro Corocoro at the high northwestern side of the massif, from a helicopter on February 18, 1995.

\section{MATERIALS AND METHODS}

Deposition of Specimens: Contractual agreements with PROFAUNA and INPARQUES provided that one-half of our collection, including all holotypes and half of the species represented by single specimens, would be cataloged in the collection of the Museo de la Estación Biológica de Rancho Grande (EBRG) in Maracay, with the other half going to the amphibian and reptile collections of the American Museum of Natural History 

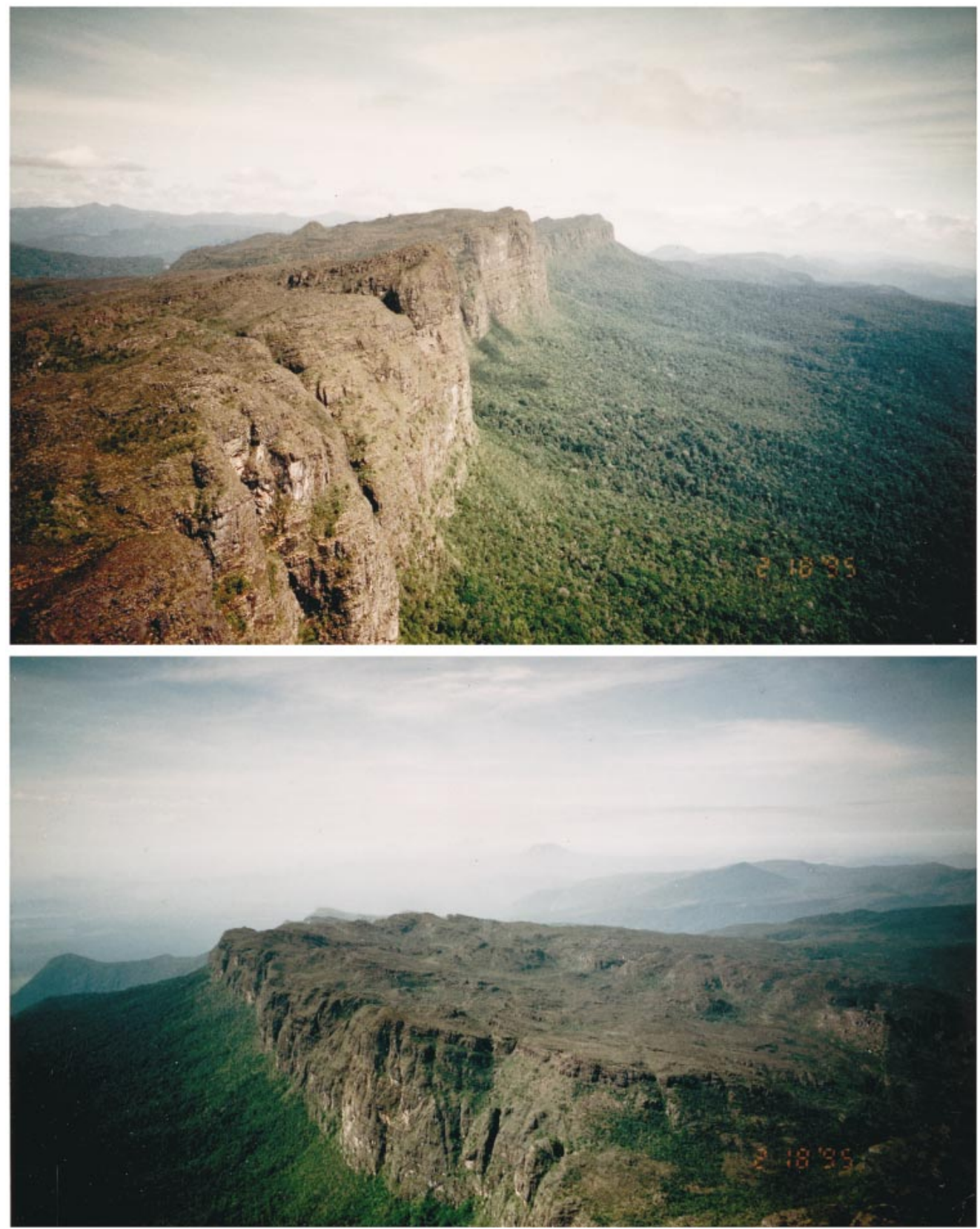

Fig. 3. The eastern escarpment of Cerro Yutajé, as viewed from a helicopter (February 18, 1995). Top: Looking northward along the eastern rim on approach to Cerro Yutajé. Bottom: Looking southward along the rim while leaving Cerro Yutajé. Visible landmarks in the lower photograph include (1) Cerro Camani on horizon, right of center, and (2) farther to the right but closer, the prominent small conical peak on the southern end of the Corocoro portion of the Yutajé-Corocoro massif (see figs. 1, 4, 5). 
$(\mathrm{AMNH})$ in New York. We thank Francisco J. Bisbal, Director of the EBRG Museum, for facilitating the cataloging process and for helping in other ways.

Most specimens were collected by a herpetology team comprised of ourselves and John Daly, but, as was commonplace in the camps of this expedition, obliging colleagues of every discipline lent a hand. All material is cataloged as having been collected by the 1995 AMNH-TERRAMAR Expedition-an abbreviation for the official name "The Robert G. Goelet American Museum-Terramar Expedition to the Northwestern Tepuis".

Methods: Insofar as practical, we find it useful to follow Ruiz-Carrenza and Lynch's (1991a, 1991b et seq.) standardized format for definitions and descriptions of centrolenids, and Lynch's long-term format and methodology for eleutherodactyline leptodactylids (best summarized in Lynch and Duellman, 1980, 1997). For anuran webbing formulae, we use the increasingly common notational device of Savage and Heyer (1967) as modified for general use by Myers and Duellman (1982: 6); see also Myers et al. (1991: 6) regarding the desirability of using this convention for dendrobatids. Tadpoles were staged according to Gosner (1960). Measurements of less than $12 \mathrm{~mm}$ were taken with an ocular micrometer fitted in a Wild dissecting microscope; larger measurements were made with digital calipers or a ruler read to the nearest 0.1 or $1 \mathrm{~mm}$, depending on size. Sound spectrographs and waveforms were produced using a Kay 5500 DSP SonaGraph.

In the field, coordinates were determined by two hand-held Global Positioning System (GPS) satellite receivers. We rounded readings to the nearest minute of latitude and longitude. ${ }^{1}$ Our receivers always were in agreement to the nearest minute, but GPS at that time was particularly untrustworthy for elevation, which therefore was determined

\footnotetext{
${ }^{1}$ Readings to seconds or to minutes with decimal notation would have given a false sense of precision at that time. Prior to May 2000, point-position accuracy of civilian GPS devices was limited (for military reasons) "to about $100 \mathrm{~m}$ by reducing the accuracy of the broadcast ephemeris, altering the clock epoch, and dithering the clock frequency, thus affecting both code-correlating and codeless receivers" (Dixon, 1991: 252).
}

mainly by a Lufft pocket altimeter (20-m graduations). On two occasions, the altimeter was set at the known elevations of different airports near Caracas (about 9 a.m. each time), and subsequent readings were taken at the Yutajé base-camp landing field. An elevation of $180 \mathrm{~m}$ was accepted for the landing field at Yutajé based on these readings (September 16, 1994: $210 \mathrm{~m}$ on arrival at 2 p.m., but $180 \mathrm{~m}$ at 7 a.m. the following morning; February 4, 1995: $180 \mathrm{~m}$ on arrival at 11:45 a.m.). Because of daily fluctuation in atmospheric pressure, a morning reading was chosen when possible. Elevations recorded for our two main collecting sites were about 200 $m$ lower than shown on a topographic map (see Collecting Sites below).

\section{THE NATURAL LANDSCAPE}

The Yutajé-Corocoro massif is a highly eroded sandstone mountain on which most of the drainage flows inwardly to the central valley of the Río Corocoro, which runs southward to exit the southern edge of the massif near Yutajé, a fishing camp and earthen landing field (fig. 1). The southern side of the massif (fig. 2, top) is comprised of steeply forested slopes with several prominent waterfalls that have greatly reduced flows in the dry season. The western side of the massif (fig. 2, bottom) often was obscured by clouds during our brief overflights, but it is much more steeply sloped than the southern side, and there are some noncontinuous vertical cliffs marking parts of its upper edge. The eastern side is guarded by vertical cliffs, giving an appearance more in keeping with the common perception of tepui landforms (fig. 3).

The high and often jagged northern periphery drops very sharply into a low rugged system of ridges and hills (fig. 1), with the northern base of the massif being higher than the low (roughly $200 \mathrm{~m}$ ) southern base. Some of this complicated ridge system forms a narrow connection between the northeastern base of Cerro Yutajé and the northern base of Cerro Yaví, an otherwise isolated tepui having a small summit entirely above $2100 \mathrm{~m}$ (Myers and Donnelly, 1996). Except for the broken country beyond its northern and northeastern side, the Yutajé-Corocoro massif is bordered by lowlands $(180 \mathrm{~m}$ at 
Yutajé) supporting a mosaic of savanna and forest. Fires in the dry savannas near Yutajé were visible one night from our camp at $1700 \mathrm{~m}$, in the upper drainage of the Río Corocoro.

The northern edge of the Yutajé-Corocoro massif extends irregularly from east to west along the southern border of Bolívar State, with the greatest part of the massif protruding southward into the northern part of Amazonas State. The highest elevations according to Huber (1995a: 43, 47) are $2140 \mathrm{~m}$ near the northeast edge of Cerro Yutajé, and 2400 $\mathrm{m}$ in the northwest corner of Cerro Corocoro, but the southern three-fourths of the massif lies mostly below $1700 \mathrm{~m}$. Huber (1995a: 43) estimated the entire summit area as $275 \mathrm{~km}^{2}$.

There is no reason other than convention for not using a single name for the whole massif, which our party in the field simply called "Cerro Yutajé". The names Cerro Yutajé and Cerro Corocoro seem to be old designations for the high parts of the massif on its northern perimeter. Each name also has been vaguely conjoined with Serranía, either as separate or synonymous entities (e.g., "Serranía Yutajé o Corocoro" [Hitchcock, 1947: pl. 2]). Huber (1995a: 43, 47 [map]) extended the names Yutajé and Corocoro southward to include all of the two inwardly "inclined summit plateaus" drained mainly by the Río Corocoro (Río Yutajé), and we follow his usage here as a practical solution. ${ }^{2}$

\footnotetext{
${ }^{2}$ Cartographic Nomenclature: We follow older maps, and also Gorzula (in Gorzula and Ayarzagüena, "1995" [1996], and Gorzula and Señaris, 1999), in using the orthography Corocoro, which Huber (1995a, 1995b, 1995c) consistently rendered "Coro Coro" without explanation.

For the major stream exiting the south side of the Yutajé-Corocoro massif, we employ the name Río Corocoro simply because it is the name used by local people at the Yutajé base camp. In this sense, Río Corocoro is synonymous with Río Yutajé of some maps and authors. To confuse matters more seriously, two official government maps use Río Maniapure for the major stream draining the Yutajé-Corocoro massif, and they assign the names Caño Yutajé and Caño Corocoro to two other streams - tributaries that exit the massif to the east and to the west, respectively, of the "Maniapure", before joining the larger stream either below or above (respectively) the landing strip at Yutajé (1:100,000 topographic sheets 6932 [Guaviarito] and 6933 [Serranía de Guanay], published by Servicio Autónomo de Geografía y Cartografía Nacional in 1988 and 1990).
}

Hitchcock's (1947) map showed Caño Yutajé as in the
The summit of the massif drops generally southward (fig. 4), as well as inward, but the landscape is very irregular. A small conical peak near the southern end of Cerro Corocoro forms an important landmark by which accuracy of map coordinates could be judged; the conical peak is identifiable in figure 1 and is seen in this paper in various aerial views (see below under Collecting Sites). The sandstone base of the massif is frequently exposed (e.g., fig. 5, top). At elevations of 1220 and nearly $1700 \mathrm{~m}$, glimpses were had along stream banks of displaced blocks (at $1220 \mathrm{~m}$ ) or of a stratum of coarse conglomerate containing cobbles of sandstone or quartzite (fig. 5, bottom). Conglomerate is a rare type of rock among the sandstones and quartzites of the Roraima Formation. It seems likely to be the same conglomerate that occurs at similar elevations on neighboring Cerro Yaví. (During their ascent of Yaví in 1947, the Phelps Expedition found interbedded conglomerates and sandstones between 4840 and $6000 \mathrm{ft}$ [1476-1829 m], ${ }^{3}$ with conglomerates becoming rare above $6000 \mathrm{ft}$ [Hitchcock, 1947: 561-562].)

The rocky soil of the Yutajé-Corocoro massif supports varied plant associations, as briefly mentioned by Huber (1995a: 43; 1995c: $124-125,135,153)$. There seem to be no grasslands. The tepui meadows mentioned by Huber (1995c: 153) are of his broad-leaved, nongramineous type dominated by Kunhardtia rhodantha. We did not encounter such meadows on the Cerro Yutajé side of the massif, but they are common on the higher parts of Cerro Corocoro. Huber

government maps above, but it used a different name (Río Manapiare) for the main stream. All these streams and many more form the headwaters of the Río Manapiare (an established name), itself a major tributary of the more southern Río Ventuari (also an established name). Instability in riverine nomenclature is mainly a phenomenon of unpopulated or sparsely populated headwaters, where boats cannot go far and where the cartographer's pen is unhindered by established tradition.

${ }^{3}$ The metric system is used in a Spanish translation (Hitchcock, 1948: 174-175), in which 4840 and 6000 feet are inexplicably converted to 1900 and $2000 \mathrm{~m}$. Similar departures from Hitchcock's original elevations (vs. distances) occur throughout the translation (by W. H. Phelps, Jr.). The differences are too great for rounding errors, leading one to wonder whether corrections were intended. 

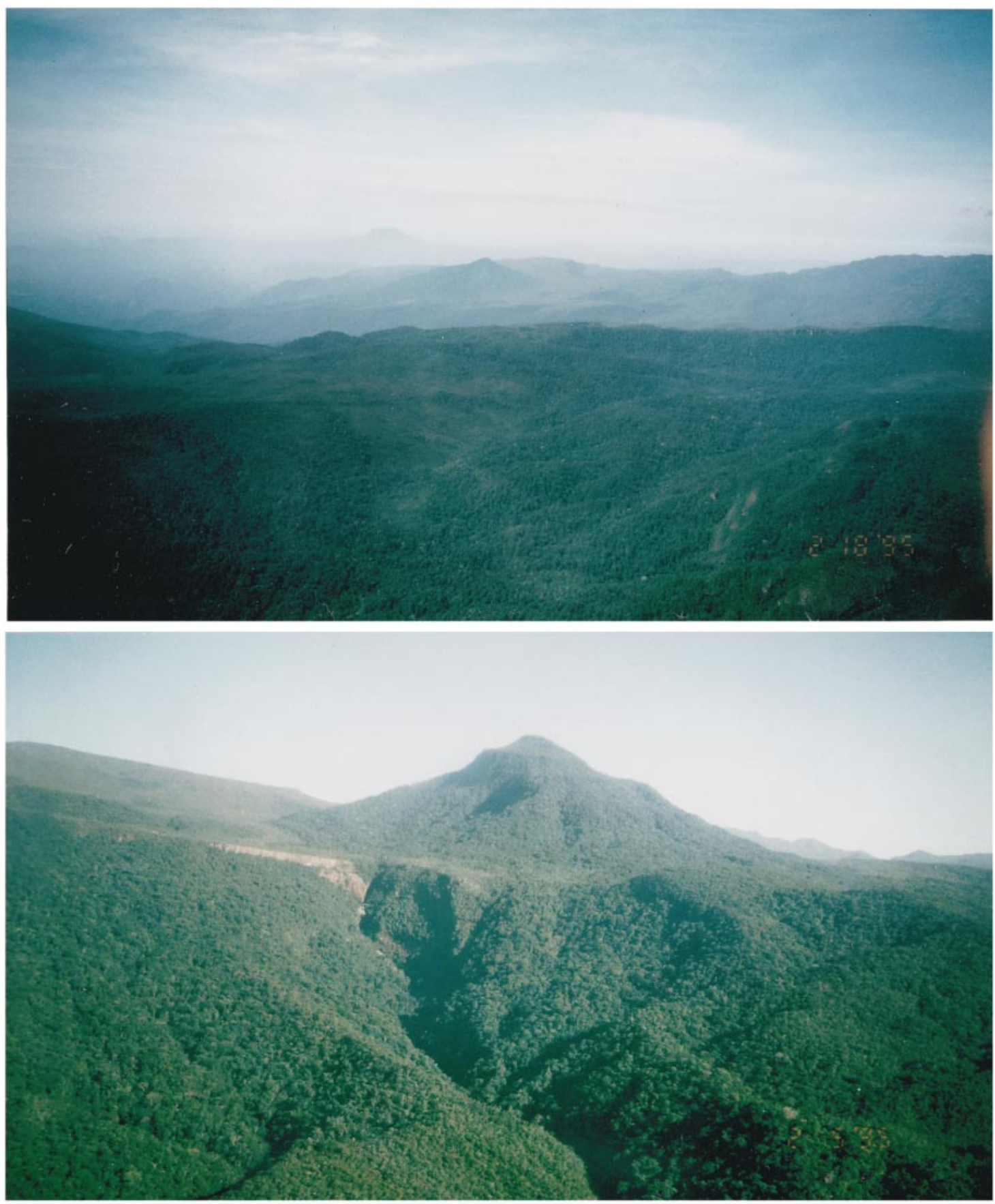

Fig. 4. Top: Helicopter view from the north-central part of the Yutajé-Corocoro massif, looking southward over the massif to Cerro Camani on the far horizon (February 18, 1995). The closer small conical peak is on the southern end of Cerro Corocoro; it is a constant landmark. Bottom: Approaching the conical peak seen above, still looking southward over the eroded interior of the Yutajé-Corocoro massif (February 5, 1995). See figure 1 for orientation. 

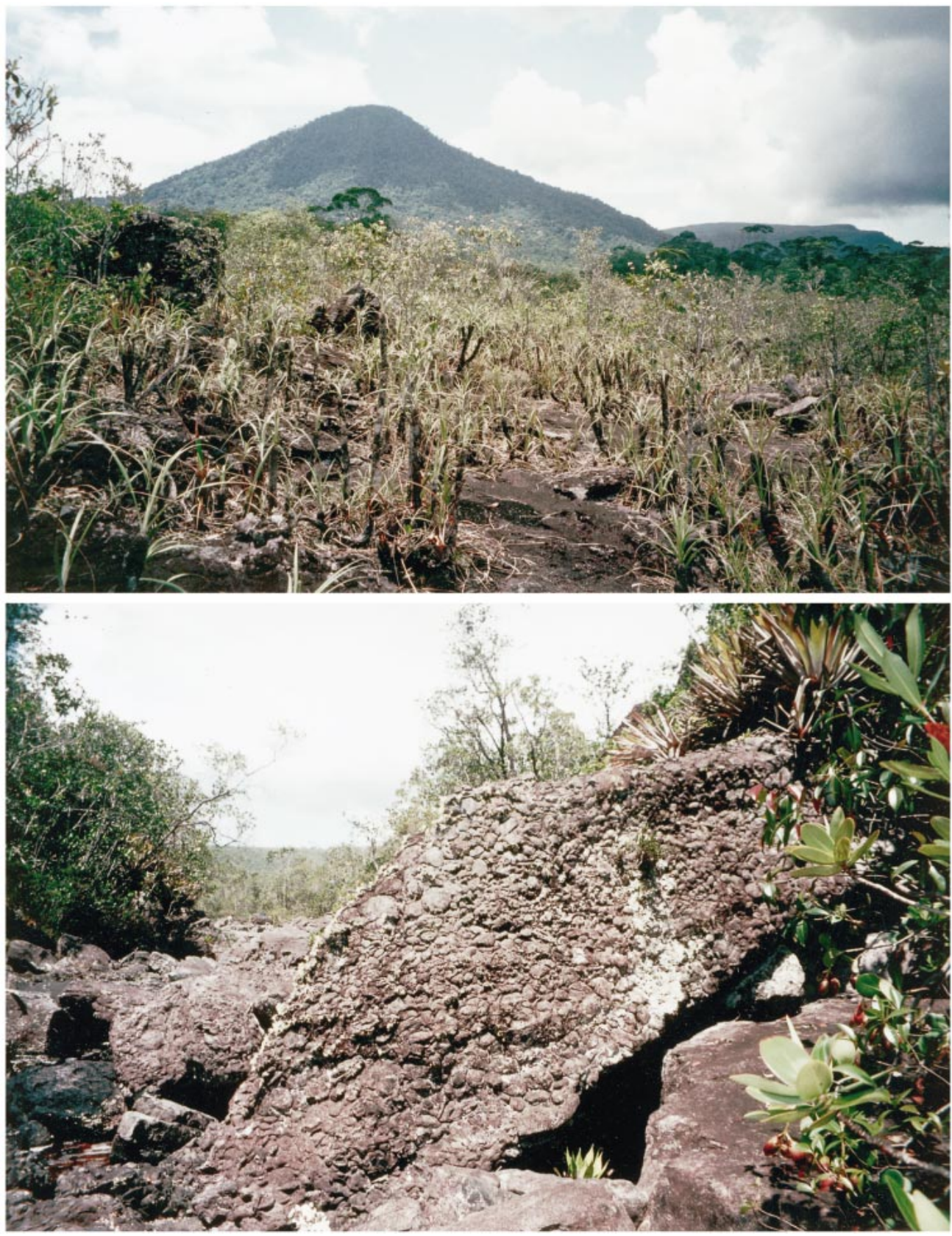

Fig. 5. Top: Small plateau, $1220 \mathrm{~m}$ elevation, just north of the conical peak (see also fig. 4). The habitat is hot, open scrubland, with frequent areas of bare rock. The numerous dark stems with terminal rosettes are the peculiar Vellozia tubiflora (Velloziaceae). This area, including an adjacent, rocky ravine (see below), is the type locality of the lizard Tropidurus panstictus. Bottom: Rocky stream bed (lower left) near the base of the conical peak shown above, habitat of Pseudopaludicola llanera and Tropidurus panstictus. Note the large block of sandstone conglomerate. (February 28, 1995) 
described one Kunhardtia meadow at 1850 m elevation on Cerro Yutajé, and we landed briefly in another at $1910 \mathrm{~m}$ in the high northwestern side of Cerro Corocoro (fig. 6, top). Kunhardtia-dominated meadows and wet slopes are a major habitat at least on the high slopes of Cerro Corocoro, but we unfortunately lacked time to establish a camp or to collect in them.

Scrubland (Huber, 1995c: 135) covers much of the massif, and we collected in two diverse types of scrub (fig. 5, top, and figs. $7,8)$. The extensive scrublands of the Yutajé-Corocoro massif are broken by areas of forest, which Huber (1995c: 124-125) divided into three types: (1) basimontane, semideciduous forest below $500 \mathrm{~m}$ on southern slopes; (2) dense, medium-sized, submontane to montane evergreen forest below $1500 \mathrm{~m}$ in the ascending interior uplands; and (3) dense, low-sized, wet, evergreen upper montane forest, above approximately $1500 \mathrm{~m}$. We collected only in the last type of forest-a wet mossy forest-which seems to occur especially in low areas near the highland streams (figs. 6, 7, 23); it is an important habitat for some amphibians and possibly for a few reptiles as well.

\section{Collecting Sites}

We collected at three places on the YutajéCorocoro massif, as shown in figure 1, which requires comment. The side-looking radar image reproduced herein as figure 1 is presumably the one used for Huber's (1995a: 47) sketch map. The coordinates shown in our respective renditions of this map give a false impression of geographic precision, which was initially puzzling to us in the field. Our problem was that the old radar image is accurate to only $02^{\prime}$, as stated on a later adaptation of the image. ${ }^{4}$ The map inaccuracy is reflected both in longitude and in parallels of latitude, as is most evident for locality 2 (figs. 4, 5 [top]) - a small plateau at the northern base of the small conical peak that is readily identified on the map.

\footnotetext{
${ }^{4}$ Sheet NB-19-12, 1:250,000, Picto Radar, produced by the Dirección de Cartografía Nacional in 1982, from the 1971 Mosaico de Radar (see fig. 1), with the added qualification that geographic precision is on the order of $02^{\prime}$.
}

If our localities were plotted on figure 1 by use of the GPS coordinates, locality 2 would lie too far west and also well north of the southwestward running escarpment that nearly isolates the little plateau from which the conical peak rises. Our locality 1 (arrow in fig. 6 , bottom) also would be shown too far west and too far north. Furthermore, Huber and Gorzula's 1987 camp on Cerro Corocoro would lie outside of the summit area if plotted on the outline map in Huber (1995a: 47). ${ }^{5}$

The following three collecting sites were therefore placed in figure 1 by ground and helicopter observation, in conjunction with GPS coordinates referenced to available topographic maps $(1: 100,000$, sheet 6932 [Guaviarito], 1988, and sheet 6933 [Serranía de Guanay], 1989, Servicio Autónomo de Geografía y Cartografía). These maps show localities 1 and 2 as being 180-220 m higher than our altimeter readings, but there is no guarantee of accuracy (map contours were derived from aerial photographs taken 30 years ago, with few ground checks).

Locality 1: Cerro Yutajé campsite on a branch of the upper Río Corocoro (GPS coordinates $\left.5^{\circ} 46^{\prime} \mathrm{N}, 66^{\circ} 08^{\prime} \mathrm{W}\right), 1700 \mathrm{~m}$ by altimeter (about $1920 \mathrm{~m}$ on sheet 6933, 1: 100,000). Camp consisted of a streamside kitchen shelter, with tent sites scattered about in the adjacent forest. Some woody branches along the stream were removed so the helicopter could safely land in the stream bed with a full load. ${ }^{6}$ Although the gorge of the Río Corocoro forms a major north-to-south break in the Yutajé-Corocoro massif, the river at $1700 \mathrm{~m}$ and above is shallow and not entrenched. The stream is a clear coffee color and flows over a bed of sandstone. A fresh vertical exposure at camp is of a fine-grained sandstone of thin, alternating pink and white strata. Several members of our party who worked their way downstream from camp commented on a thick stratum of sandstone conglomerate interbedded between sand-

\footnotetext{
${ }^{5}$ GPS coordinates and elevations for Huber and Gorzula's 1987-1988 camps were given by Gorzula and Señaris (1999: 255, 257 [localities H-017 and H-052]).

${ }^{6}$ There was no extensive clearing of vegetation. Conscientious attempts were made in this and all other camps to remove all garbage by helicopter. We hope that any traces of our presence are few and transient.
} 
stone-similar to the displaced blocks of conglomerate seen in another stream at locality 2 (fig. 5, bottom). Although there was a sharp drop in the river below camp (notice the entrenchment in lower right of fig. 6, bottom), the river upstream is open and provides an easy highway through dense vegetation. A short walk upstream, to an elevation of about $1750 \mathrm{~m}$, brought one to a tributary entering on the east bank. A new species of Colostethus was common here, although it appeared to be completely absent in the forest downstream across from the 1700-m camp, even though the habitat was continuous.

The upper Río Corocoro is a mosaic of scrub and wet mossy forest (fig. 6, bottom). Near camp, the rocky slopes on the western side of the river support a dense scrub of small trees (Tyleria may be dominant; Clusia and a few palms are also present), Brocchinia, and Stegolepis (figs. 7, 8).

In great contrast to the dense, sun-exposed scrub on the west bank, a low wet forest parallels the river along its eastern side (see fig. 6 , bottom). This narrow strip of forest contains its own small tributary streams, canopycovered and with sediment, in contrast to the open, scoured bed of the nearby river. There is abundant leaf litter in the forest and large bromeliads on the ground and in the trees, which bear a conspicuous moss layer reminiscent of cloud forest. As inferred from figures 6 (bottom) and 7 (top), this mossy forest is continuous with similar forest upstream along the Río Corocoro (fig. 23).

The wetness of the mossy forest results from not only local peculiarities of drainage, but also from air currents that ascend the valley and bring orographic rainfall to this part of the massif. Streams were drying out during February on the southern part of the massif, the grass turned brown at the Yutajé base camp, and fire was being set to the nearby savannas. On a clear night, the burning savannas were visible perhaps $20 \mathrm{~km}$ or farther from our highland camp (which was $17 \mathrm{~km}$ airline north of Yutajé).

Although it clearly was dry season below, daily rainfall was recorded at the 1700-m camp by both groups who worked there from February 11 through March 1. Light or heavy, the montane rain came every day dur- ing early or midafternoon. On March 1 (our last night in camp), rainfall upstream from camp was particularly heavy, causing the river to rise alarmingly by dusk. Camp activities were disrupted and foot travel along the river was difficult. The next morning, on very soggy ground, Paul Sweet picked up the only known specimen of a new genus and species of lizard.

Locality 2: South end of Cerro Corocoro (GPS coordinates $5^{\circ} 42^{\prime} \mathrm{N}, 66^{\circ} 10^{\prime} \mathrm{W}$ ), $1220 \mathrm{~m}$ (about $1400 \mathrm{~m}$ on sheet 6933), on small plateau with an incised streambed, $2.9 \mathrm{~km}$ (airline) due north of the conical peak that is a prominent landmark on the southern side of the massif. The area was examined by smallplane reconnaissance in September 1994, but the locality was too low for the single camp to be established on the Yutajé-Corocoro massif. We visited this site by helicopter from the 1700-m camp; locality 2 was worked for several hours on February 28 and again on February 29, 1995. The only herpetological specimens collected or seen were the frog Pseudopaludicola llanera and a new species of the lizard genus Tropidurus.

The little plateau supports a dry scrub that is very different and much more open than the scrubland at locality 1 . The openness must be largely due to thin soil and the frequent exposure of sandstone at ground level (fig. 5, top). The dominant vegetation includes a low stratum of Vellocia tubiflora, Stegolepis, and Brocchinia, and a sparse growth of small trees, especially Tyleria.

There is a very narrow strip of gallery forest on the plateau along a small incised stream, in which little water was flowing in late February. The streambed is full of sandstone blocks and boulders, as well as large, displaced blocks of conglomerate (fig. 5, bottom) such as seen in situ below the 1700-m camp. As mentioned earlier, conglomerate is an unusual rock in the Roraima Formation.

Locality 3: Río Corocoro above Yutajé, $180 \mathrm{~m}$ (GPS coordinates for Yutajé, 5³7'N, $66^{\circ} 07^{\prime} \mathrm{W}$ ). This locality (El Salto on sheet 6932) is about 15 minutes by motorized dugout upstream from Yutajé and cannot be missed, since it is the head of navigation at the southern base of the Yutajé-Corocoro massif. It is an area of forest with some open rocky slopes. Considering the drainage area 

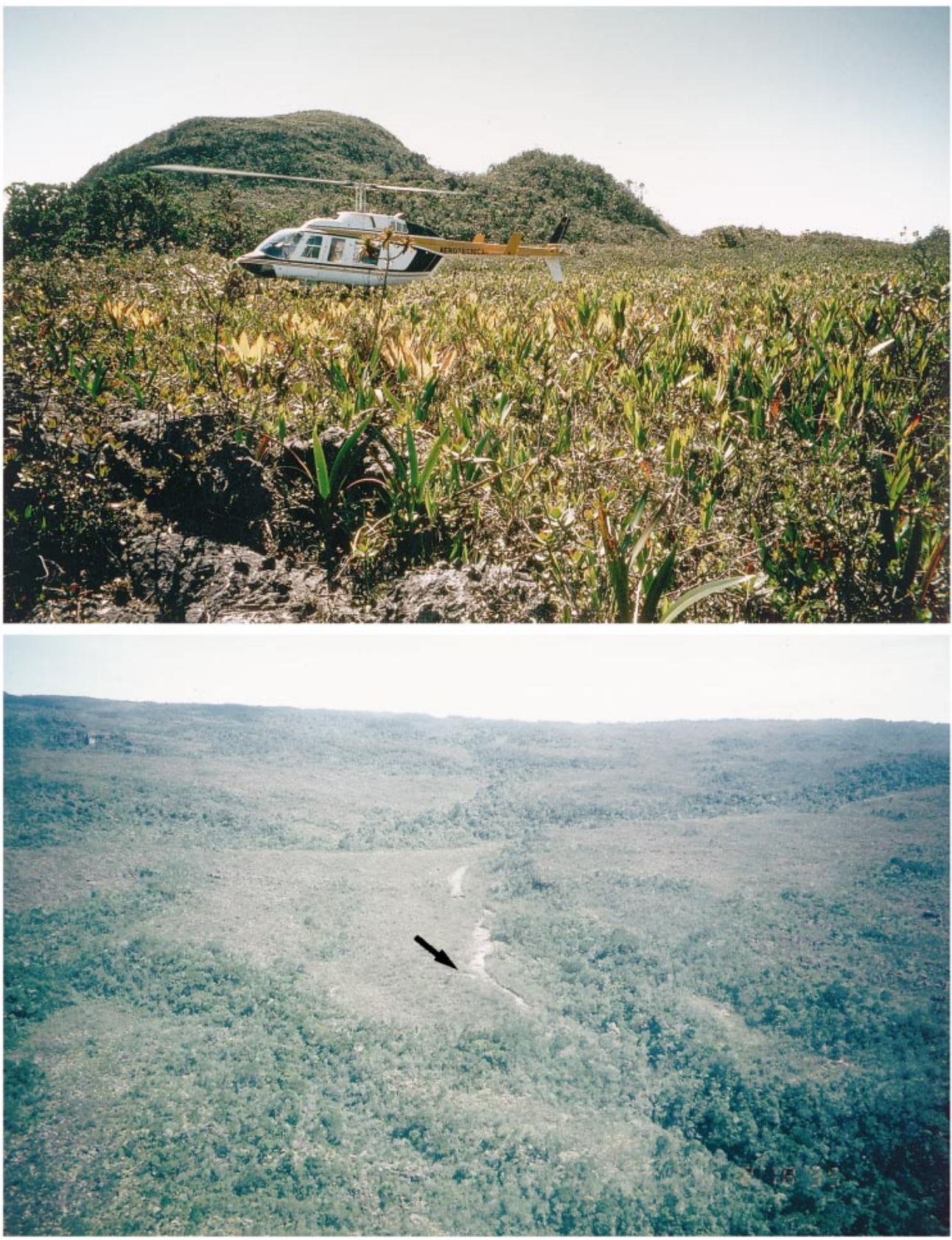

Fig. 6. Top: A broad-leaved (nongramineous) tepui meadow on Cerro Corocoro, $1910 \mathrm{~m}$ above sea level, in the high northwestern quadrant of the Yutajé-Corocoro massif. The dominant plants are Kunhardtia (Rapateaceae), with green straplike leaves, and Brocchinia (Bromeliaceae), the broader, yellowish-leaved tank bromeliads, all growing on a sphagnum substrate (February 14, 1995). Bottom: Helicopter view near the northern edge of Cerro Yutajé, looking northward over upper headwaters of the Río Corocoro, showing scrubland with interspersed forest (February 18, 1995). The arrow indicates a campsite at $1700 \mathrm{~m}$ above sea level. The forest edge across the stream from camp is the type locality of the lizard Adercosaurus vixadnexus. East of camp, paralleling the open main stream, a strip of dense, mossy gallery forest marks the course of a small woodland brook, the type locality of the frog Hyalinobatrachium eccentricum. The type locality of the frog Colostethus undulatus is situated farther upstream in this gallery forest, at about $1750 \mathrm{~m}$ elevation (see fig. 23). 

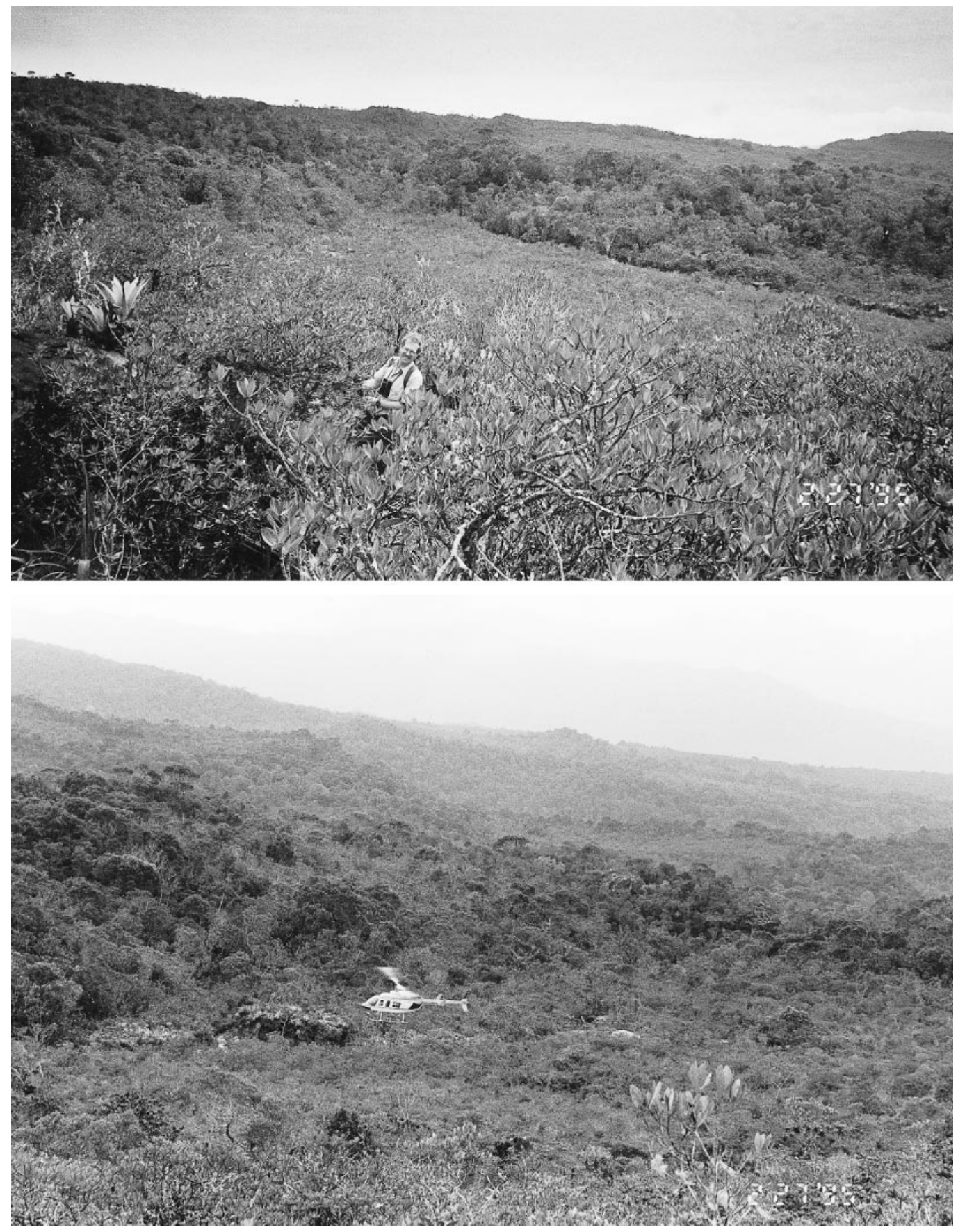

Fig. 7. Views of the upper Río Corocoro valley, from the slope above the 1700-m camp (see arrow in fig. 6, bottom). Top: Looking northeastward (upstream) toward the Colostethus locality on far side of river. Bottom: Looking southeastward to helicopter about to sit down in the streambed at camp.

The hillside above the 1700-m camp is covered in Tyleria-Stegolepis-Brocchinia scrub growing on rocky soil. Peering uphill (looking for the cameraman who had just called to him), ornithologist George Barrowclough provides a sense of scale for the density and height of the scrub vegetation. See figure 23 for interior views of the mossy gallery forest across the river. 


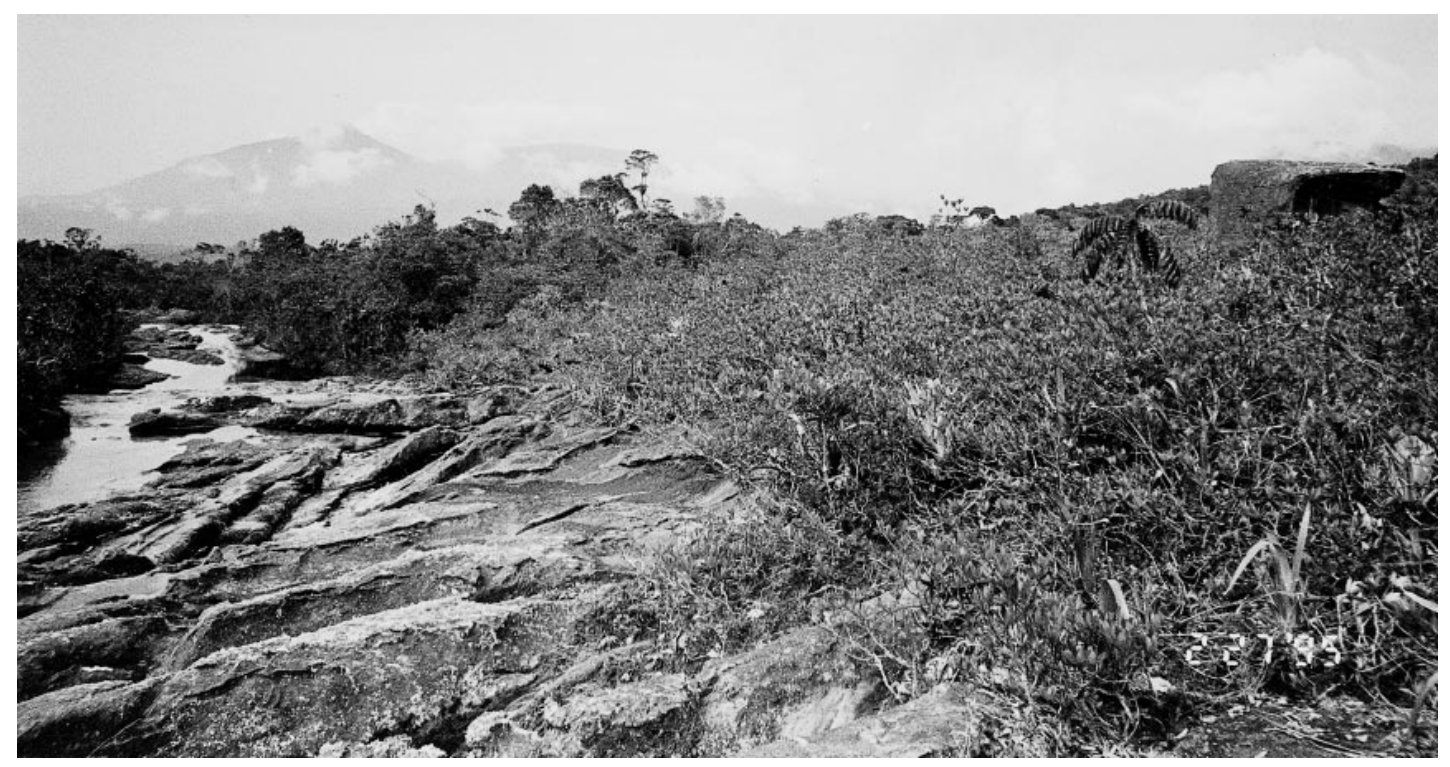

Fig. 8. Looking southward down the upper Río Corocoro toward direction of the 1700-m camp, a short distance below the 1750-m Colostethus locality. The open, scoured streambed, flanked here by rocky scrubland on the west bank, is in stark contrast to the small woodland streams in dense, mossy forest on the eastern side of the valley (for overviews, see figs. 6 [bottom], 7; for interior of mossy forest, see fig. 23).

involved, the Corocoro seems in the dry season to be a small river, although it can become torrential. There are low falls over hard sandstone or quartzite that has a colorful water-polished surface. The rocky channel is well scoured, although there are small pockets of the characteristically fine, white Roraima sand. The place is used as a swimming hole by visitors to Yutajé. Only Tropidurus was collected at this locality (on March 2, 1995).

\section{SPECIES ACCOUNTS FROGS}

FAMILY CENTROLENIDAE

\section{Hyalinobatrachium eccentricum, new species \\ Figures 9-12,13B, 13C, 14}

Holotype: EBRG 3049 (field no. CWM 19713), an adult male from waterfall in small forest stream on Cerro Yutajé, $1700 \mathrm{~m}$ $\left(5^{\circ} 46^{\prime} \mathrm{N}, 66^{\circ} 08^{\prime} \mathrm{W}\right)$, Amazonas, Venezuela; collected February 26, 1995, AMNH-TERRAMAR Expedition. See locality 1 on map (fig. 1)
PARATOPOTYPE: AMNH 159164 (CWM 19712), an adult male with same collecting data as holotype.

ETYMOLOGY: The species name is a Latin adjective meaning "not concentric", in allusion to the unconventional elliptical to domelike shape of the median part of the iris.

Definition ANd Diagnosis: A Hyalinobatrachium belonging to the fleischmanni species group and characterized by the following combination of characters (in the format of Ruiz-Carranza and Lynch, 1991b, with unusual characters in italics): (1) Vomerine teeth absent; (2) bones white in life; (3) parietal peritoneum clear; liver, stomach, and intestines, and a variable part of pericardium, silvery white, but gallbladder exposed; (4) in life, head and dorsum with pale green or pale yellow spots set in a light green reticulum dotted with dark green-changeable to pure green with green dots; hind legs with narrow, faint green crossbars; in preservative, spots and limb bands lost, dorsum becoming cream with purplish black melanophores; iris bicolored, with a brown circumpupillary zone concealing pupil (pupillary ring absent) and 
a golden yellow peripheral zone with gray flecks; (5) webbing absent between inner fingers; webbing formula for outer fingers III 2-2 IV_- a bulla in outer-finger webbing; (6) webbing formula for foot I 2-2 II 1 1 $1 \frac{2-2}{2}$ III $1 \frac{1 / 2}{2}-\left(2-2^{1 / 2}\right)$ IV $\left(2-2 \frac{1}{2}\right)-1 \mathbf{V}$; (7) snout truncate in dorsal and lateral views; (8) dorsal skin smooth in preservative; (9) very weak ulnar and tarsal folds arguably present; (10) humeral spine absent; (11) tympanum covered by skin (visible through skin); (12) size medium, males about 21-23 mm SVL, females not known; (13) nuptial excrescence present as small patch of gland cells on dorsomedial base of thumb, continuing proximally along thenar tubercle.

In general morphology and colorationincluding presence of a bulla in the outerfinger webbing (fig. 12) and narrowly crossbanded legs in life (fig. 9)-Hyalinobatrachium eccentricum closely resembles $H$. crurifasciatum Myers and Donnelly, but eccentricum is immediately separated by its bicolored iris. The median dark zone surrounding and concealing the pupil (which lacks the usual bright pupillary ring) is diagnostic even in preservative (fig. 13).

Measurements of Holotype and ParaTOPOTYPE (in $\mathrm{mm}$ ): Both undissected specimens are adult males as revealed by presence of vocal slits and distensible, subgular vocal sacs. The following measurements are for the holotype first, paratopotype second: SVL 21.6, 22.9; tibia length 10.5, 11.4; foot length from proximal edge of inner metatarsal tubercle to tip of longest toe 9.6, 9.7; head width $8.6,8.9$; greatest body width $9.3,9.4$; head length on the diagonal from angle of jaw to tip of snout $6.4,6.4$; upper eyelid width 1.4, 1.3; interorbital distance 2.9, 3.0; eye to posterior edge of nostril 1.8, 1.9; eye length 2.9, 2.9; tympanum not well defined, about 1.0, 1.0; width of fourth finger disc $1.4,1.4$; width of third toe disc 1.0, 1.2; width of fourth toe disc 1.3, 1.4.

\section{DESCRIPTION}

The two specimens in the type series are moderate-sized adult males, falling within the range of 21-23 $\mathrm{mm}$ SVL. See above for measurements.

MORPHOLOGY: Head slightly narrower than body; head width 39-40\% of SVL. Snout short, truncate in dorsal view and in profile; end of snout nearly vertical in profile or (in holotype) with a slight posterodorsad inclination; canthus rostralis indistinct; loreal region sloping outward to lip; lips not flared; nostrils terminal, protuberant, directed anterolaterally; internarial region slightly concave. Eyes large, directed anterolaterally, length greater than eye-nostril distance; eye length/eye-nostril distance $=1.5-1.6$. Upper eyelid width $43-48 \%$ of interorbital distance. Supratympanic fold absent or indistinct; tympanum covered by skin but visible through skin (at least in preserved specimens). Vomerine teeth absent; choanae small or moderate $(\approx 0.5 \mathrm{~mm})$, rounded; tongue round, entire, barely free posteriorly. Vocal slits extending from lateral base of tongue toward angle of jaw; distensible subgular vocal pouch.

Humeral spine absent; a very weak low, glandular ulnar fold, ${ }^{7}$ faintly pigmented white, extending from elbow along ventrolateral edge of arm to disc on finger IV. Relative length of appressed fingers III $>$ IV $>$ $\mathrm{I} \approx$ II. Webbing absent between inner fingers; webbing formula for outer fingers III 2-2 IV; a bulla in outer-finger webbing (see fig. 12 and Remarks). Finger discs broadly rounded to truncate. Thenar tubercle elliptical, low; palmar tubercle elliptical or somewhat rounded, low and barely distinct; several indistinct supernumerary palmar tubercles; subarticular tubercles small, low, entire. Nuptial excrescences not distinctively pigmented (not white), comprised of a line of gland cells (barely discernible in holotype) along edge of thenar tubercle on medial base of thumb and distally expanded as a larger and more evident patch of cells on dorsomedial surface of third joint. ${ }^{8}$ Prepollical spine absent (or not externally detectable by probing).

\footnotetext{
${ }^{7}$ The glandular nature of the ulnar fold is evident under magnification, but the structure is weak and not distinctively colored (white pigment present but sparse) in the preserved material and could easily be overlooked. A similar metatarsal fold is weaker still.

${ }^{8}$ These nuptial excrescences are medially much narrower and dorsally less extensive than in the type- 1 pad illustrated by Flores (1985: fig. 3A-C), but the distribution of gland cells follows the same pattern.
} 


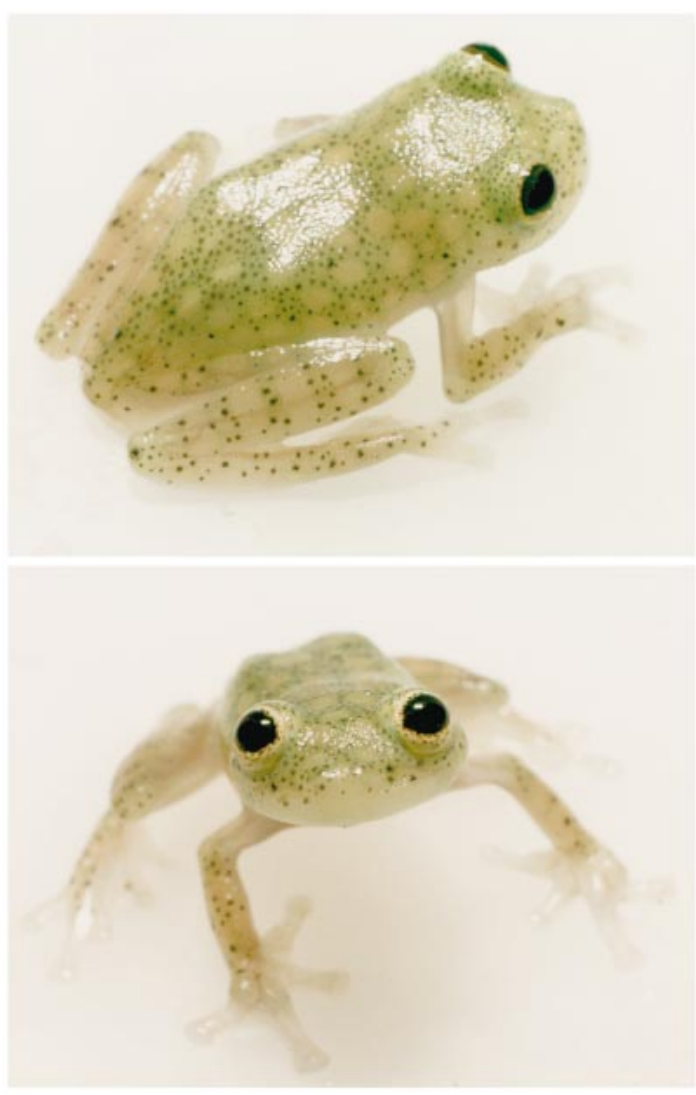

Fig. 9. Hyalinobatrachium eccentricum, new species. Two views of the paratopotype in life (AMNH 1591640). Note the weak but distinct crossbanding on the hindlimb. The bicolored iris has a golden yellow periphery and a dark brown median section in which the expanded pupil is barely visible as a broad ellipse. Absence of the usual bright pupillary ring causes the pupil to be virtually concealed because of lack of contrast with the adjacent brown part of the iris. The dark median section of the iris appears to be somewhat changeable in size and shape (see under Remarks).

Hind limbs slender; tibia length 49-50\% of SVL. Faintest trace of a slightly whitish, low metatarsal fold from heel to disc of fifth toe. Inner metatarsal tubercle elliptical, low; outer metatarsal tubercle smaller, low, barely distinguishable; subarticular tubercles low, round, entire. Feet moderately webbed; webbing formula I $2-2$ II $1^{1 / 2}-2$ III $1^{1 / 2}-2$ or $2^{1 / 2}$ [holotype] IV $2 \frac{1}{2}$ [holotype] or $2-1$ V. Toe discs broadly rounded, slightly smaller than those on fingers.

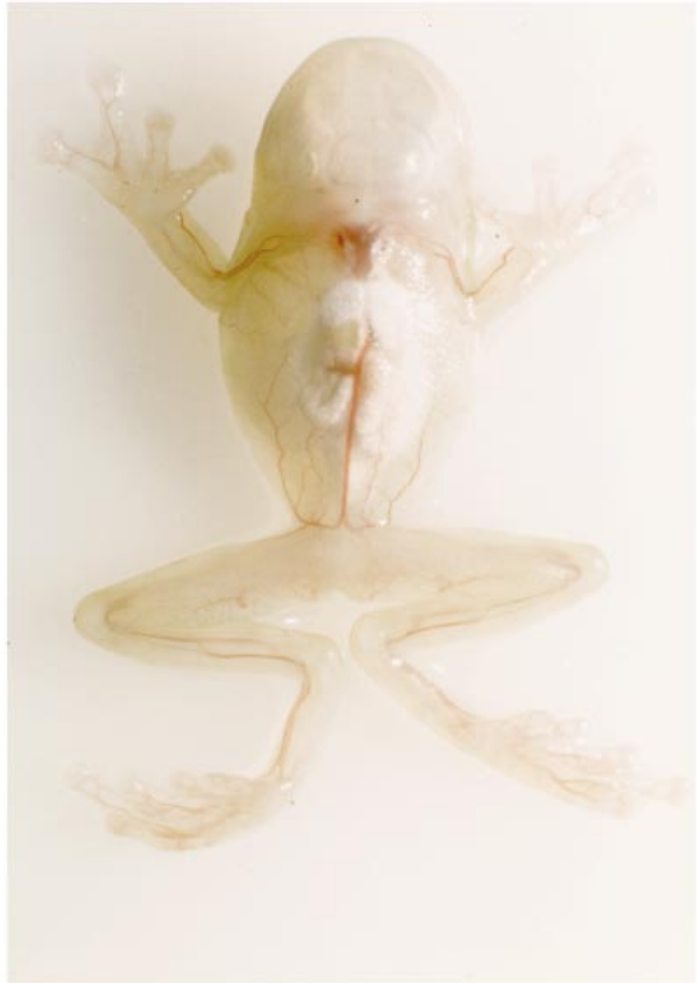

Fig. 10. Hyalinobatrachium eccentricum, new species. Ventral view of the holotype before preservation (EBRG 3049ð).

Skin relatively smooth overall except areolate on belly and ventral thigh surfaces. Vent directed posteriorly at upper level of thighs; cloacal opening concealed by short anal flap; anal ornamentation consisting of folds and tubercles with a slight whitish frosting overall.

COlOR AND PATtern: Changeable in life, pure green with dark green dots when seen at night (not photographically documented). Otherwise, head and dorsum with a pattern of clear, pale yellow or pale green spots (about size of tympanum) set in a light green reticulum that is dotted with dark green chromatophores; limbs grayish or yellowish, forelimbs with green dots irregularly arranged, hind legs with green-dotted, faint green crossbars on thigh and shank (fig. 9).

Parietal peritoneum clear. Lineae masculineae present. Pericardium variable: in holotype, heart mostly exposed, with pericardium appearing (from ventral view in life) to 

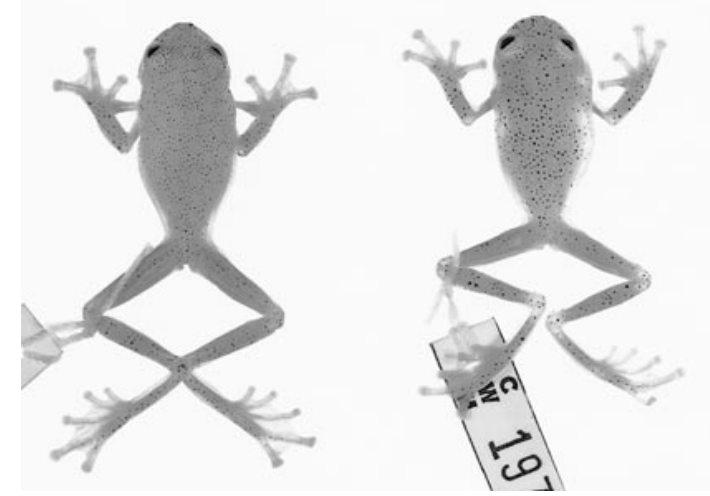

Fig. 11. Hyalinobatrachium eccentricum, new species. Note the loss of crossbars on the limbs after preservation (compare with fig. 9). Left to

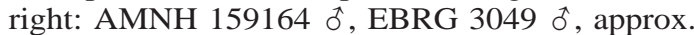
$\times 1.1$.

have white pigmentation principally above the heart; in paratopotype, pericardium mostly white except ventromedially, where heart was partly exposed. Liver, stomach, and intestines closely bound in silvery white peritoneum; gallbladder exposed (fig. 10). Bones white.

Eye coloration peculiar (figs. 9, 13B, C), with iris comprised of two strikingly different zones: (1) Peripheral zone of iris golden yellow, sparsely flecked with gray; and (2) medial, circumpupillary zone uniformly brown (little contrast with horizontal pupil, which lacks a bright pupillary ring) and markedly changeable in shape. The brown, medial section of the iris forms a broad ellipse around the expanded pupil in life (fig. 9, bottom). However, after euthanasia of the two frogs in chlorotone solution, the horizontal pupil contracted and the surrounding brown area became noticeably flattened below the pupil and domelike above it (fig. 13C). During formalin fixation, however, the brown circumpupillary zone regained an elliptical shape that has been retained in preservative (fig. 13B).

In preservative (fig. 11), dorsal surfaces are cream, eyelids paler; dorsal surfaces (including eyelids, lower arm, thigh, shank, tarsus, foot, and base of toes IV-V) are dotted with purplish black chromatophores of varying size. Crossbars on hind legs no longer evident. Ventral surfaces uniform cream, internal organs not discernible.

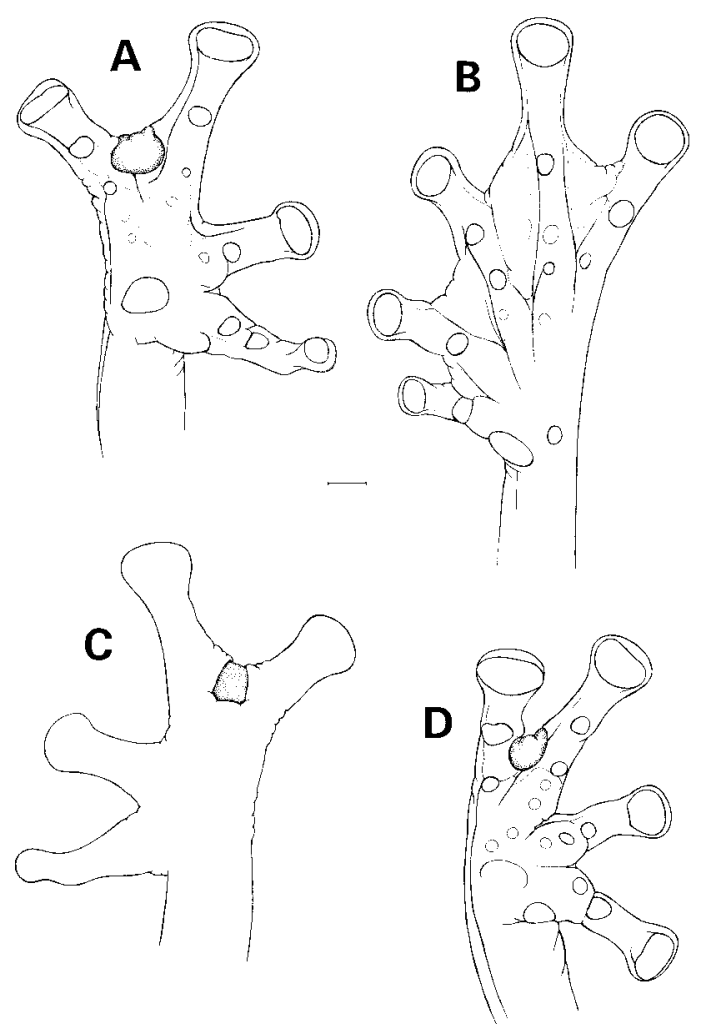

Fig. 12. Hyalinobatrachium eccentricum, new species. A, B: Right hand and left foot of male paratopotype (AMNH 159164). The raised or bubblelike ventral expansion of the web between fingers III and IV is an apparently novel structure, the bulla, that is shared with $H$. crurifasciatum (see fig. 15). C: Dorsal outline of the above hand, showing the distinct dorsal depression of the bulla. D: Right hand of the holotype (EBRG 3049). The bullae are not differentiated by pigmentation and are shaded for emphasis only. A possibility that the bullae might be induced by parasitism cannot be discounted and needs investigation (see Remarks in text). Scale line $=1 \mathrm{~mm}$.

\section{Natural History and Vocalization}

This species - the only centrolenid seen or heard during our six nights on Cerro Yutajé-was found perched near a little waterfall above a small stream in closed, mossy forest. It was a small group of fewer than 10 males calling in a concentrated area; the frogs were calling by night up to $3 \mathrm{~m}$ aboveground in dense vegetation. They were the devil to find even with three headlights triangulating on the calls. The only two frogs located were 

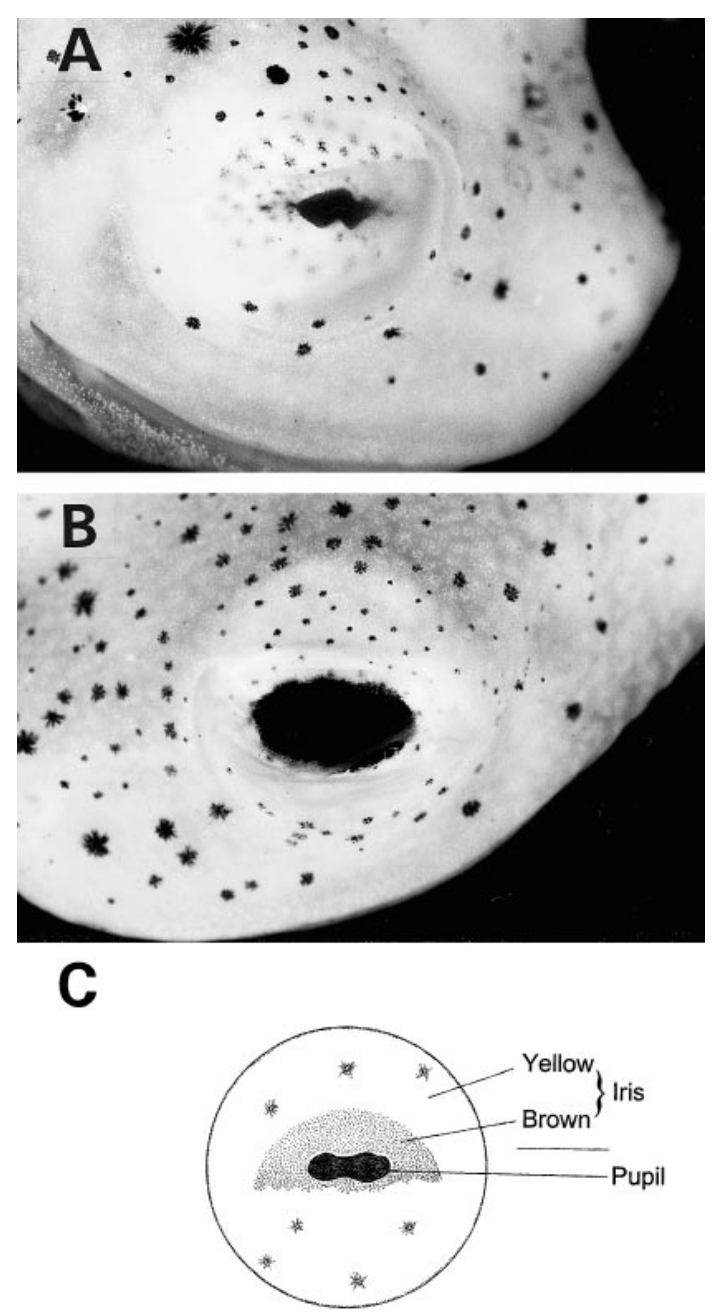

Fig. 13. Diagnostic iris patterns retained in preservative, roughly $\times 10-12$. A: Hyalinobatrachium crurifasciatum Myers and Donnelly, right eye of holotype (AMNH 131329 ఓ)—showing horizontal pupil through the transparent nictitating membrane. B: Hyalinobatrachium eccentricum, new species, left eye of holotype (EBRG 3049 ‘ै) - showing dark central section of iris (the horizontal pupil is not evident in this photograph owing to lack of contrast); the nictitating membrane is deflected downward. C: Enlarged rendition of field sketch of eye of Hyalinobatrachium eccentricum, after specimen had been relaxed in chloretone solution. In addition to the rough field drawing, the central part of the iris was noted as "domelike, with flattened lower side, and brown (little contrast with horizontal pupil)". The median dark zone regained an elliptical shape after preservation (as in part $\mathbf{B}$ above). calling upside down from the undersides of leaves.

The vocalization (fig. 14) is a single-note "peep" infrequently given. A recording was obtained of a solitary note, captured early in nearly $2 \mathrm{~min}$ of tape. This note, $0.22 \mathrm{sec}$ in duration, is irregularly but distinctly pulsed (see waveforms). There is initial frequency modulation, with the note abruptly rising from about $3480 \mathrm{~Hz}$ to a flat frequency of $4160 \mathrm{~Hz}$ (fig. 14, top).

\section{REMARKS}

The two type specimens were not dissected. Although the gallbladder is exposed, the liver is bound in white peritoneum (fig. 10) as is characteristic of Hyalinobatrachium (Ruiz-Carrenza and Lynch, 1991a: 23). Shape of the presumably bulbous liver, however, was not explicitly determined. Fieldnotes stated "2 lobes visible through white covering".

Hyalinobatrachium eccentricum is named for its peculiar eye, which was not noted until the two specimens were examined with a jeweler's loupe, after they had been killed in chloretone solution prior to preservation. The eccentricity of a sharply bicolored iris, with a dark, dome-shaped circumpupillary zone, seemed so bizzare that a field sketch was made (fig. 13C). There was no realization then that the median zone of the iris could change shape, but photographs of a living frog (fig. 9) suggest that the dark, median dome becomes an ellipse concurrent with pupillary expansion; a more shallow elliptical shape was regained during fixation (fig. 13B).

The fact that frog pupils contract to extraordinarily diverse shapes is well known (e.g., Boulenger, 1879; Duke-Elder, 1958: 339, figs. 403-404: 339; Walls, 1942: fig. 87 ) and is widely documented in countless published photographs of species in different genera and families. Nevertheless, we are unaware of any report of a nonsymmetrical change in the appearance of the central part of the iris itself. Iris constriction in the few anurans studied seems to be mainly an autonomous response to light that is mediated by the sphincter pupillae muscle (e.g., Rubin 


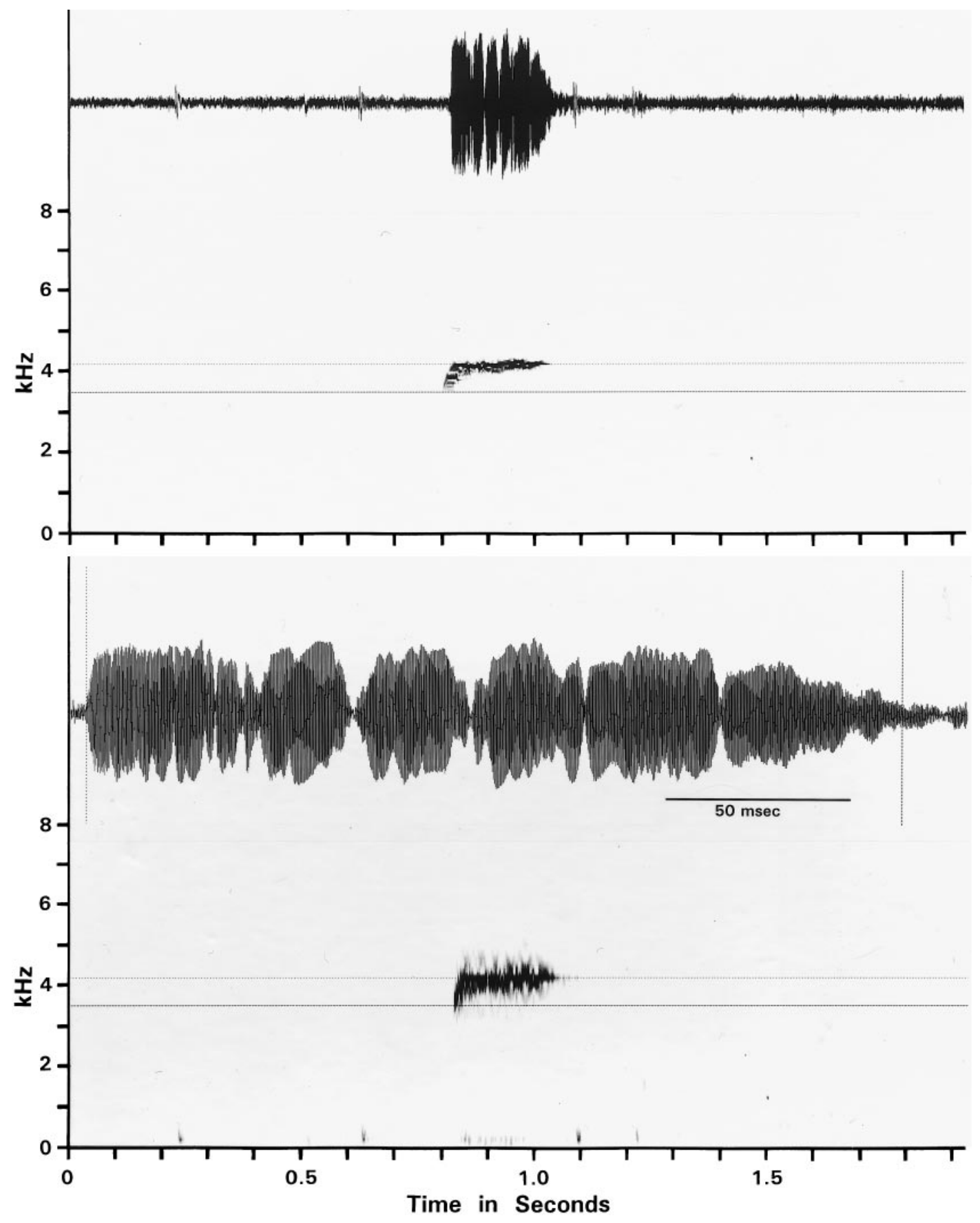

Fig. 14. The single-note advertisement call of Hyalinobatrachium eccentricum, new species, from a frog calling on underside of Philodendron leaf $1.3 \mathrm{~m}$ above small forest stream. Top: Sound spectrogram graphed with narrow-band $(59 \mathrm{~Hz})$ filter, with frequency cursors set at 3480 and $4160 \mathrm{~Hz}$, and matching waveform. Bottom: Wide-band $(300 \mathrm{~Hz})$ spectrogram of the same note and expanded waveform. The time between waveform cursors is $0.219 \mathrm{sec}$. Specimen (AMNH 159164) recorded February 26, 1995, at air temperature of $17.0^{\circ} \mathrm{C}$ (AMNH herpetology reel 264:1). 


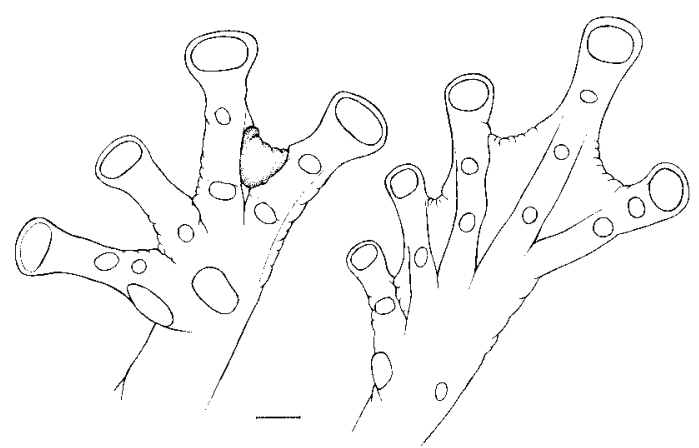

Fig. 15. Hyalinobatrachium crurifasciatum Myers and Donnelly. New drawings of the left hand and left foot of the male holotype emphasizing the bulla in the webbing between fingers III and IV (compare with fig. 12) and correcting the shape of the distal subarticular tubercle on toe V. Scale line $=1 \mathrm{~mm}$.

et al., 1986), but little comparative information is available.

Another notable aspect of the eye of $\mathrm{Hy}$ alinobatrachium eccentricum is the absence of a bright rim close around the pupil. Although absent in a few groups, a bright $p u$ pillary ring (continuous or broken) is so widespread among frogs (e.g., see fig. 16 of this paper) that it is usually ignored in descriptions of iris color. Walls (1942: 549) observed that

The common frogs, and many fishes and birds have the pupil outlined by a thin gold or silver line, the rest of the iris being so dark that the pupil would be beautifully concealed in it were it not for this metallic frame. To the adaptive colorationists, putting this ring around the pupil must seem about as mean a trick as hanging a bell on a cat.

A bright pupillary ring is usually present in centrolenids (e.g., see photographs in Lynch and Duellman, 1973; Ruiz-Carranza et al., 1996). There is little contrast between the pupil and the dark median zone of the iris of Hyalinobatrachium eccentricum, and the absence of the bright ring therefore causes the horizontal pupil to virtually disappear in photographs of both living and preserved specimens.

Another unusual characteristic of Hyalinobatrachium eccentricum is the structure here termed a bulla ${ }^{9}$ in the webbing between fingers III and IV. It is a shallow bubble on the ventral side of the web (fig. 12A, D), corresponding to a narrower, definite depression or pocket on the dorsal side (fig. 12C). We overlooked this structure in $H$. crurifasciatum, taking it only to be an artifact of preservation and not showing it in a diagrammatic drawing of the hand (Myers and Donnelly, 1997: fig. 8). We rectify that omission here with a more carefully drawn figure of the hand and foot of $H$. crurifasciatum (fig. 15). The bullae in figures 12 and 15 are emphasized by shading - there is no difference in pigmentation (or lack thereof, since the fingers and webs are essentially unpigmented; see figs. 9, 10), and the structure is easily discounted as an unimportant irregularity in the web or else it is overlooked entirely.

In the preceding discussion, we treat the bulla as a potentially informative taxonomic character, but there is another possibility that needs exploring. Our colleague Julián Faivovich has called our attention to parasitism in the Neotropical hylid genus Scinax, in which parasitic mites infect the web between toes IV and V. Examination of a few specimens of Bolivian Scinax nasicus (AMNH 144434, 144562-144563) revealed a variable-sized swelling, without a sharply defined perimeter, on the dorsal side of the outer toe webbing; these dorsal swellings appeared to be caused by acarid mites that cluster in the shallow corresponding concavity on the ventral side of the web (a kind of "mite pocket" usually associated with lizards); a sample of the mites from one specimen of Scinax nasicus (AMNH 144434) were identified as Microtrombicula sp. (Trombiculidae) by Dr. Ricardo Guerrero. Although the dorsal swellings in Scinax clearly are not the same as the well-defined bullae described above, one has to wonder whether a different parasite might account for (or be associated with) the dorsal pocketing/ventral swelling in the centrolenid finger web. The possibility cannot be discounted at this time, even though there is no direct evidence.

\footnotetext{
${ }^{9}$ Latin: bulla, -ae (bubble, knob, ornament), dim. bullula.
} 
Hyalinobatrachium eccentricum and $H$. crurifasciatum are structurally very similar. Unusual shared characters include the bullae (figs. 12, 15) and the narrow green crossbars on the legs (e.g., fig. 9, top) that disappear in preservative. The advertisement call of each species is a well-spaced, frequencymodulated, irregularly pulsed "peep", the single note starting at roughly $3.5 \mathrm{kHz}$ and rising to $\geq 4 \mathrm{kH}$, with a duration of $0.2 \mathrm{sec}$ or more. However, only a single note of $e c$ centricum was recorded (fig. 14), whereas Myers and Donnelly (1997: 14-15) described call variation in note duration and frequency modulation in what appeared to be a single calling individual of crurifasciatum; they suggested that such variability might be an antipredator mechanism. Except for their very different irises, we likely would have identified the specimens of $H$. eccentricum as being conspecific with $H$. crurifasciatum.

The bicolored iris of Hyalinobatrachium eccentricum appears to be shared with a species in Surinam, based on three transparencies of AMNH 87629 (CWM 11033), collected at Brown's Berg in 1972. ${ }^{10}$ These slides show a Hyalinobatrachium that is colored similarly to $H$. eccentricum (pale green with yellowish spots); the iris has a peripheral golden yellow zone (like eccentricum), but the large median black section appears to be circular (vs. elliptical). In addition to the circularity of the median black section, this frog differs from $H$. eccentricum in having a more truncate snout, in having the hind legs spotted like the body (vs. crossbarred), and in having the gallbladder concealed (liver, gallbladder, and digestive track closely bound in white peritoneum, heart and lungs exposed). Fieldnotes suggest that the median black part of the iris was simply thought to be a greatly expanded pupil; from the transparencies, however, it seems to be too large and too circular for that (with correct lighting, the pupil should be discernible under the microscope).

\footnotetext{
${ }^{10}$ Specimens were not compared directly, since the Surinam material (AMNH 87629, 87630) is on loan to the Nationaal Natuurhistorisch Museum for study by Dr. Marinus Hoogmoed.
}

\section{FAMILY DENDROBATIDAE}

Colostethus undulatus, new species

Figures 16-22

HolotyPE: EBRG 3021 (field no. CWM 19700), an adult female from forest stream on Cerro Yutajé, $1750 \mathrm{~m}\left(5^{\circ} 46^{\prime} \mathrm{N}, 66^{\circ} 08^{\prime} \mathrm{W}\right)$, Amazonas, Venezuela; obtained February 24-25, 1995, by the AMNH-TERRAMAR Expedition. The type locality is a short walk upstream from from the Expedition's 1700m camp; see locality 1 on map (fig. 1).

PARATOPOTYPES: AMNH 159118-159142 (159139-159140 skinned carcasses, 159141-159142 cleared \& stained), 159143 (7 tadpoles), EBRG 3022-3047 (3024 cleared \& stained), 3048 (8 tadpoles), from same locality as holotype, collected in the period February 24-28, 1995, by the AMNH-TERRAMAR Expedition.

ETYMOLOGY: The species name is a Latin adjective meaning undulating or wavy, in reference to the characteristic dorsal marking.

Definition AND Diagnosis: A mediumsized Colostethus (about 20-25 mm SVL) with black sides and a usually conspicuous wavy-edged dorsal marking; feet webless except for rudimentary basal web between toes III and IV. Lacking pale lateral or discrete dorsolateral lines, lacking cloacal tubercles, and lacking a median lingual process. Unusual external characters include a swollen supracarpal pad in males and an unusually small subarticular tubercle on base of fourth toe; an unusual osteological character is the concealment of all but the cultriform process of the parasphenoid. (See Remarks).

The undulating dorsal pattern also is unusual in Colostethus, although similar but less constant markings occur in the variation of a few species, including $C$. mandelorum (Schmidt), a moderately webbed species from the eastern coastal range of northeastern Venezuela. The absence of a pale inguinal line and its nearly webless feet immediately differentiates $C$. undulatus from that species, as well as from $C$. guanayensis on an adjacent tepui.

MEASUREMENTS OF Holotype (in $\mathrm{mm}$ ): The holotype is an adult female as determined by examination of its reproductive tract (and as indicated by size, absence of 

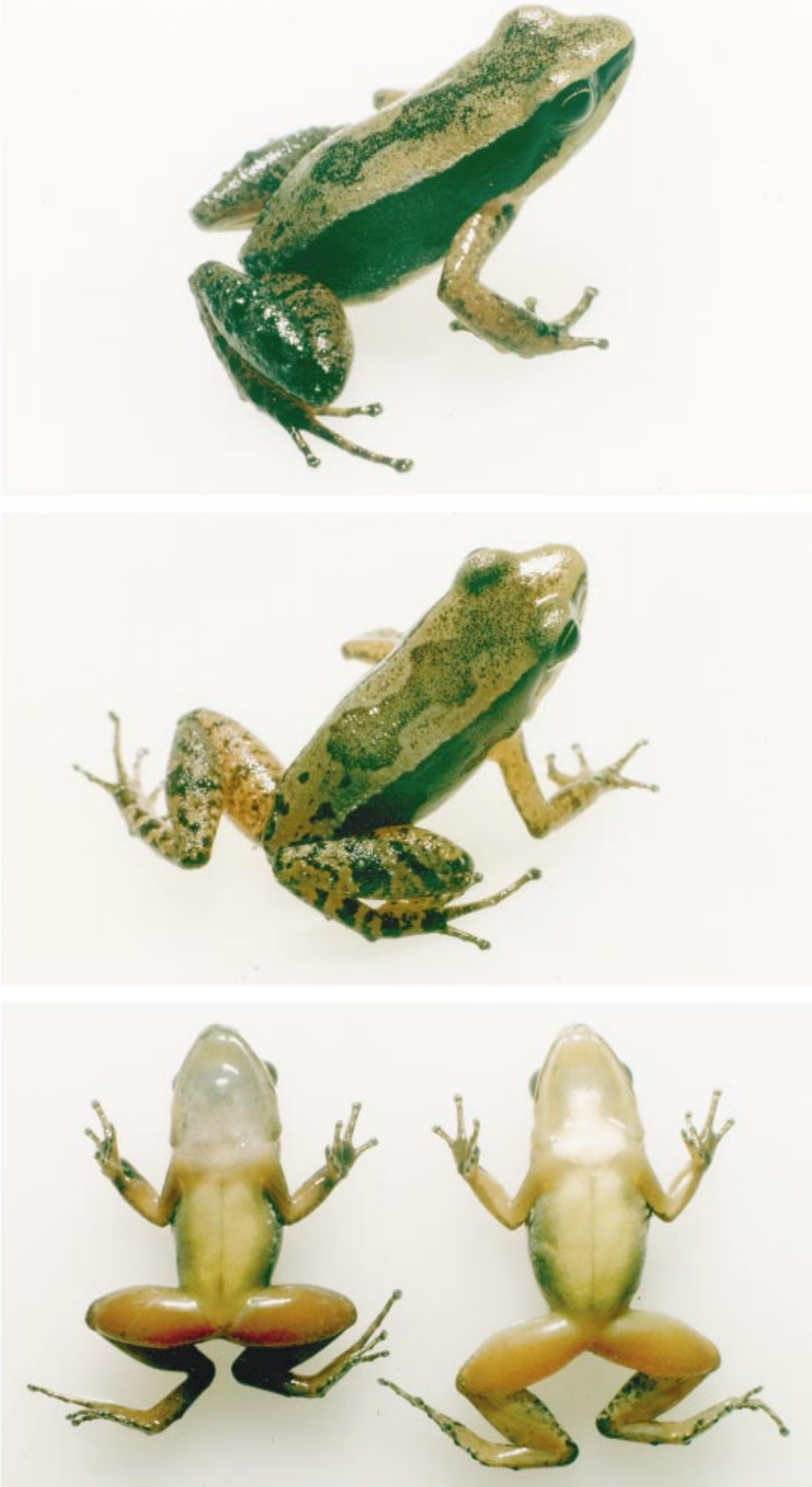

Fig. 16. Colostethus undulatus, new species, in life. Top: A male paratopotype (AMNH 159188). Middle: The female holotype (EBRG 3021). Bottom: Same specimens in ventral view, male on left, female holotype on right. 
TABLE 1

Size (in mm) and Proportions of Colostethus undulatus, New Species, from the Type Locality

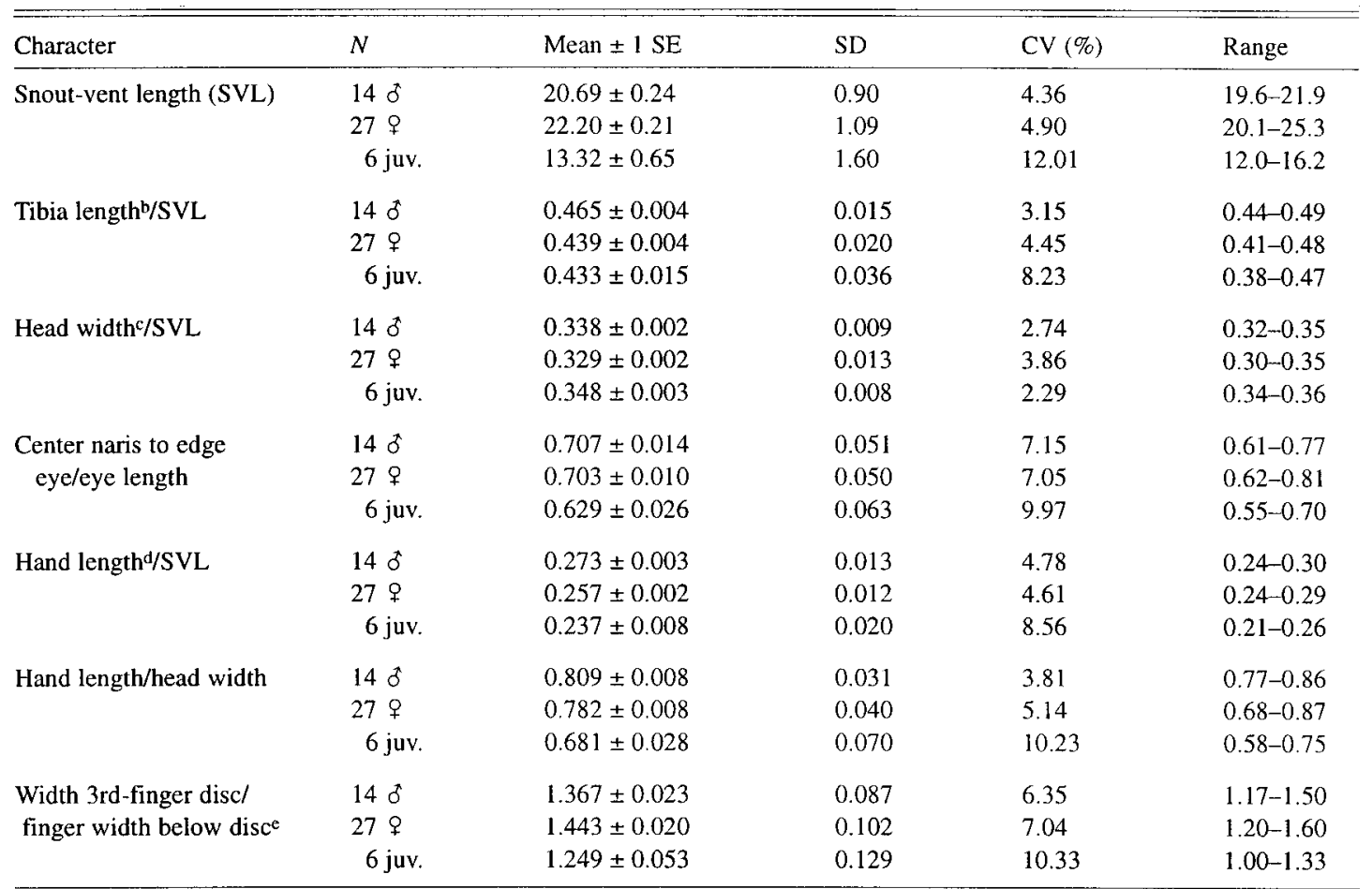

aFive additional adult female paratopotypes were skinned in the field and are excluded from this table.

bTibia length is the shank measured from the heel to the convex surface of the knee (with limb segments flexed at right angles), roughly approximating length of the tibiofibula.

${ }^{c}$ Greatest head width as measured between jaw articulations.

dHand length measured from proximal edge of large medial palmar tubercle to tip of longest (3rd) finger.

eDigit width measured near distal end of penultimate phalanx.

vocal slits, and pale throat). Length from snout to vent 22.2 ; tibia length between heel and outer surface of flexed knee 10.1; greatest width of body 8.3 ; head width between angles of jaws, and between outer edges upper eyelids, 6.8, 6.1, respectively; approximate width of interorbital area 2.7; head length from tip of snout to angle of jaw 6.0 (sagittal) or 7.1 (diagonal); snout length from tip to edge of eye (sagittal) 2.6; center of naris to anterior edge of eye 1.9; distance between centers of nares 2.9; eye length from anterior to posterior edge also 2.9; horizontal diameter of tympanum about 1.2 (concealed dorsally and posteriorly); corner of mouth to lower edge of tympanic ring 0.7 ; hand length from proximal edge of large medial palmar tubercle to tip of longest (third) finger 5.6; width of disc of third finger (and width of penultimate phalanx below disc) $0.6(0.4)$; width of 3rd finger at base 0.6 ; width of discs (and penultimate phalanges below discs) of third and fourth toes 0.9 (0.5) and $0.7(0.5)$, respectively.

\section{DESCRIPTION}

There are 52 specimens in the type series, including 32 adult females, 14 adult males, and six unsexed juveniles. Five of the adult females were skinned in the field for subsequent myological and osteological examination; measurements and proportions of the other 47 specimens are summarized in table 1. Maturity of males was judged by presence of open vocal slits and usually by gray vocal 
pouches (unpigmented in two small adults). All females were opened by lateral incision on the right side, and all were seen to have active ovaries and large or enlarging oviducts; dissection of skinned carcasses revealed about 3-4 large $(\approx 2 \mathrm{~mm}$ diameter $)$, pigmented ova in each ovary.

MORPHOLOGY: Dorsum weakly granular in life, becoming markedly tuberculate on hind legs (fig. 16). Dorsal skin becoming nearly smooth in preservative; ventral skin very finely granular to smooth in preservative. Vent opens at upper level of thighs, without a pronounced dorsal flap above vent; no anal sheath; posterior thighs coarsely granular or tuberculate proximally, but no pronounced or symmetrically arranged tubercles in cloacal region.

Head little wider than long; greatest head width (between angles of jaws) 30-36\% of SVL, averaging largest in juveniles (table 1). Snout sloping, rounded in profile, broadly rounded in dorsal and ventral view. Nares situated near tip of snout and directed slightly posterolaterally; nares visible from front, barely or not visible from above or below; posterior rim of naris raised slightly (but lacking any tuberclelike prominence); posterodorsal portion of raised rim often bordered behind by a crescent-shaped, finely incised groove. Canthus rostralis rounded; loreal region weakly concave, sloping slightly outward to lip. Interorbital region much wider than upper eyelid. Snout a little longer than eye length; center naris-edge eye/eye = $0.55-0.81$, shortest in juveniles (table 1). No discrete postrictal tubercles. Tympanum rather inconspicuous, concealed dorsally and posteriorly by a diffuse supratympanic bulge. ${ }^{11}$ Tympanum width revealed by dissection to be about one-half of eye length; tympanum positioned posteroventrally behind eye, with its lower edge close (0.5-0.8 $\mathrm{mm}$ in adults) to angle of jaws.

Hand (fig. 17) length in adults $24-30 \%$ of SVL, $68-87 \%$ of greatest head width. Relative lengths of appressed fingers III $>$ IV $\approx$ $\mathrm{I} \approx \mathrm{II}$, with slight individual variation; the first, second, and fourth fingers nearly equal when appressed, but with any one being

\footnotetext{
${ }^{11}$ This bulge, which reflects the underlying muscle, is too diffuse to be called a supratympanic fold.
}

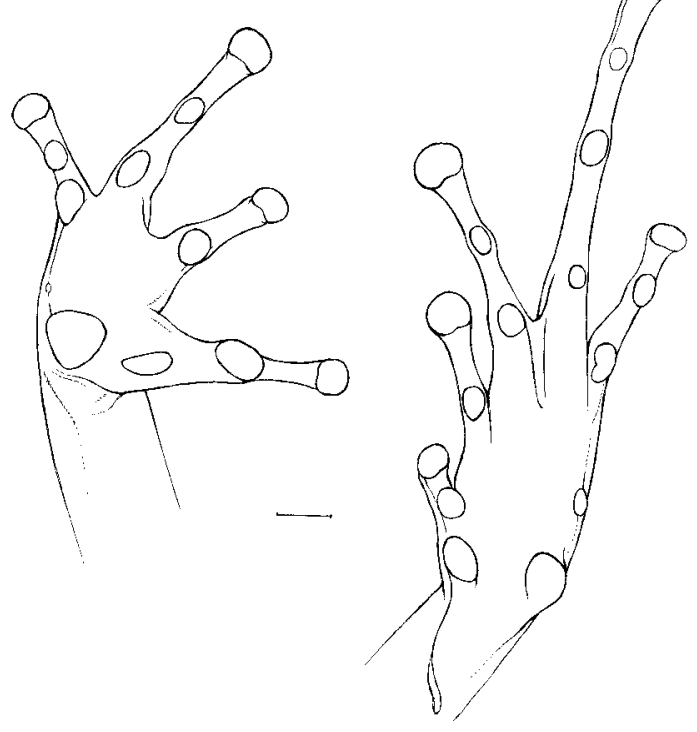

Fig. 17. Colostethus undulatus, new species. Right hand and left foot of female holotype (EBRG 3021). Scale line $=1 \mathrm{~mm}$.

slightly longer than others in one specimen or another (e.g., II > I > IV or IV > I > II). Discs of all fingers moderately expanded; third finger disc in adults 1.2-1.6 times wider than distal end of adjacent phalanx.

The third finger appears relatively slender in most females, slightly stouter in most males and perhaps a few females. In some males all the fingers appear stouter than in most females (fig. 18), although differences are subtle and not readily quantified. ${ }^{12}$

Base of palm with large median metacarpal tubercle, generally rounded; smaller elliptical inner metacarpal tubercle on base of first finger; one or two low, rounded subarticular tubercles (one each on fingers 1, 2, two each on fingers 3,4 ). No finger fringes (lateral keeling, especially on third finger, barely detectable under magnification). Faint trace of an outer metacarpal fold detectable

${ }^{12} \mathrm{~A}$ modified third finger characterizes some species of Colostethus s.1. and Epipedobates and may be plesiomorphic in these genera (summary discussion in Myers and Donnelly, 1997: 24-25). Although very well expressed in some species, sexually dimorphic finger widening is easily overlooked when barely developed (e.g., figs. 17, 18; also Myers et al., 1998, fig. 4), and the taxonomic distribution of this trait is therefore uncertain. 

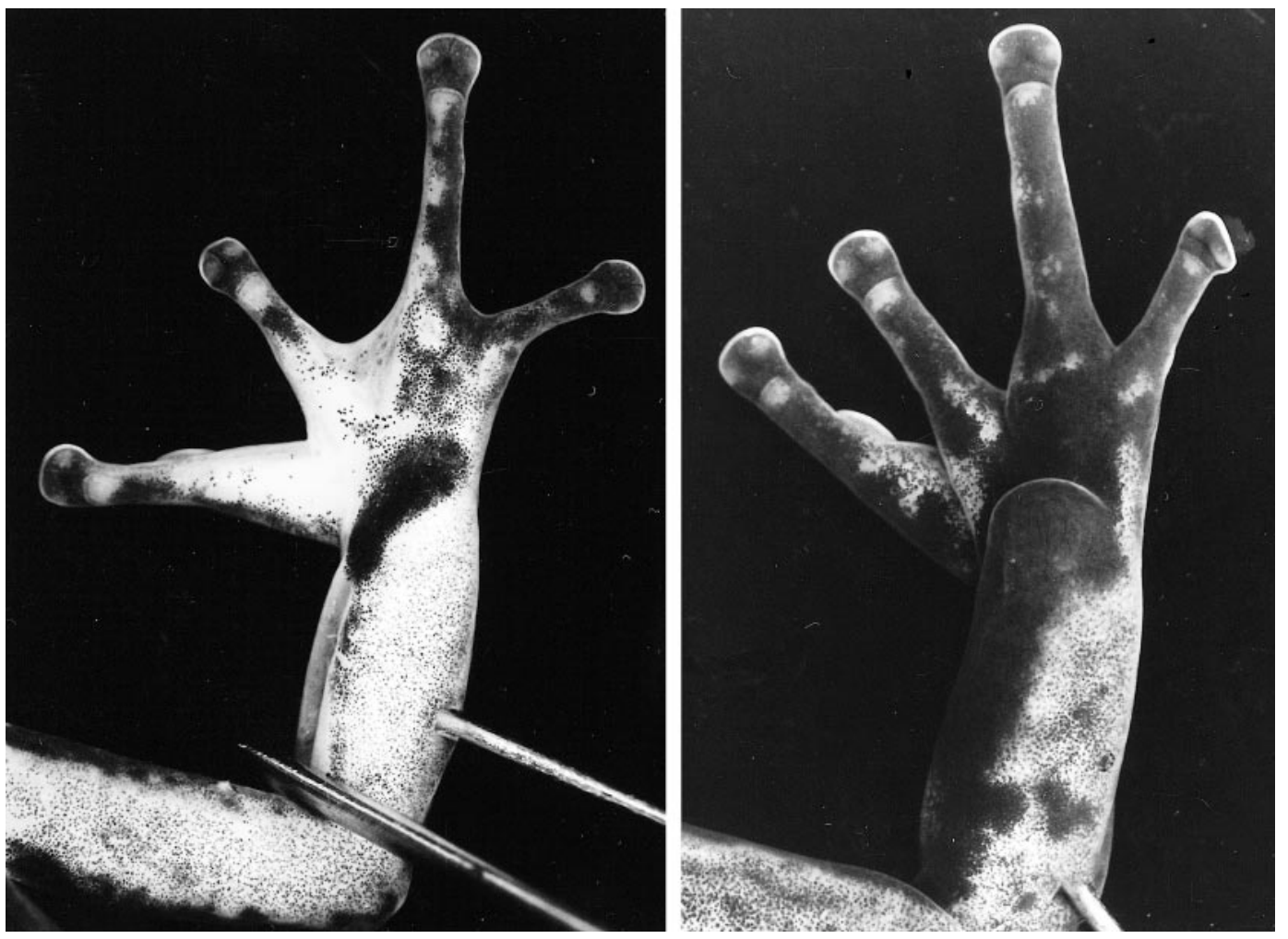

Fig. 18. Sexual dimorphism in hand and wrist of adult Colostethus undulatus, new species, as seen in dorsal view. Left: Right hand of female (EBRG 3042, $22 \mathrm{~mm}$ SVL), ×9.7. Right: Right hand of male (AMNH 159134, $21.5 \mathrm{~mm} \mathrm{SVL}$ ), showing stouter digits, swollen supracarpal pad atop wrist, and increased black pigmentation on forearm and hand, $\times 10.0$.

on some specimens but not others, sometimes bearing a minute tubercle on edge of palm between palmar tubercle and proximal subarticular tubercle of fourth finger. No ulnar tubercles or fold.

A fleshy, glandular supracarpal pad atop wrist (fig. 18), little developed in females but swollen in males, which also have a more pronounced overhang or crease around anterior margin of pad (supracarpal pad also associated with increased black pigmentation in males, see Color and Pattern; see also Remarks).

Hind legs of moderate length, with heel of adpressed limb usually reaching eye (not reaching eye in some females, a little beyond eye in some males); tibia $41-49 \%$ of adult SVL, relatively shorter in juveniles than adults on average (table 1). Relative lengths of appressed toes IV $>$ III $>\mathrm{V}>$ II $>$ I; first toe short, reaching or failing to reach base of subarticular tubercle of second toe. Discs weakly to moderately expanded on first and fifth toes, with discs on toes II-IV distinctly expanded and larger than finger discs. Toes nearly webless, rudimentary basal webbing sometimes arguably discernible between toes II and III, but distinct basal webbing only between III and IV (webbing formula III 3-4 or $4 \frac{1}{2}$ IV); this web variably pigmented, sometimes clear distally. Toes not fringed, lateral keeling weak or very faint even on facing sides of toes III and IV.

A small to moderate-sized elliptical inner metatarsal tubercle and a round outer metatarsal tubercle are subequal in size (either may be larger than the other); rarely a weak indication of a third tubercle between the inner and outer ones (e.g., AMHN 159128, EBRG 3044). One to three nonprotuberant subarticular tubercles (one each on toes I, II, two each on III and V, three on IV); subar- 
ticular tubercle near base of fourth toe very small, offset laterad. The faint keel along outer edge of the fifth toe is continuous with a weak outer metatarsal fold that terminates in a small but usually distinct tubercle distad from the outer metatarsal tubercle; no other supernumerary tubercles. Faint keel along free edge of first toe is continuous with a fold on distal third to distal half of tarsus; this usually weak tarsal fold becomes pronounced only at its proximal end, where it abruptly curves laterad and dorsad to terminate either as a prominent keel or a definite tubercle (fig. 17).

Teeth present on maxillary arch. Tongue longer than wide; free posteriorly, with rounded margin; no median lingual process. Vocal slits large, each extending from anterior edge of tongue nearly to angle of jaw.

COLOR AND PATTERN: In life (fig. 16), the dorsa were orangish brown with a usually prominent, wavy-edged, darker brown or grayish brown figure that remains conspicuous in preservative (fig. 19). Although no two markings are identical, there is constancy in general aspect and a tendency toward bilateral symmetry. The undulating figure extends posteriorly from between the eyes to past midbody, with one constriction before the arms and one after. This marking is obscure in only a few specimens (most notably AMNH 159122, see fig. 19); one specimen (EBRG 3034) has the anterior part of the marking broken off as an interocular triangle (fig. 19).

A black face mask, continuous around snout, widens behind the eye and becomes a broad lateral stripe, narrowly confluent above thighs with black seat patch. The contrast between black sides and brown dorsum is emphasized by the suggestion of a pale dorsolateral line (thin and ill-defined, not to be called a stripe), which was tan or pale grayish in life. There is some inconspicuous white flecking on the flank and into the groin (but no suggestion whatever of a pale oblique lateral stripe nor any clear development of a ventrolateral stripe). A pale bronze labial stripe is posteriorly continuous to the upper arm, often emphasized by black pigmentation along the mouth edge.

Arms pale orange in life, without discrete crossbands but with tendency for a black stripe along anterior (medial) side of upper arm. A diagonal black wrist marking of variable size, mostly small and confined to top of wrist in females, but in males larger and extending proximally and medially along lower arm, sometimes covering most of medial side of arm nearly to the black stripe on forearm. Upper sides of thighs and shanks brown-or shanks brown and thighs orange-with darker brown crossbands; posterior thigh surface either brown with a suffusion of orange or overall bright orange.

Throats pale to dark gray in most males (see comment on preserved specimens below), with an ill-defined paler chin spot having a greenish tinge. Throats yellow or grayish yellow in females, sometimes with an area of white (although a well-defined light gray blotch on chin and median throat was noted in a preserved specimen, EBRG 3038); venter yellow, brightened by underlying (silvery?) peritoneum. Undersides of arms orange, undersides of hind legs brighter orange. Undersides of hands and feet blackish brown or black, this color extending proximally along ventrolateral sides of lower arm and tarsus to elbow and heel.

Iris orangish bronze, with some dark suffusion or venation, and a clear bronze pupillary ring.

Juveniles look like the adults except that the smallest specimens (about $12 \mathrm{~mm}$ SVL) had the throat and venter pale gray in life (vs. yellow venters in adults) and the orange coloring on the undersides of limbs was paler and less bright.

In preservative (fig. 19), the dorsal ground color has faded to a duller brown or grayish brown. The axilla (not noted in life) is whitish, presumably colored like the venter in life. The undersides of the heads in males remain pale gray to blackish gray in preservative, usually with a vaguely paler chin spot; two small adult males have unpigmented throats. Ventral surfaces otherwise mostly yellowish white, with a tinge of pale orange lingering on undersides of thighs. Underside of shank whitish in preservative, with a variable dusting of melanophores.

\section{Myology AND OSTEOLOGY}

MyOlOGY: Basic information is provided by five adult female paratopotypes that were 

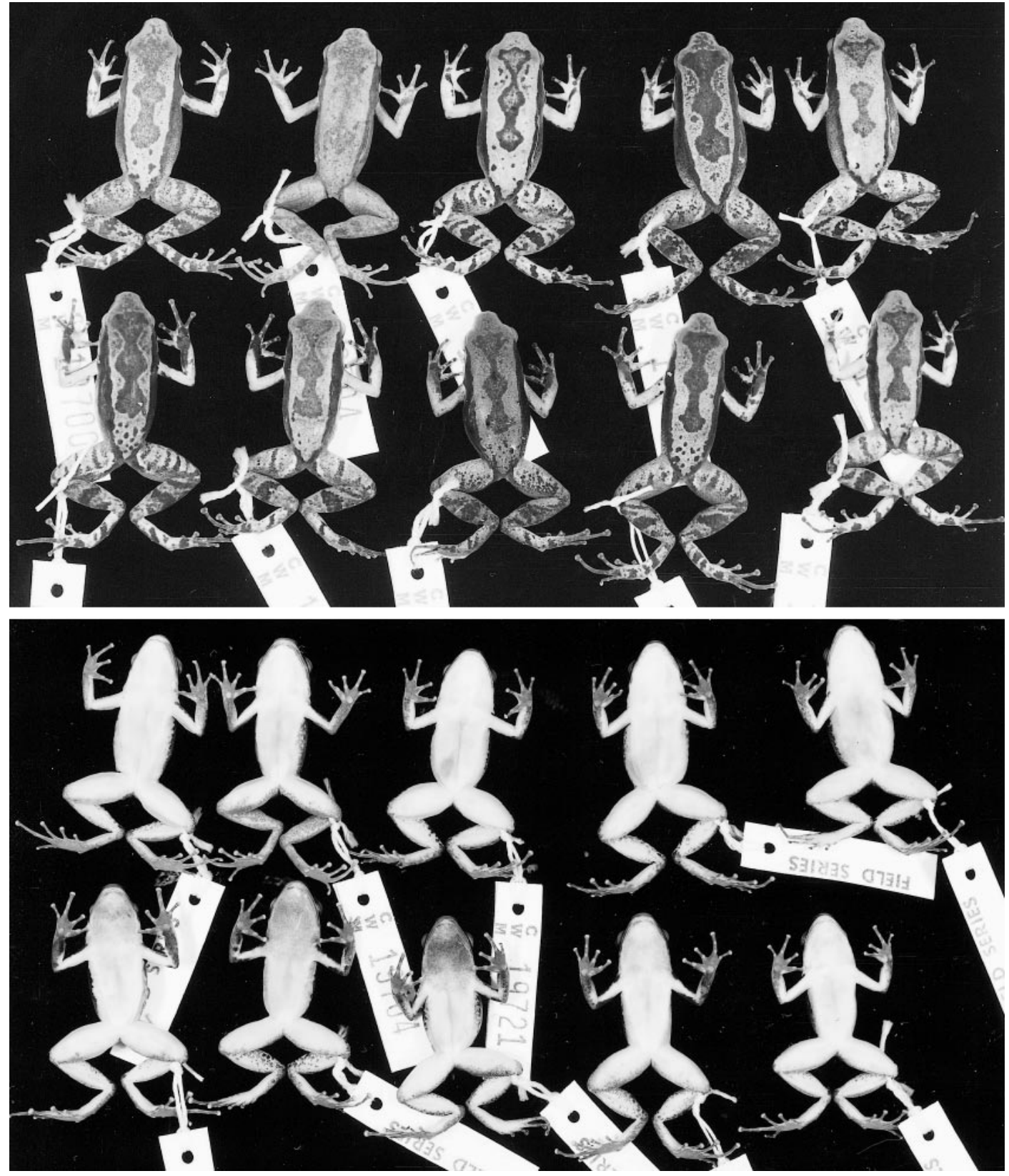

Fig. 19. Colostethus undulatus, new species, in dorsal and ventral view, $\times 1.1$. Top row, females: Left to right: EBRG 3021 (holotype), AMNH 159122, EBRG 3025, AMNH 159133, EBRG 3034. Bottom row, males: EBRG 3026, AMNH 159131, 159132, EBRG 3031, 3046. Virtually the full range of variation in dorsal color pattern is shown; the vestigial and broken patterns in two of these frogs (2nd and 5th from left in top row) are unique in the type series of 52 specimens. 
skinned in the field. Selected deep muscles were examined by dissection on three of these specimens prior to clearing and staining. The muscle fasciae bear only scattered melanophores and the flesh appears white (vs. gray or black in some dendrobatids).

The massive superficial slip of the $\mathrm{m}$. depressor mandibulae originates from the dorsal fascia and overlaps the posterodorsal edge of the tympanum; a much greater part of the dorsal and posterior part of the tympanum is concealed externally owing to the bulk of the muscle, which prevents close association with the skin. A concealed, deeper slip of the $\mathrm{m}$. depressor mandibulae has a combined origin from the otic ramus of the squamosal and the posterior margin of the tympanic ring.

There is no m. adductor mandibulae externus superficialis. The mandibular branch of the trigeminal nerve (visible without dissection on both left and right sides of all five carcasses) laterally crosses the deeper $\mathrm{m}$. adductor mandibulae posterior subexternus, which passes under the anterior part of the tympanic ring, apparently originating partly from the tympanic ring as well as from the zygomatic ramus of the squamosal.

On the thigh, the tendon of the deep $\mathrm{m}$. semitendinosus distally passes through the loose, ligamentous attachments of the posterodorsal edge of the $\mathrm{m}$. gracilis complex, to insert on the tibio-fibula adjacent (distad) to the insertion of the single gracilis tendon.

OsTEOLOGY: Three specimens skinned in the field were cleared and stained-one stained for bones only (AMNH 159141), and two double-stained for bones and cartilage (AMNH 159142, EBRG 3024). The specimens are variously damaged and the following brief description is a composite.

Skull approximately as wide as long. Frontoparietals well ossified, in medial contact except for anterior notch. Sphenethmoid large, in close contact with frontoparietals. Nasal bones of moderate size, widely separated from one another, and barely in contact with sphenethmoid at their posteromedian corners. Elongated maxillary process of nasal extending posteroventrally past, and slightly overlapping, facial lobe of maxilla.

"Palatine" (neopalatine) bones absent. Ventrolateral process of sphenethmoid prom- inent. Vomers toothless and widely separated. Septomaxillae small. Sphenethmoid fused midventrally, ventrolaterally in contact with very large optic foramen in one doublestained specimen, narrowly separated by a rim of cartilage in the other. Only anterior ramus (cultriform process) of parasphenoid visible, with rest of parasphenoid seemingly fused with otoccipital by overlying bone that is anteriorly delimited by a distinct transverse suturelike edge, in front of posterior edge of optic foramen. Extending forward from this is the cultriform process, a stout bone, with sides nearly parallel except for slight divergence rostrad; cultriform process overlain by bone anteriorly, at its abrupt terminus in posterior concavity of sphenethmoid.

Alary processes of premaxillae projected dorsally (nearly vertical), with a lateral inclination. Moderate-size maxillary and premaxillary teeth markedly recurved at tips, the posterior maxillary teeth small but retaining the recurvature; teeth possibly nonpedicellate, ${ }^{13}$ although a few breaks can be found near maxilla. Squamosal triradiate, but anterior zygomatic ramus very short; otic ramus somewhat longer than ventral ramus. Anterior ramus of pterygoid long and slender, posterior ramus short and robust, medial ramus very short. Retroarticular process of mandible long and prominent.

Hyoid plate (damaged) cartilaginous, wider than long; elongate posteromedial processes ossified except for distal cartilaginous tips.

Eight presacral vertebrae, procelous, with nonimbricate neural arches; no vertebral fusions. Transverse processes of vertebrae IIVIII subequal, anteriorly directed on II, tending to be posteriorly directed on IV-VI. Sacral processes not dilated distally. Sacralcoccygeal articulation bicondylar.

Pectoral girdle firmisternal, with coracoids in medial contact; epicoracoid cartilage medially reduced and ossified. Coracoids much wider than long, greatly expanded along their medial contact. Clavicles long and very slender (threadlike), laterally fused with scapu-

\footnotetext{
${ }^{13}$ Myers et al. (1991: 11) noted that "The loss or significant obfuscation of the usual amphibian pedicellate condition warrants attention as a possible additional synapomorphy for the Dendrobatidae."
} 
TABLE 2

Measurements (in mm) of Colostethus undulatus Tadpoles ${ }^{\mathrm{a}}$

\begin{tabular}{|c|c|c|c|c|c|c|c|}
\hline Stage & $N$ & $\begin{array}{l}\text { Total } \\
\text { length }\end{array}$ & $\begin{array}{l}\text { Head-body } \\
\text { length }\end{array}$ & $\begin{array}{l}\text { Body } \\
\text { width }\end{array}$ & $\begin{array}{l}\text { Body } \\
\text { depth }\end{array}$ & $\begin{array}{c}\text { Tail fin } \\
\text { depth }\end{array}$ & $\begin{array}{l}\text { Oral disc } \\
\text { width }\end{array}$ \\
\hline 25 & 13 & $\begin{array}{c}19.0-32.6 \\
26.92 \pm 3.82\end{array}$ & $\begin{array}{c}7.7-12.9 \\
10.79 \pm 1.41\end{array}$ & $\begin{array}{c}4.9-9.2 \\
7.22 \pm 1.21\end{array}$ & $\begin{array}{c}3.8-7.8 \\
5.63 \pm 1.13\end{array}$ & $\begin{array}{c}4.3-9.1 \\
6.43 \pm 1.36\end{array}$ & $\begin{array}{c}2.0-3.2 \\
2.73 \pm 0.30\end{array}$ \\
\hline 37 & 1 & 37.2 & 14.8 & 9.6 & 7.2 & 6.8 & 2.8 \\
\hline 39 & 1 & 41.5 & 14.9 & 10.7 & 10.2 & 9.3 & 3.7 \\
\hline
\end{tabular}

a Values include means \pm 1 SD when $N>1$.

lae, medially not quite in contact with one another. Omosternum an elongate, mostly bony structure, cartilaginous across its wide base, anteriorly narrowing, and distally cartilaginous with a clublike terminus. Small sternum posteriorly bifurcated, partly ossified.

Phalangeal formula of hands 2-2-3-3, of feet 2-2-3-4-3. Each terminal phalanx prominently T-shaped.

\section{TADPOLES}

Nurse frogs carrying dorsal tadpoles were not seen. One lot of 15 free-living tadpoles (AMNH 159143, MBUCV 3048) was netted in water 7-45 cm deep at the edge of the forest-stream habitat of the type series, at places where there was little current (fig. 23, bottom). The lot includes 13 larvae in Gosner stage 25 and one each in stages 37 and 39 (measurements in table 2).

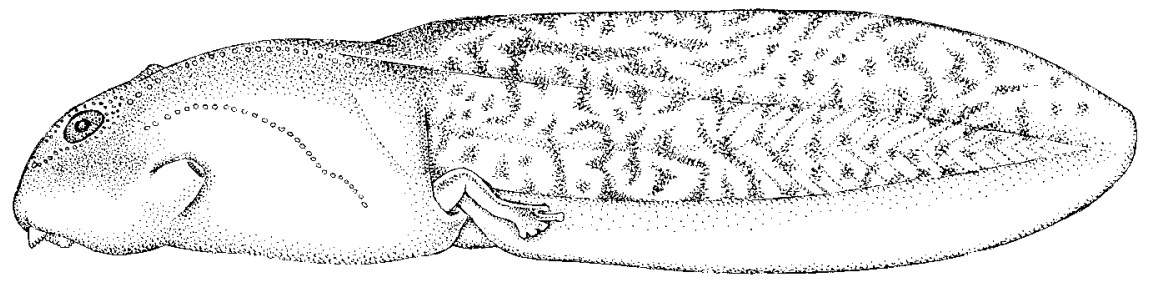

$10 \mathrm{~mm}$.

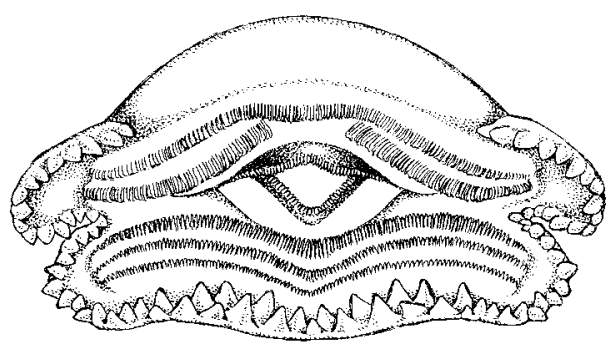

$1 \mathrm{~mm}$.

Fig. 20. Colostethus undulatus, new species. Stage-37 tadpole above, mouthparts of a stage-25 tadpole below (AMNH 159143). 


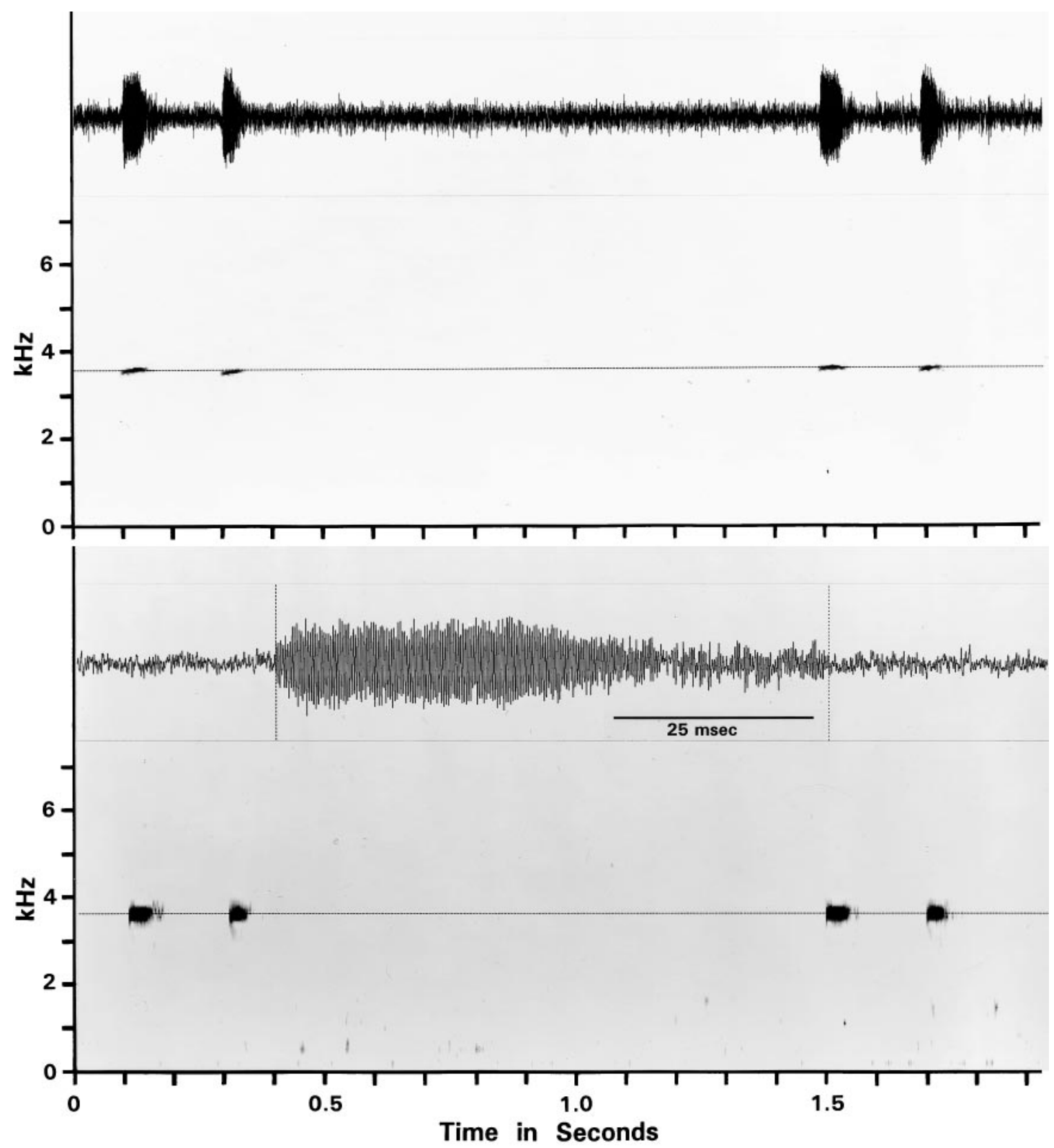

Fig. 21. Vocalization of Colostethus undulatus, new species; $1.9 \mathrm{sec}$ of a $90 \mathrm{sec}$ recording of variably spaced note couplets. Top: Sound spectrogram graphed with narrow-band $(59 \mathrm{~Hz})$ filter, with frequency cursor set at $3600 \mathrm{~Hz}$, and matching waveforms. Bottom: Wide-band (300 Hz) spectrogram of the same notes above and expanded waveform of the first note. The time between waveform cursors is $0.069 \mathrm{sec}$. Specimen (not caught) recorded 10:30 a.m., February 28, 1995, at air temperature of $19.8^{\circ} \mathrm{C}(\mathrm{AMNH}$ herpetology reel 264:3).

The following description is based on the single tadpole in stage 37 (fig. 20), followed by concluding comments on ontogenetic change.
Habitus AND Proportions: Viewed from above, the head and body form a somewhat elongated ellipse rounded at the ends, with midbody width $66 \%$ of head-body length. 


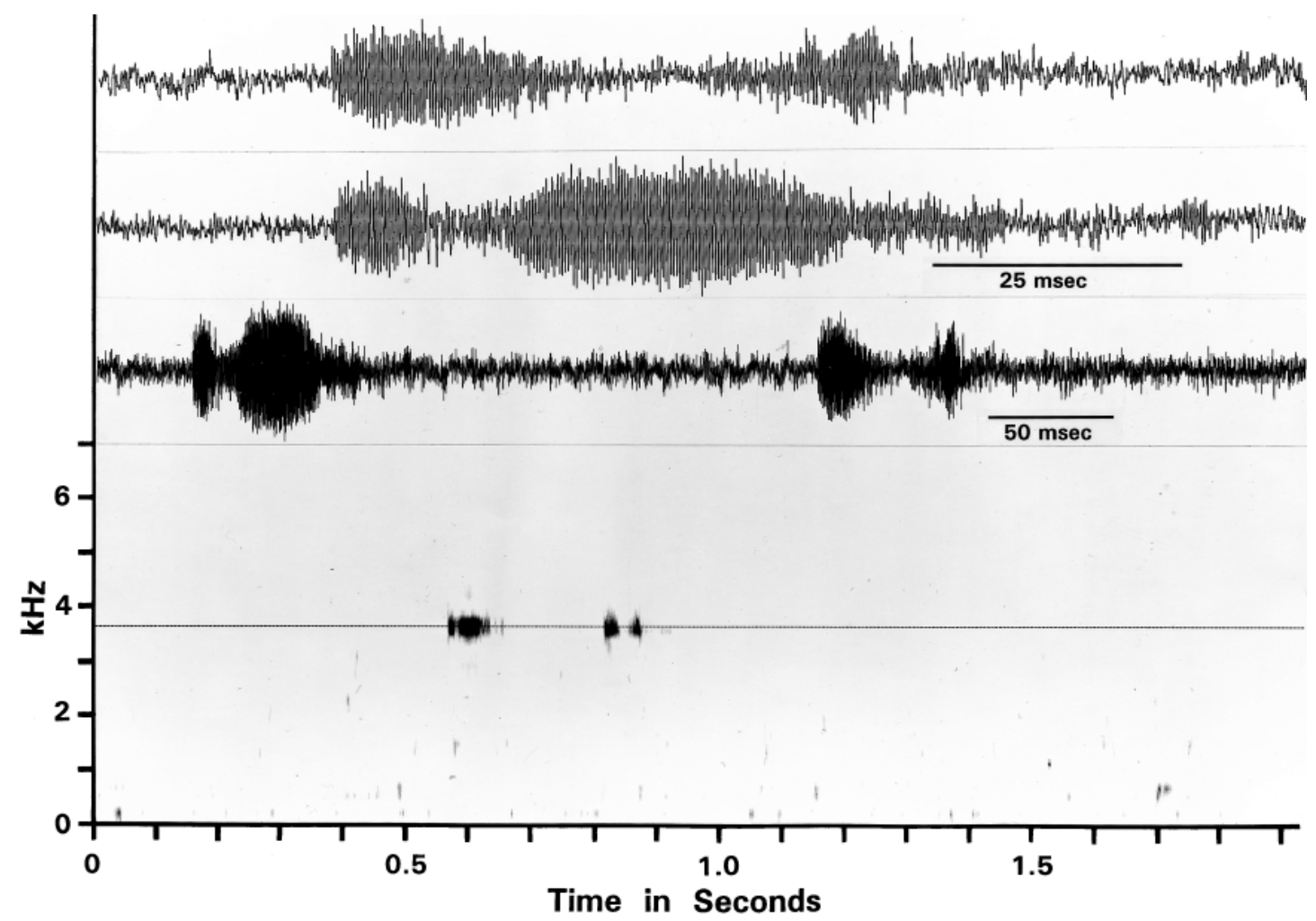

Fig. 22. Vocalization of Colostethus undulatus, new species; a pair of pulsed notes from the same train of couplets as the unpulsed notes in figure 21 . Wide-band $(300 \mathrm{~Hz})$ spectrogram, with frequency cursor at $3600 \mathrm{~Hz}$. Expanded waveforms show both pusatile notes together (bottom) and the first (middle) and second (top) notes separately.

Head-body depressed (midbody depth = $74 \%$ of midbody width), somewhat flattened dorsally and ventrally. Eyes and nostrils dorsal, directed dorsolaterally. Spiracle high on body (nearly midway between venter and dorsum), sinistral, a posterodorsally projecting tube about $1.2 \mathrm{~mm}$ long; its opening 8 $\mathrm{mm}$ behind snout, at $54 \%$ of head-body length. Vent tube dextral to caudal fin.

Lateral line system with a supraorbital and an infraorbital branch originating near upper labium and meeting behind eye. A dorsolateral branch rising behind eye and apparently terminating near end of body. A lateral branch curving above spiracle and dropping posteroventrally.

Caudal musculature not robust, tapering gradually, terminating anterior to tail tip. Tail $60 \%$ of total length and relatively high, with a greatest depth of $23 \%$ of total length. Tail high for most of its length, rounded at end; dorsal and caudal fins of approximately equal height.

Pigmentation in Preservative: Headbody dark brown above, turning pale below. Caudal musculature pale tan, fins transparent; conspicuous dark brown blotching over caudal musculature and on dorsal fin, only small clusters of melanophores on ventral fin (but ventral fin conspicuously blotched in some other specimens, or both fins nearly devoid of pigment). Grayish white iridophores conspicuous ventrally and on lower sides of body, sparsely distributed elsewhere on body and tail.

Mouth PARTs: Mouth ventral. Oral disc emarginate. Labial teeth in 2/3 rows: Anterior rows about equal in length, extending to near marginal papillae; second anterior row interrupted widely (in all specimens) above upper jaw sheath (row A1 continuous except for a seemingly anomalous narrow median 
break in the stage-37 larva but not in any other). First and second posterior rows subequal, slightly longer than third row. Upper jaw sheath a moderately wide arch, shallowly keratinized, with slender lateral processes; small blunt serrations. Lower jaw sheath Vshaped, shallowly keratinized; small blunt serrations like upper jaw. Marginal papillae bluntly pointed, single from lateral edges of anterior labium to posterior labium, where they become arranged in a weak double row.

ONTOGENETIC CHANGE: The smallest stage25 tadpole $(7.7 \mathrm{~mm}$ head-body length, 19.0 mm total length) seems to have a single row of marginal papillae. All the other larvae have a weakly doubled row of papillae on the posterior labium, although a single row is retained laterally and anteriorly.

\section{NATURAL History AND Vocalization}

Colostethus undulatus is a diurnal, terrestrial frog that was discovered in mossy gallery forest (fig. 23) at an elevation of about $1750 \mathrm{~m}$, not far upstream from our camp at $1700 \mathrm{~m}$ (fig. 6, lower). The forest at the type locality is continuous with the mossy forest at base camp, where Colostethus did not occur. The tendency of dendrobatids to occur in localized, apparently allopatric demes seems to be commonplace across all genera. Frequent if not constant diurnal calling by males makes it easy to locate demes such as this one. Excluding juveniles, there are 32 females and 14 males in the sample of 46 adults; this difference from a $1: 1$ sex ratio is statistically significant $\left(\chi^{2}=7.0435, P=\right.$ $0.00795)$, but whether it might reflect a difference in the actual sex ratio or in activity patterns is unknown.

The advertisement call of Colostethus undulatus is a pair (couplet) of notes repeated at varying intervals, usually at a rate of $<1$ couplet/sec. A single note seems to be only rarely interspersed in a train of couplets; one 62-sec segment of tape contains 27 couplets and one single note. Narrow-band analysis of calls from two frogs shows the notes to be narrowly tuned at a nearly flat frequency of either $3600 \mathrm{~Hz}$ (fig. 21, top) or $3720 \mathrm{~Hz}$. Waveforms in a series of calls from a single frog vary from nonmodulated (fig. 21) to dis- tinctly pulsatile, with two pulses per note (fig. 22).

Note duration is $0.04-0.11 \mathrm{sec}$, with sufficient separation to hear each note of a couplet. These are heard as peep-peep, coequal in loudness or either note louder than the other. The first note is longer than the second (occasionally equal), as shown by the following data for 27 couplets from a single frog, with a one-sided $t$-test for note $1>$ note 2 :

\begin{tabular}{lll}
\multicolumn{2}{c}{ 1st note } & 2nd note \\
\hline $\bar{x}$ & $0.073 \mathrm{sec}$ & $0.060 \mathrm{sec}$ \\
$\min$. & 0.05 & 0.04 \\
$\max$. & 0.11 & 0.08 \\
$\mathrm{SD}$ & 0.015 & 0.011 \\
$F=1.84768$, & $P=0.06197$ \\
$t=3.68791$, & $P=0.00029$ \\
\hline
\end{tabular}

The internote interval for 27 couplets from one frog is $0.08-0.30 \mathrm{sec}(\bar{x}=0.157, \mathrm{SD}=$ $0.055)$. Time between couplets varies from 0.76 to $4.19 \mathrm{sec}$ in a sequence of 19 couplets $(\bar{x}=1.699, \mathrm{SD}=0.754)$ from the same frog, but the recording of another frog includes several couplets that are more closely spaced $(0.44-0.49 \mathrm{sec})$. The intercouplet interval therefore is too variable to characterize the call as a uniform "train" of couplets.

\section{REMARKS}

The affinities of Colostethus undulatus are not known. It probably differs from most other named and unnamed tepui species in lacking a median lingual process (Grant et al., 1997: 5; Myers and Donnelly, 1997: 24). ${ }^{14}$ Somewhat similar dorsal markings appear as pattern variants in the repertoire of a few other species, including such divergent species as C. lacrimosus Myers (1991: fig. 6) and C. mandelorum (Schmidt, 1932; Rivero,

\footnotetext{
${ }^{14}$ We predict that most if not all of the web-footed highland species reviewed by La Marca ("1966" [1998] will be found to have a median lingual process. Among those species, for example, the lingual process is present in C. parkerae Meinhardt and Parmelee, Colostethus shrevei Rivero, and Colostethus tepuyensis La Marca. Photographs of the median processes of $C$. shrevei and C. tepuyensis (as Colostethus sp.) are given in Grant et al. (1997: fig. 3A, B), and the median process in $C$. shrevei is further illustrated in Myers and Donnelly (1997: fig. 17A, B), along with that of of another Venezuelan species (C. tamacuarensis, fig. 17C, D).
} 


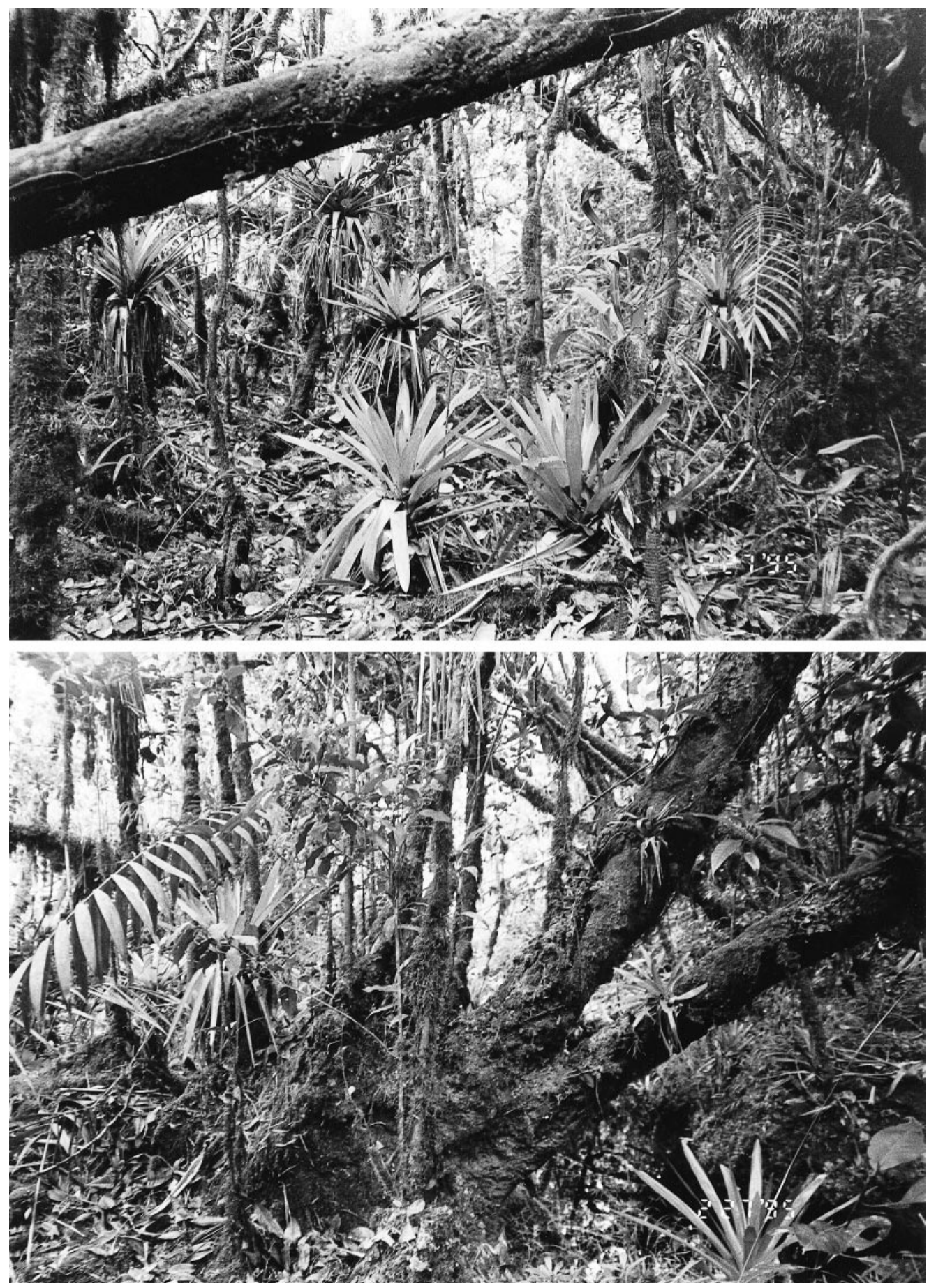

Fig. 23. Interior views of mossy forest on east side of the upper Río Corocoro, elevation about 1750 $\mathrm{m}$ (see fig. 6, bottom). Reflections from the surface of a small, sluggish stream can be seen in the lower photograph (right of center). This forest is the type locality of the frog Colostethus undulatus. (February 27, 1995) 
“1982” [1984]: fig. 1; La Marca, 1993: fig. 2), but they are not constant enough to be diagnostic. Complex dorsal markings, when they occur, generally are quite variable in Colostethus and rarely provide reliably diagnostic features. The remarkably consistent, sinuous dorsal figure of $C$. undulatus is therefore highly unusual in this regard.

Another unusual characteristic among dendrobatids is the concealment in C. undulatus of the parasphenoid. An overlay of bone apparently fuses the parasphenoid with the braincase, leaving the anteriorly projecting cultriform process as the only visible part of the parasphenoid.

Still another character of possible note is the subarticular tubercle on the base of the fourth toe-it seems unusually small in this species. Tubercle reduction on digits having two or more subarticular tubercles usually seems to involve the distal tubercle (as on the 4th finger of this species) rather than a basal one. This tubercle is offset laterad from the midline of the digit, a peculiarity that also pertains to some other species of the genus (e.g., see Myers and Donnelly, 1997: fig. 12), but these are casual observations and we cannot summarize its taxonomic distribution.

A character worthy of special attention is the fleshy, glandular swelling atop the wrist - the supracarpal pad (fig. 18), which seems either to be a novel structure in the Dendrobatidae or else one that has been overlooked in other species. Superficially, this swelling does not appear $($ at $\times 50)$ to be much different from adjacent skin (except in being blacker), but a difference is obvious when the pad is bisected from the wrist to the forearm (e.g., on left wrist of EBRG 3041). In longitudinal section, the pad is seen to be several times thicker than the adjacent skin and to be comprised of large glands in the dermis. The glands, which are easily seen even at low $(\times 6)$ magnification, are surrounded by melanophores, thickly so above and to the sides of the glands and thinly so below them. Below this is a conspicuous, bright layer of presumed iridophores. Finally, there is another heavy deposition of melanophores in the loose fascia on the innermost side of the thickened skin, which is loose above the wrist.

The supracarpal pad is superficially best developed in males; it is weak or vestigial in females. The function of the supracarpal pad is not obvious, although it conceivably might play a role in the unusual dendrobatid trait of cephalic amplexus. ${ }^{15}$ Only two types of integumentary glands-mucous and granular-are known to occur in most amphibians, including the Dendrobatidae (Neuwirth et al., 1979). The glands comprising the pad will therefore deserve special study to determine if they are modified granular glands or something else.

\section{FAMILY LEPTODACTYLIDAE}

\section{Eleutherodactylus cantitans Myers and Donnelly \\ Figures 24, 25}

Eleutherodactylus cantitans Myers and Donnelly, 1996: 11-14, figs. 7, 8. Holotype EBRG 3005 (field no. CWM 19684), an adult male from summit of Cerro Yaví, $2150 \mathrm{~m}$, Amazonas, Venezuela; collected February 23, 1995, AMNH-TERRAMAR Expedition.

MATERIAL: AMNH 159144-159159, 159160 (4 froglets), EBRG 3055-3071, 3072 (4 froglets), from Cerro Yutajé, 1700-1750 m, Amazonas, Venezuela; collected February 26-28, 1995, AMNH-TERRAMAR Expedition.

This series agrees well with our original description of the species, which was based on specimens from Cerro Yaví (Myers and Donnelly, 1996). However, as indicated below, the much larger sample from Cerro $\mathrm{Yu}-$ tajé gives better perspective on variation in size and proportions, and in color pattern, as well as in a few aspects of morphology. We also call attention to the "axillary tubercle", a diagnostically useful character of possible phylogenetic value.

\section{Supplemental Data From the Yutajé SAMPLE}

Females are larger than males ( $\bar{x}$ female $\mathrm{SVL} / \bar{x}$ male $\mathrm{SVL}=1.47)$. Adults are $22-45$

\footnotetext{
15 The dorsal sides of the fingers are pressed up against the female's head in dendrobatid cephalic amplexus, which would bring the supracarpal pads close to (or touching) the side of her chin. Cephalic amplexus, first demonstrated in Dendrobates (now Epipedobates) tricolor by Myers et al. (1978: fig. 6), is postulated as a dendrobatid synapomorphy that has been lost in Dendrobates + Phyllobates.
} 
$\mathrm{mm}$ SVL (20 males 22.5-30.6 $\mathrm{mm}, \bar{x}=$ $28.29 \pm 0.45 \mathrm{~mm}$; 6 females $36.9-45.2 \mathrm{~mm}$, $\bar{x}=41.47 \pm 1.15 \mathrm{~mm}$ ). All males have vocal slits and at least traces of a nuptial pad on each thumb, and all adult females have large or enlarging ova and oviducts. Seven smaller juvenile or subadult females (23.1-31.6 mm SVL, $\bar{x}=26.63 \mathrm{~mm}$ ) have small ovarian ova and nonconvoluted oviducts. Eight unsexed froglets are $12.8-17.1 \mathrm{~mm} \mathrm{SVL}(\bar{x}=14.99$ $\mathrm{mm})$.

Head wider than body, wider than long, or slightly longer than wide; head width 39$43 \%$ of SVL in adults, with no evident sexual dimorphism $(\bar{x}=43 \%$ in each sex $)$, but relative head width slightly smaller in the juvenile samples $(39-40 \%, \bar{x}=39.3 \%$ SVL in 8 unsexed juveniles $<18 \mathrm{~mm} ; 40-41 \%, \bar{x}=$ $40.3 \%$ SVL in 7 juvenile females). Eye-nostril distance $71-110 \%$ of eye length (20 males $76-90 \%, \bar{x}=83.4 \pm 0.011 \%$; 6 females $88-110 \%, \bar{x}=96.0 \pm 0.038 \%$; juvenile females 83-97\%; small juveniles $<18$ $\mathrm{mm}$ SVL 71-85\%). Supratympanic fold present, weakly developed, or absent. Posterior edge of tongue notched or entire.

Middorsal raphe present or absent. A large axillary tubercle (whitish in preservative), coded as absent only in four juveniles, is present in both males and females. The axillary tubercle varies from indistinct to very distinct (fig. 24), sometimes being as large as the tympanum (tympanum/tubercle width $\approx$ $1.0-2.8) .{ }^{16}$

Tibia 48-60\% of SVL (20 males 51-60\%, $\bar{x}=56.0 \pm 0.006 \% ; 6$ females $48-56 \%, \bar{x}=$ $53.6 \pm 0.012 \%$; juvenile females $56-59 \%$, small unsexed juveniles $<18 \mathrm{~mm}$ SVL $51-$ $57 \%)$.

Color Pattern: Fieldnotes and color transparencies show that the dorsal ground color of living Eleutherodactylus cantitans was various shades of brown, sometimes with a greenish suffusion (fig. 25). Although the dorsal pattern is polymorphic, most individuals have indication of a dark interorbital bar and a vaguely W- or X-shaped scapular marking (fig. 25, top right), followed

\footnotetext{
16 The axillary tubercle was not noticed in our original description of Eleutherodactylus cantitans. It is identifiable in all three of the AMNH paratopotypes from Cerro Yaví, but is distinct only in AMNH 143359 ㅇ․
}

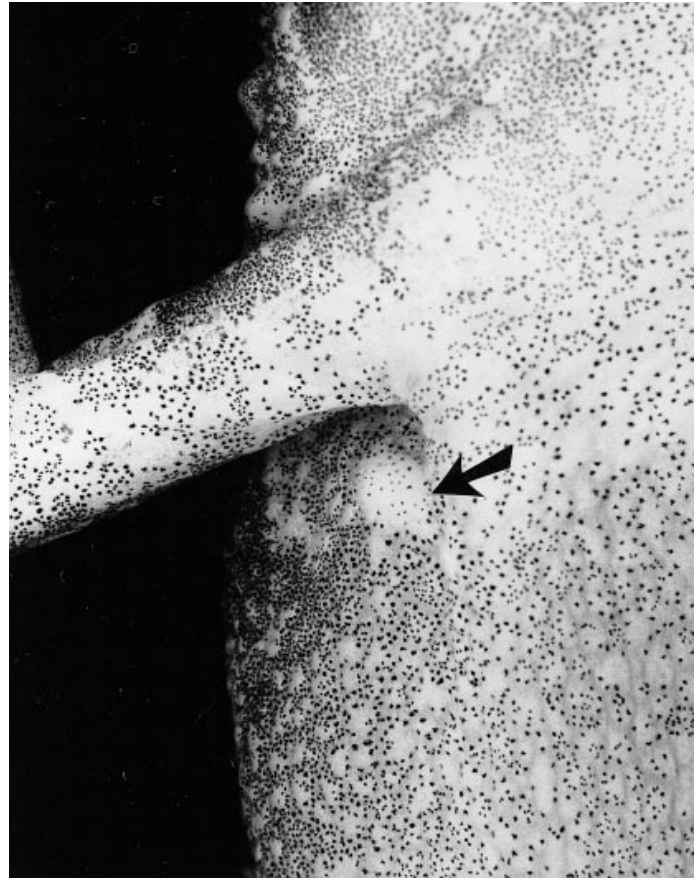

Fig. 24. A well-developed axillary tubercle in Eleutherodactylus cantitans Myers and Donnelly, from Cerro Yutajé (EBRG 3071 $q$ ). Right side, approximately $\times 6.8$.

posteriorly by other such dark markings as a few chrevrons or blotches and lumbar bar. Some are nearly uniformly dark, with only faint traces of darker markings, including two specimens with a distinct pale (whitish in preservative) vertebral line. Several specimens have scattered white or yellowish dots. One individual has a pale middorsum with slightly darker, wavy median and paravertebral stripes (fig. 25, bottom right).

Although not evident in figure 25, most individuals in life had a few yellowish oblique lines on the flanks, and yellowish to pale brown interspaces between the dark thigh bands. The rear surface of the thigh was gray with indefinite pale speckling and often with a rose suffusion. The ventral surfaces were gray in adults, usually with a weak suffusion of rose under the hind limbs and in the groin and sometimes on the belly; juveniles $<18 \mathrm{~mm}$ SVL had the ventral surfaces grayish black with areas of bronze. Except for a reddish brown horizontal stripe, the iris was pale gray overall, or gray below 

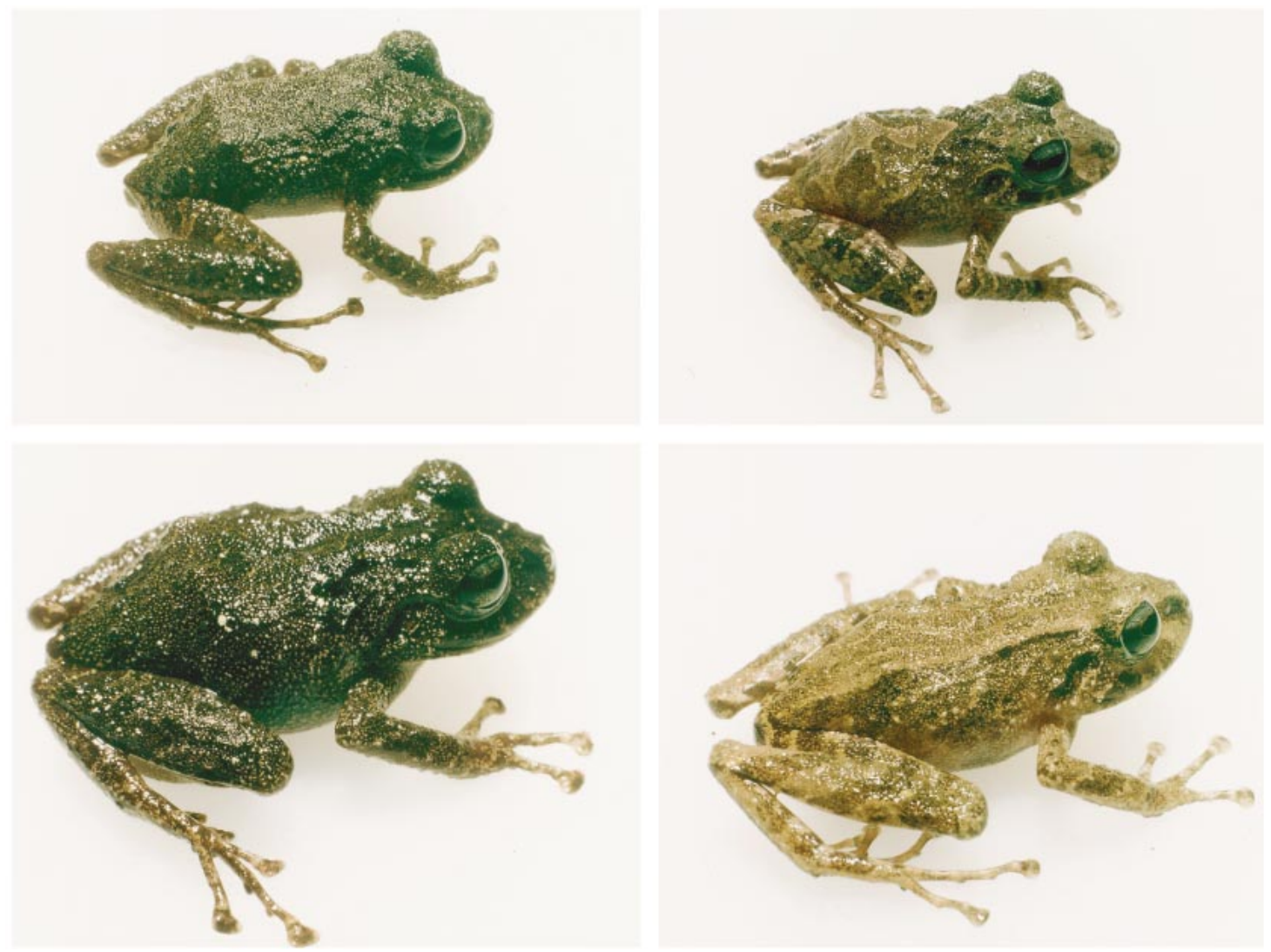

Fig. 25. Eleutherodactylus cantitans Myers and Donnelly, from Cerro Yutajé, 1700-m camp. Top row: Adult males, left to right, EBRG 3055 (31 mm SVL), EBRG 3056 (30 mm SVL). Bottom row: Adult females, left to right, AMNH 159144 (45 mm SVL), AMNH 159145 (37 mm SVL). (Not to same scale.)

the stripe and pale bluish gray or greenish gray above it.

In preservative, the dorsal ground color is light to dark brown. Ventral surfaces are light to medium brownish gray, sometimes vaguely mottled. The seat patch varies from light to dark. A few females and several males have traces of a pale median line on the throat. Lip bars radiating from the eye to the lip vary from distinct to vague as in life. For a few years after preservation, the rose wash could seen in the groin, on the flanks and ventral surfaces of the hind limbs, and in the axilla.

NAtURAL History: All specimens were captured at night, mainly in wet, mossy forest. Males were calling frequently, both day and night. (The name cantitans means "singing often", in allusion to the day-and-night calling behavior.) Eleutherodactylus cantitans was much more common at 1700-1750 $\mathrm{m}$ on Cerro Yutajé than in the higher, cooler forest at $2150 \mathrm{~m}$ on Cerro Yaví, whereas the situation was reversed in the case of $E$. $y a$ viensis, which was sympatric with cantitans in both places.

REMARKs: At the type locality, all specimens of Eleutherodactylus cantitans were noticed to develop a temporary blue-green metallic sheen during formalin fixation. Although transient, this color was useful in the initial sorting of the several sympatric species of Eleutherodactylus on Cerro Yaví. We neglected to look for this unusual coloring when fixing the series of specimens on Cerro Yutajé.

Fieldnotes describe Eleutherodactylus cantitans as having the rear of the thigh 
black at the type locality, but gray on Cerro Yutajé. Otherwise, the series from Cerro Yutajé agrees well with color and pattern variation shown by the type specimens from Cerro Yaví. Each sample includes a specimen of a morph having three irregularly wavy dark lines on a lighter middorsum (fig. 25, bottom right; Myers and Donnelly, 1996: fig. 7, upper). The unusual axillary tubercle also occurs in both populations. Although we failed to get comparable sound recordings, we have no doubt that the Yaví and Yutajé populations represent a single species.

\section{Eleutherodactylus yaviensis Myers and Donnelly \\ Figures 26-28}

Eleutherodactylus yaviensis Myers and Donnelly, 1996: 17-22, figs. 13, 14. Holotype EBRG 3017 (field no. CWM 19677), an adult female from summit of Cerro Yaví, 2150 m, Amazonas, Venezuela; collected February 22, 1995, AMNH-TERRAMAR Expedition.

?Eleutherodactylinae series b, Gorzula and Señaris, 1999: 55 (part: MHNLS 11374 [not seen], from Cerro Corocoro; collected November 10, 1987, S. Gorzula).

Material: AMNH 159161-159163, EBRG 3050-3051, from Cerro Yutajé, 1700 m, Amazonas, Venezuela; collected February 14 and February 26-28, 1995, AMNH-TERRAMAR Expedition.

In general morphology, these five specimens are very similar to the type series of Eleutherodactylus yaviensis from neighboring Cerro Yaví. But E. yaviensis was described as lacking an ear, whereas a variably flimsy tympanum was found hidden under the skin in four of the five specimens from Cerro Yutajé. The apparent absence of a tympanum in the fifth specimen gives us an excuse for not describing another species of Eleutherodactylus. Assigning these specimens to E. yaviensis, however, does require altering two character states in the definition of that species, as follow (from Myers and Donnelly, 1996: 18): (char. 2) Tympanum absent or, at least on Cerro Yutajé, often represented by a vestigial structure concealed under the skin. (char. 3) Canthus rostralis slightly concave to nearly straight.

The following description of the Yutajé frogs mirrors our original description of
Eleutherodactylus yaviensis. Except for the tympana, differences are very minor. See Remarks for discussion of the ear region.

\section{Description of the Yutajé SAMPle}

One male $20.8 \mathrm{~mm}$ SVL; four females 25.5-27.8 mm SVL $(\bar{x}=26.63 \mathrm{~mm})$. Head slightly longer than wide or as wide as long; head width $41 \%$ of SVL in the male, 40$42 \%$ of SVL in females. Snout rounded (nearly pointed in AMNH 159163) in dorsal view, rounded in profile; eye-nostril distance $72 \%$ of eye length in the male, $79-83 \%$ in females; nostrils slightly protuberant, directed dorsolaterally; canthus rostralis slightly concave or (in two specimens) straight, edge rounded; loreal region concave, sloping outward to lip. Upper eyelid with small low tubercles; upper eyelid width $93 \%$ of interorbital distance in the male, 93-100\% in females. Tympanum feebly developed, concealed beneath skin in four individuals (fig. 28, top), but apparently absent in AMNH 159162. Low glandular ridge from posterior edge of eye toward arm. Several small, inconspicuous postrictal tubercles. Choanae small, round, not concealed by palatal shelf of maxillary arch; vomerine odontophores triangular, posterior and median to choanae, bearing 2-4 teeth; odontophores as wide or slightly wider than choanae. Tongue slightly longer than wide with slight posterior notch, posterior half free. Vocal slits absent in male.

Dorsal skin granular with some inconspicuous, small scattered warts, becoming smoother in preservative; a weak middorsal raphe in the male, absent in the four females; throat smooth, venter areolate; triangular area of glandular skin present on posteroventral thigh surfaces; discoidal fold anterior to groin; ulnar tubercles absent.

Relative lengths of appressed fingers III $>$ IV $>$ II $>$ I; first finger not reaching edge of disc of finger II; male with whitish nuptial pad on posterolateral side of thumb; fingers lacking definite fringes or keels. Finger discs broader than long, rounded apically, with subdigital pads wider than long; disc on thumb slightly expanded. Palmar tubercle large and cordiform in the male and in one female (19789), divided in the rest; when divided, elongate inner portion much larger 
than small outer part; thenar tubercle oval, large; prominent subarticular tubercles round, conical; supernumerary palmar tubercles round, low or slightly protuberant, slightly smaller than subarticular tubercles.

Hind legs relatively long; heels overlap when held at right angles to the sagittal plane; tibia $53 \%$ of SVL in the male, 51$54 \%$ of SVL in females. Relative lengths of appressed toes IV $>\mathrm{V}>$ III $>$ II $>$ I; tip of toe $\mathrm{V}$ extending to distal edge of ultimate subarticular tubercle of IV, tip of toe III to the distal edge of the penultimate subarticular tubercle of IV. Toe discs broad, as broad or slightly broader than those on fingers, with wide subdigital pads. Toes lacking lateral fringes or keels, with basal webbing (I 3-3 II $2-3 \frac{1}{2}$ III $3-4 \frac{3}{4}$ IV $\left.4 \frac{1}{2}-3 \frac{1}{2} 2 \mathrm{~V}\right)$. Inner metatarsal tubercle large, elongate, about 1.8-2.6 times longer than small round outer metatarsal tubercle; small supernumerary plantar tubercles round, low to somewhat protuberant; subarticular tubercles large and round on toes I and II, protuberant on III, IV, and V; inconspicuous low calcar tubercles; tuberculation on outer side of tarsus inconspicuous or absent (more conspicuous in AMNH paratopotypes, but no tarsal fold or defined tarsal tubercle in either sample).

COLOR PATTERn: Three of the five specimens were photographed alive (fig. 26), and written descriptions were made after they were anesthetized (in chloretone solution). The dorsal ground color ranged from orangish brown (AMNH 159162) to yellowish brown. One photograph shows a faint, dull greenish tinge in one specimen (fig. 26, top), probably suggestive of the slight metachromatic changes of which these (and many other) frogs are capable. One specimen had a yellow upper lip (fig. 26, bottom). The throat was greenish gray in the male, and pale bronzy green (EBRG 3050) or bronzy white in the two females. The male had the venter and undersides of the limbs light brown, with bronze flecking on the chest; the two females had paler venters with extensive chest flecking of the same color as the throat (pale bronzy green or bronzy white). The rear of the thigh was light brown in the male, orange-red in the two females. Unlike the male, the females also had orange-red in the groin and an orange suffusion underneath the hind

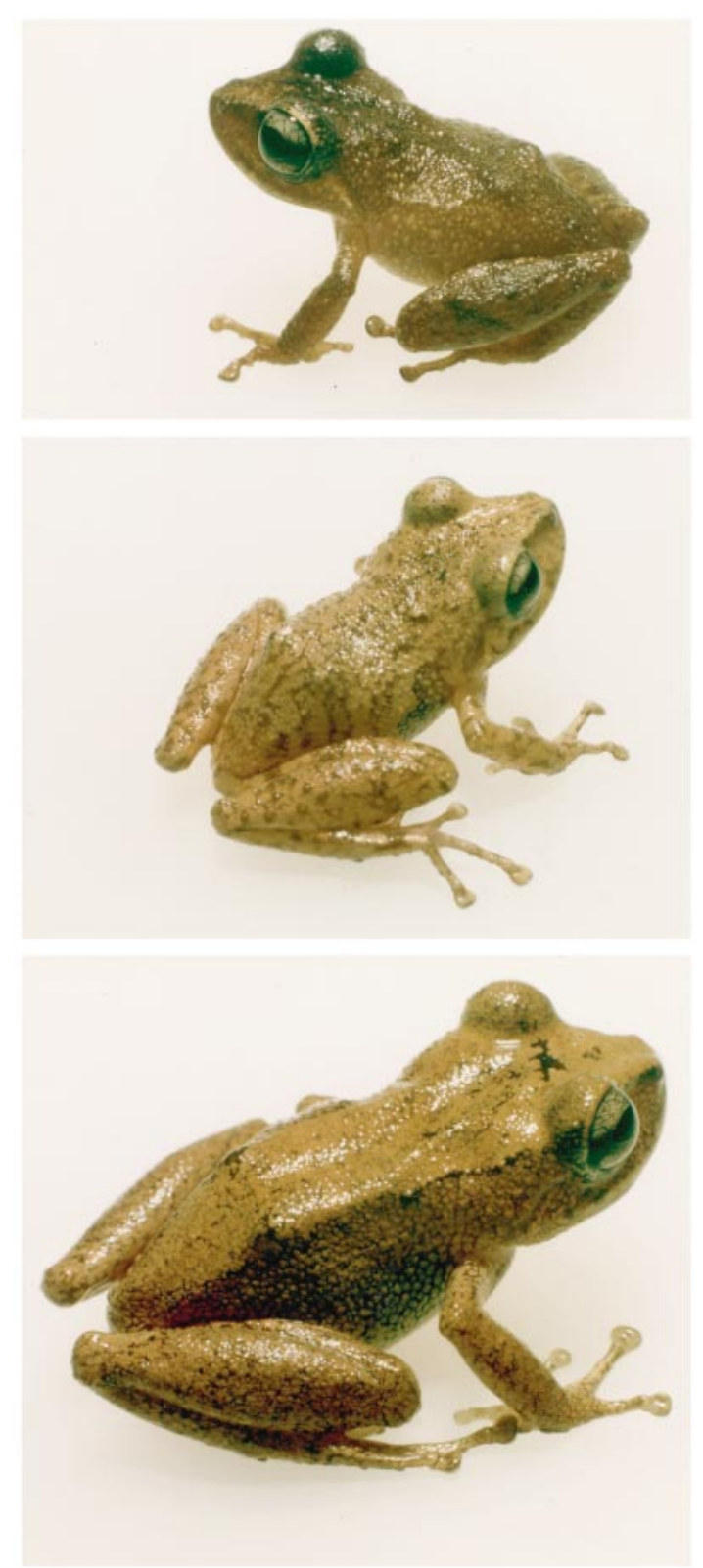

Fig. 26. Eleutherodactylus yaviensis Myers and Donnelly, from Cerro Yutajé, 1700-m camp (not to same scale). Top: Adult male, $21 \mathrm{~mm} \mathrm{SVL}$ (AMNH 159161. Middle: Adult female, $26 \mathrm{~mm}$ SVL (EBRG 3050). Bottom: Adult female, 28 mm SVL (AMNH 159162). 


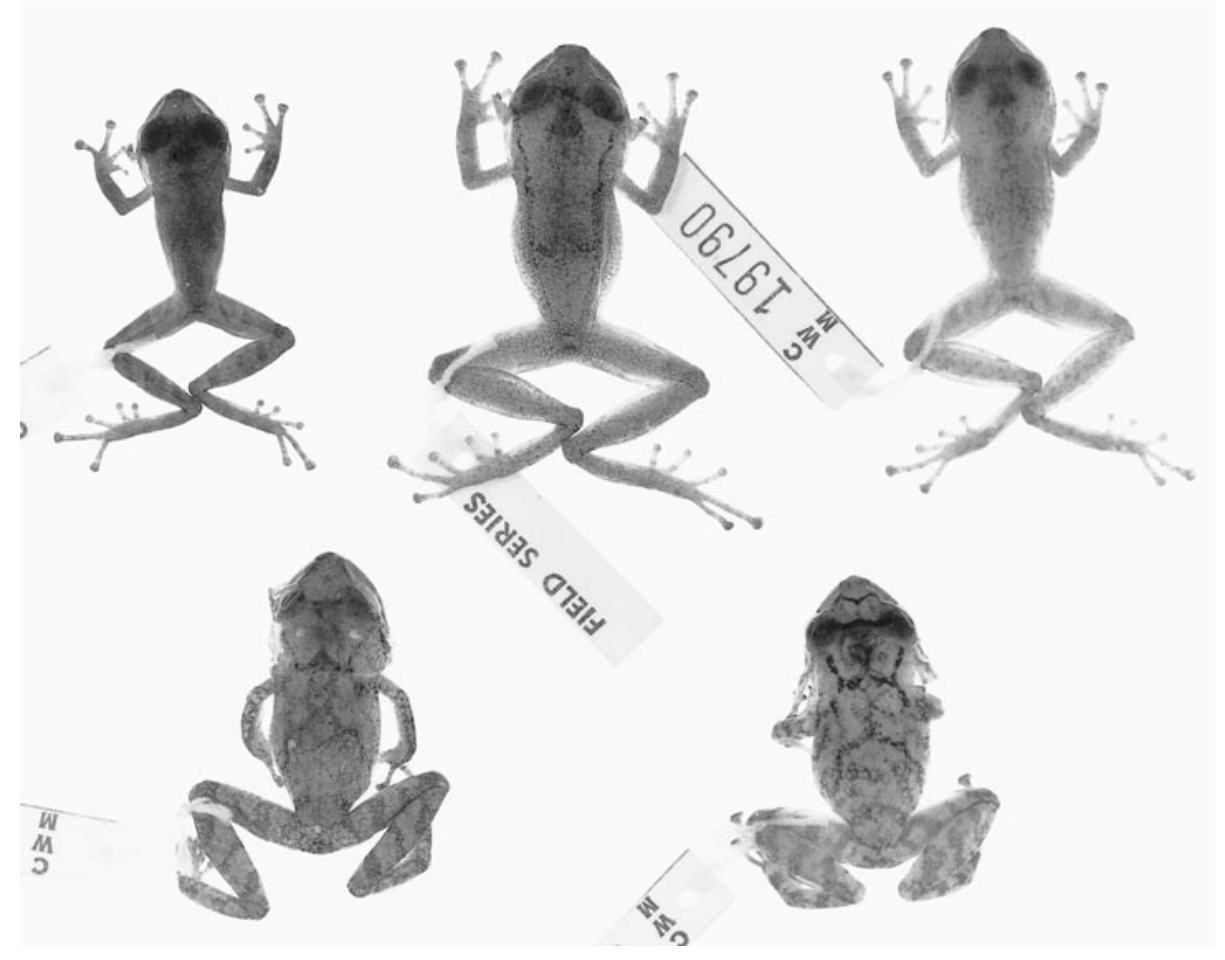

Fig. 27. The sample of Eleutherodactylus yaviensis from Cerro Yutajé, $\times 1.1$. Left to right, top to bottom: AMNH 159161 ô, 159162 , EBRG 3050 $q, 3051 \%$, AMNH 159163 ․

legs. The iris was pale gray in the male, or overall bronzy tan in one female, or bronzy green above and pale gray below in the other female (EBRG 3050), but all had inconspicuous black venation and a reddish brown horizontal stripe.

In preservative (fig. 27), the dorsal ground color of all five frogs varies from brown in the male to light tan in the females. An illdefined dark stripe below the canthus rostralis also is visible in photographs from life (fig. 26), as are vague dark brown dorsolateral lines in one specimen (AMNH 159162). Two females (EBRG 3051, AMNH 159163) each have a W-shaped dark mark on the scapula; one (AMNH 159163) of these also has a distinct interorbital bar, a small Vshaped mark anterior to the interorbital bar, and vague chevrons posterior to the scapular W-shaped mark. Crossbars on the limbs vary from vague to distinct. All the preserved specimens have a variably developed (vague to distinct) dark line extending from the rear edge of the eye toward the arm insertion. Granules on the anterior flank tend to be un- pigmented and to form the pale centers of a variably distinct dark reticulum. The upper lip has a dusky appearance owing to the density of melanophores, but one specimen has a pale, poorly defined stripe that was yellow in life (fig. 26, bottom); a few others have vague dark markings suggestive of incipient lip bars (fig. 26, middle). Most subarticular, palmar, and plantar tubercles are pigmented, although some are not.

\section{NATURAL History}

Three frogs (AMNH 159161-159162, EBRG 3050) were found at night during February 26-28 on low vegetation in wet, mossy forest near the 1700-m camp. Two others (AMNH 159163, EBRG 3051) were found in bromeliad tanks (Brocchinia) by entomologists, who were working out of this camp on February 14. Eleutherodactylus yaviensis was less common at $1700 \mathrm{~m}$ on Cerro Yutajé than in the cooler forest at $2150 \mathrm{~m}$ on Cerro Yaví, whereas the reverse situation pertained to $E$. cantitans. 


\section{REMARKS}

Four of the five frogs in the sample from Yutajé have a feebly developed ear that is concealed beneath the skin. This has caused us to worry that we may be confounded by having two sibling species in our small $\mathrm{Yu}$ tajé sample, with the one earless specimen perhaps representing E. yaviensis and the others being undescribed. In describing $E$. yaviensis, we dissected only a few specimens to confirm absence of the tympanum, but in view of the Yutajé situation, we subsequently have examined all the AMNH paratopotypes ${ }^{17}$ from Cerro Yaví in order to determine if there is variation in that sample. Comparisons of the ear region between the Yaví and Yutajé samples follow.

Cerro Yaví: There are 13 paratopotypes of Eleutherodactylus yaviensis at the American Museum; in all, the ear region on the left side was exposed. None have a tympanum or any obvious vestige that we can identify, but there is interesting variation in the disposition of the $\mathrm{m}$. depressor mandibulae. Some specimens have it as shown in figure 28 (bottom), in which the anterior edge of this muscle superficially appears to originate from the epimysium of the adductor mandibulae muscle. But the fibers in the anterior part of the depressor mandibulae actually originate from a thin white tendinous edge that overlaps and lies close to the adductor mandibulae, and which may be anchored by one or more connective-tissue attachments to the adductor mandibulae. Other specimens (e.g., AMNH 143372, both sides dissected) show a distinct gap between the lower posterior part of the $\mathrm{m}$. adductor mandibulae and the anterior tendinous edge of the $\mathrm{m}$. depressor mandibulae. The anterodorsal part of the depressor mandibulae seems to originate partly from the zygomatic ramus of the squamosal bone. The tendinous anterior edge inserts on the mandible.

Cerro Yutajé: Figure 28 (top) shows the best development of the tympanum among the four specimens that have it. A portion of the $\mathrm{m}$. depressor mandibulae originates from the posteroventral part of the tympanic ring; the posterodorsal part of the tympanum is

\footnotetext{
17 The holotype and other paratopotypes had already been deposited in the EBRG collection in Venezuela.
}

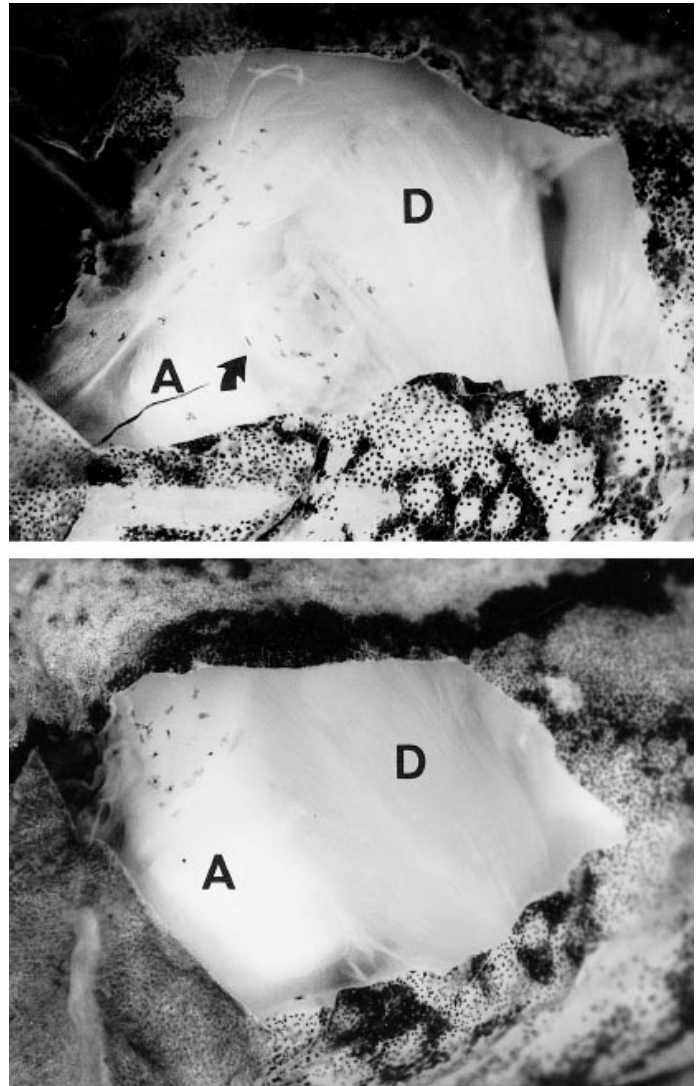

Fig. 28. Ear region of Eleutherodactylus yaviensis. Top: Concealed tympanum (arrow) in specimen from Cerro Yutajé (EBRG 3051). Bottom: Absence of the ear in a paratopotype from Cerro Yaví (AMNH 143374). Abbreviations: A = $\mathrm{m}$. adductor mandibulae; $\mathrm{D}=\mathrm{m}$. depressor mandibulae.

tipped under the edge of the depressor mandibulae. The tympana are flimsier in three other specimens, only two (AMNH 159161, EBRG 3050) of which have a slip of depressor mandibulae originating apparently from the tympanic ring.

A very faint vestige of the tympanum could be seen with careful lighting in AMNH 159163; it evidently is too weak a structure for anchoring part of the depressor mandibulae, which originates instead from the adductor mandibulae. A tympanum was not detected in AMNH 159162, although there is an equivalent-sized cavity; as in the preceding specimen, part of the depressor mandibulae originates directly from the epimysium 
of the adductor mandibulae rather than from a tympanic ring. A tendinous edge along part of the anterior depressor mandibulae (as mentioned above) was noticed in a few specimens and might be present in all.

OTHER CONSIDERATIOns: Museum specimens of pattern-polymorphic, sympatric species of Eleutherodactylus can be exceedingly hard to differentiate, although differences in body and iris coloration in life often help to distinguish them in the field (e.g., see commentary on $E$. avius and $E$. memorans in Myers and Donnelly, 1997: 58).

Excluding the ear character for the moment, the diagnostic characters shared by $y a$ viensis and the Yutajé specimens include orange or red flash marks in groin, anterior and posterior thigh, and concealed part of shank (the flash color is suffused, without sharply defined edges). The flash color was absent in life in the one male from Yutajé, as well as in six small frogs from Cerro Yaví. The field catalogue mentions a bronzy aspect to the throat and bronze chest flecking for specimens in both populations. Iris color was variable in both samples, except for the constant feature of a reddish brown horizontal stripe through the pupil.

Color features that tend to disappear in preservative are at least consistent with our hypothesis that a single species is represented. Color pattern itself is so variable, and the Yutajé sample so small, that any significant differences cannot be determined. The conspicuous W-shaped scapular marking in two specimens from Yutajé (fig. 27) is not mentioned in our description of variation in $E$. yaviensis, although the associated dark chevrons were reported as occurring. However, one of the paratopotypes (AMNH 143371) dorsally has a large oblong marking with thin anterior extensions that precisely match the outer legs of the "W" mark in the two Yutajé specimens. A dark reticulum on the anterior flank is conspicuous in a few specimens from each sample.

In summary, we cannot satisfactorily separate the Yaví and Yutajé samples in any consistent way, nor can we convince ourselves that the one earless Yutajé specimen represents a taxon different from the ones with tympana. We imagine that there must be a taxonomic purgatory ${ }^{18}$ for those who carelessly and thoughtlessly establish unnecessary nominal species of Eleutherodactylus, and we therefore treat the specimens from the Yutajé-Corocoro massif as representing a partially differentiated population of Eleutherodactylus yaviensis. Insofar as we are aware, however, intrapopulational variation in presence or absence of tympana has not been reported for any other species in the genus.

The one amphibian taken by Gorzula on Cerro Corocoro in 1987, at $2150 \mathrm{~m}$, was included with several other unidentified montane frogs under "Eleutherodactylinae series b" by Gorzula and Señaris (1999: 55, 255). Among aspects of its color in life were "dorsum a light-brown filigree over a golden cream base color ... upper lip with a pale yellow line [and] brown subarticular tubercles.' One of our specimens (fig. 26, middle) has a light brown reticulum over a lighter base, another one (fig. 26, bottom) has a yellow lip stripe, and all tend to have pigmented subarticular tubercles, leading us to suggest that Gorzula's frog is a specimen of Eleutherodactylus yaviensis as here defined.

\section{Pseudopaludicola llanera Lynch Figures 29, 30}

Pseudopaludicola llanera Lynch, 1989: 583. Holotype ICNMHN 13576, from Puerto Gaitán, Depto. Meta, Colombia, collected June 8, 1984 by Olga V. Castaño and Maria C. Ardila.

MATERIAL: AMNH $159165 \%, 1591660$,

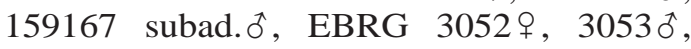
3054 subad. $\hat{0}$, from rocky stream north of conical peak on south end of Cerro Corocoro, $1220 \mathrm{~m}\left(5^{\circ} 42^{\prime} \mathrm{N}, 66^{\circ} 10^{\prime} \mathrm{W}\right)$. Of the six specimens, two are adult females (enlarged oviducts and large pigmented ova) 16.2 and $16.5 \mathrm{~mm}$ SVL, two are adult males (vocal slits open) 13.4 and $13.8 \mathrm{~mm} \mathrm{SVL}$, and two are juvenile or subadult males (testes well

\footnotetext{
18 Thomas Barbour (1928: 25) conveyed a similar sentiment when he wrote that "It seems wicked and sinful in this day and generation to describe new species of Eleutherodactylus." G. Kingsley Noble seemed not to enjoy receiving preserved specimens for identification, as suggested by his private generic synonym "Eleutherodactylice" (Myers, 2000: 40). It is a large genus, with over 500 named species.
} 


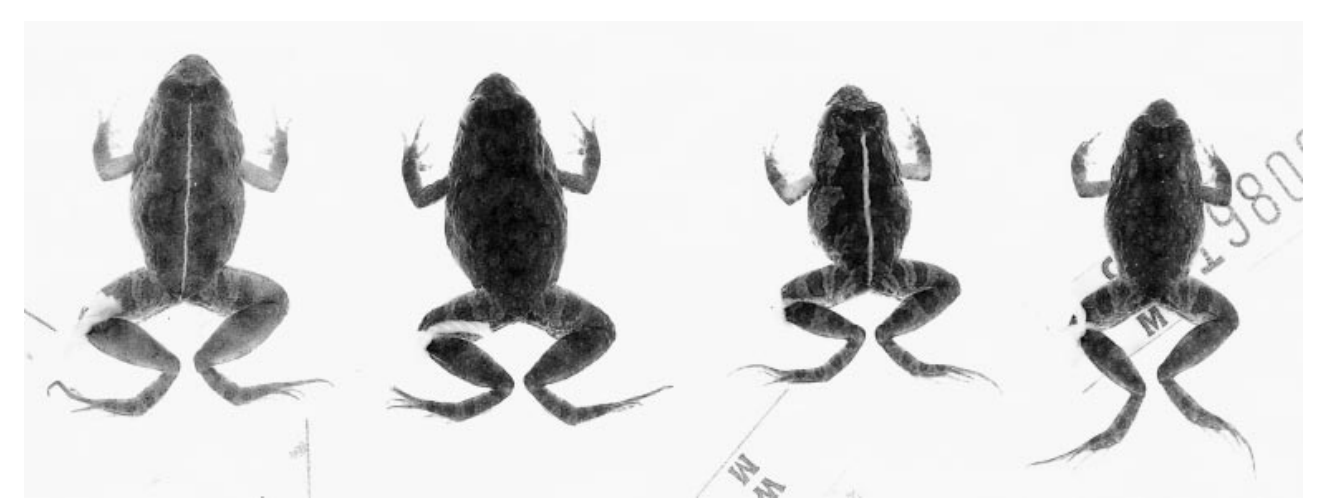

Fig. 29. Pseudopaludicola llanera Lynch, $\times 1.6$. Pattern polymorphism in sample from $1220 \mathrm{~m}$

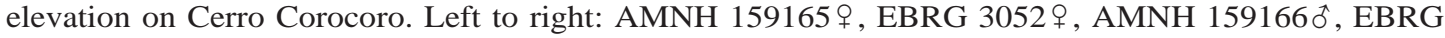
3053 o.

developed but vocal slits not opened) 12.1 and $12.6 \mathrm{~mm}$ SVL.

\section{DESCRIPTION OF SAMPLE}

The following account, which excludes characters common to the pusilla species group sensu Lynch, closely mirrors Lynch's (1989) description of $P$. llanera, which he established on the basis of 23 specimens in the type series (some 50 additional specimens were referred to the species in his list of specimens examined). Disparities with Lynch's description are shown in italics (see Remarks).

Snout acuminate or subacuminate in dorsal view (fig. 29); interorbital space flat and narrow (narrowest part 71-92\% of median width of upper eyelid, as follows: $71-75 \%$ in two subadult males, $77-83 \%$ in two adult males, and $86-92 \%$ in two adult females). Skin of dorsum bearing various-sized, low ("flattened") warts with smoothly rounded surfaces, with degree of tuberculation possibly reflecting sexual dimorphism as well as differences attendant with preservation. The adult female in life (fig. 30, top) was clearly tuberculate over the body, and also had a few small warts on the upper eyelid, although the top of the snout appears smooth in the photograph. In preservative, however, the skin of the two females is somewhat smoother over the body than in life, with the eyelid warts inconspicuous and the top of the snout being quite smooth in the photographed specimen and very weakly tuberculate in the other one. In contrast, all four males in preservative have the eyelids and the top of the snout markedly tuberculate; more subjectively, the males also seem more tuberculate on the body when compared with the preserved females.

All specimens with two distinct antebrachial tubercles, the distal one largest. Adult males with large vocal slits and unpigmented nuptial asperities on base of thumb.

An indistinct to distinct low rounded tubercle on upper edge of heel (but not projecting and pointed as in most $P$. boliviana). Row of minute, inconspicuous tubercles along outer edge of tarsus (not evident in AMNH 159165). Outer metatarsal tubercle conical, small but nearly as long as the protuberant inner metatarsal tubercle. Toe tips round, not expanded, lacking clearcut terminal groves, although an occasional toe shows a faint trace of a terminal groove under high magnification. Toes bearing distinct lateral fringes, but no basal webbing (discounting basal fusion of lateral fringes between toes). Tibia $46-51 \%$ of snout-vent length, with indication of the expected ontogenetic change and sexual dimorphism (tibia/SVL $=0.46,0.46$ in adult males, 0.50, 0.51 in subadult males, and $0.49,0.50$ in adult females).

Color-pattern polymorphism present. In life, dark brown or grayish brown above, with or without a pale grayish vertebral line in each sex. In preservative (fig. 29), a wavyedged brown dorsal band is conspicuous in the male and female with pale vertebral lines, and is faintly indicated in the other adult 
male; the other females and the subadult males are overall dark without a definite pattern except for crossbars present on the limbs of all specimens. Throat and venter white and undersides of limbs light gray in life; throat, chest, and anterior venter sparsely to heavily flecked with dark pigment, with sparse to moderate flecking on undersides of thighs. Rear of thighs dark brown below crossbars, but this pigment not forming "a dark line along lower edge of posterior surfaces of thighs"; several specimens with the dark pigment forming an ill-defined brown stripe along anterior side of thigh. The iris was grayish with brown suffusion. The base of the tongue is very weakly "pigmented" (see Lobo, 1995, character 15) with a few to several melanophores, except in EBRG 3052, which lacks melanophores.

\section{NATURAL History}

These miniature frogs were taken by day from sparse aquatic vegetation in shallow water along the edge of a drying, boulderstrewn stream (fig. 5, bottom). Some tiny eggs (not preserved) were found in a plastic bag containing only AMNH 159165, but it was not clear whether the eggs had been picked up unnoticed with the frog or laid in the bag overnight. The stream is near the base of the conical peak seen in several photographs (e.g., fig. 5, top). This part of the Yutaje-Corocoro massif is well drained and seasonally arid.

\section{REMARKS AND COMPARISONS}

Although the specimens were collected on a relatively low and arid part of the YutajéCorocoro massif, the occurrence of Pseudopaludicola at an elevation of $1220 \mathrm{~m}$ was nonetheless unexpected. The few differences between Lynch's description of Pseudopaludicola llanera and the present specimens are assumed not to have taxonomic significance, but to merely extend the range of variation in P. llanera. Concerning Lynch's original concept of this species as being monomorphic in color pattern, he and colleagues (Ruiz-Carranza et al., 1996: fig. 83) subsequently published a photograph of a living female specimen that has a pale vertebral line like the one in figure 30 (top), and Gorzula and Señaris (1999: 81) mentioned the existence of three basic color morphs in Venezuela.

The Cerro Corocoro sample described above was compared with a series of $\mathrm{Pseu}$ dopaludicola (AMNH 100614-100633) collected by Myers and Daly on February 2627, 1978, in the lowlands (100 m) at Santa Bárbara, junction of the Río Ventuari with the Río Orinoco-some $200 \mathrm{~km}$ to the southsouthwest. Fieldnotes for this series read that the frogs were

Active by day (disappearing at night) on muddy bank of a drying caño near its entrance into the Orinoco. Very much like cricket frogs (Acris) in their behavior and habitat and appearance: i.e., small diurnal frogs, active on muddy banks, showing pronounced pattern polymorphism, and hopping about like crickets when pursued.

The 20 specimens in this series seem to represent a composite of two sibling species, which were not differentiated in the field and which may differ most noticeably in size. Two of the specimens are assigned to Pseudopaludicola, species inquirenda, and the others represent $P$. boliviana Parker, sensu Lynch, thus providing an interesting instance of microsympatry in the genus despite the problems of identification.

Pseudopaludicola boliviana: As currently recognized, this species ranges from Bolivia, Paraguay, and Brazil north to Guyana, southern Venezuela, and eastern Colombia (Lynch, 1989; Lobo, 1994) — a distribution suggesting the likelihood of boliviana being a composite species in need of critical review, particularly when bioacoustical and additional data become available (Lynch [1989: 581] mentioned the problem of distinguishing preserved specimens "from one another, in spite of the vast geographic distances between localities"). The present Venezuelan sample (AMNH 100615, 100617-100633) reveals variation in the diagnostically useful antebrachial tubercles and in the conical heel tubercle (see below).

Pseudopaludicola boliviana is a small frog. There are two presumed adult males (vocal slits open) 11.7 and $12.1 \mathrm{~mm} \mathrm{SVL}$, and two slightly larger males of 12.2 and $12.9 \mathrm{~mm}$ SVL that lack vocal slits. Four ju- 


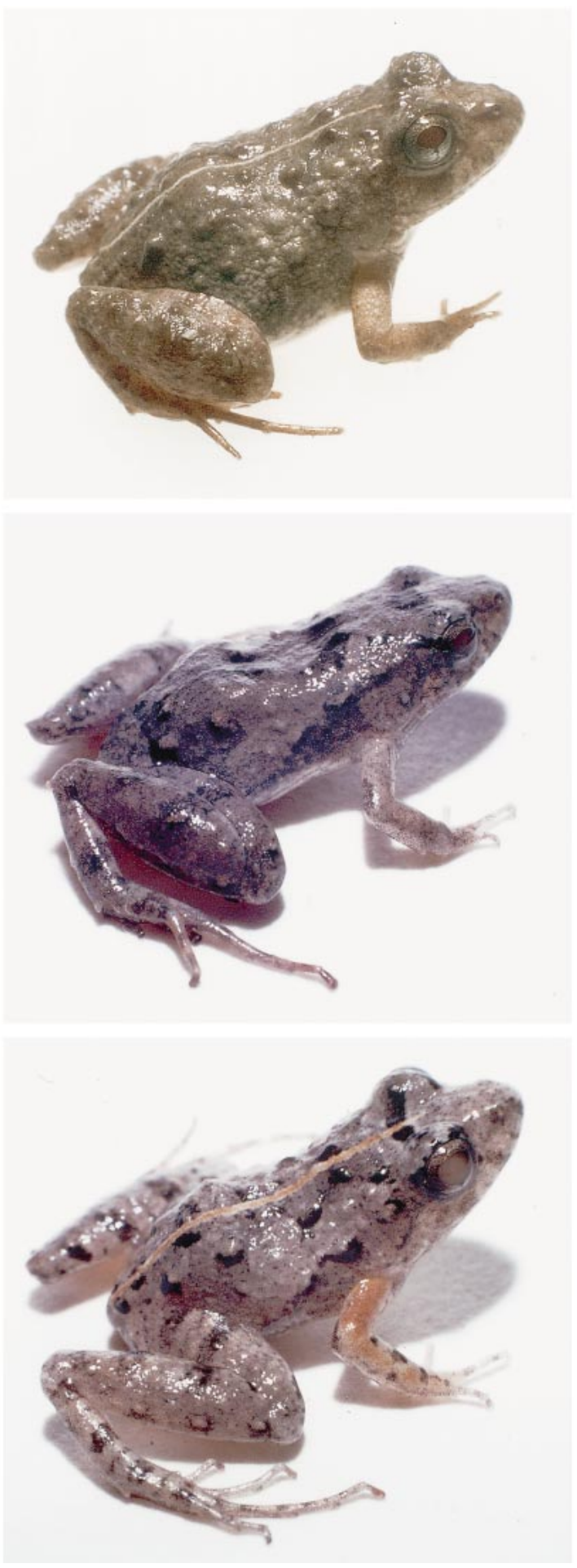

Fig. 30. Southern Venezuelan species of Pseudopaludicola (not to same scale). Top: Pseudopaludicola llanera Lynch. Adult female venile females (with threadlike oviducts) are 9.4-11.1 mm SVL. The remaining $10 \mathrm{spec}-$ imens are sexually inactive females $12.0-$ $13.7 \mathrm{~mm} \mathrm{SVL}(\bar{x}=12.84 \mathrm{~mm})$; these have convoluted albeit small oviducts and lack enlarged ova. The interorbital space is relatively wide $-0.91-1.44 \%(\bar{x}=1.10 \%, N=18)$ of the width of an upper eyelid. ${ }^{19}$ The tibia is $50-56 \%$ of SVL in the four males and $51-$ $55 \%$ in 10 adult or subadult females (54$57 \%$ in the four juvenile females). In life, frogs are mostly gray above with vague darker gray markings; a male and a female each had a conspicuously contrasting vertebral line of pale tan, and another female shows a faint hairline in preservative. Four females (AMNH 100630-100633, which include 3 of the 4 juveniles) had the distal two-thirds of the head and body uniformly reddish brown, with this color being sharply demarcated at its posterior margin; in preservative, these specimens also have faint indication of a pale vertebral hairline and also faint indication of dark smudging on the anterior dorsum. Ventral surfaces were white, with some variable but mostly inconspicuous dark speckling.

\footnotetext{
${ }^{19}$ In preserved specimens of these tiny frogs, there often is no clear demarcation to the medial side of the upper eyelid. Therefore, the eyelid and the interorbital distance are subject to significant measuring error, which is why statistics are not separately given for males and females in the small sample at hand. The character Eyelid/IOD nonetheless is of some use in species comparisons (see Lynch, 1989: table 1).
}

(AMNH 159165, $16.5 \mathrm{~mm}$ SVL) from $1220 \mathrm{~m}$ elevation on Cerro Corocoro. Middle: Pseudopaludicola boliviana Parker. Adult or subadult female (AMNH 100615, $13.7 \mathrm{~mm}$ SVL) from Santa Bárbara, 100 m. Bottom: Pseudopaludicola, species inquirenda. Juvenile female (AMNH 100614, $14.0 \mathrm{~mm}$ SVL) also from Santa Bárbara. These photographs help to visualize certain diagnostic characters. Note the narrow tips of the toes in $P$. llanera vs. the weakly expanded toe tips in the other two. $P$. boliviana usually has a conical tubercle on each heel (see left side; right side shows a bit of debris), and the interorbital space is relatively wide. The possibly unnamed species in the lower photograph has expanded toe tips but lacks a heel tubercle, and it seemingly is a larger species than $P$. llanera or $P$. boliviana (see text). 
Among the suite of diagnostic characters that help identify Pseudopaludicola boliviana are a conical heel tubercle and a relatively wide interorbital space, both of which are visualized by reference to figure 30 (middle). But the interorbital space is unfortunately hard to quantify, and the heel tubercle is evidently subject to some variation. The heel tubercle was coded as present on both heels in 14 of the 18 specimens, as present on one heel only in three specimens, and as absent in one juvenile female (AMNH 100623). The tubercle seems rather fragile, and its occasional absence or blunted appearance may be due to damage or abrasion. For example, the frog shown in figure 30 (middle) is seen to have a noticeably pointed tubercle on the left heel, but this tubercle seems smaller and is blunted in the preserved specimen; the tubercle was coded as absent on the right heel of this specimen, although an indication of it is arguably present at high magnification (the photograph shows what seems to be a bit of debris on the right heel).

About half the specimens have a single antebrachial tubercle, as is supposedly characteristic of $P$. boliviana, but many also have a slightly elevated posterior tubercle; there may also be indication of a few smaller accessory tubercles in line with the larger ones (e.g., AMNH 1006240). In any case, the antebrachial tubercles are less elevated than in the highland frogs assigned above to P. llanera. Pseudopaludicola boliviana also is said to be characterized by basal foot webbing, but it is not evident in this sample; basal fusion of toe fringing makes determination of basal webbing especially subjective in species such as $P$. boliviana and P. llanera (see Lynch, 1989: figs. 2B, 2D); toe fringing in the present sample seems less developed than in $P$. llanera above. All specimens have the toe discs slightly expanded in contrast to $P$. llanera.

Pseudopaludicola, species inquirenda: There are two specimens (AMNH 100614 \% $\left.1006160^{3}\right)$ that were not distinguished from $P$. boliviana in the field. They were both gray with blackish markings and a tan or pale brown vertebral line (fig. 30, bottom). The interorbital space is about $85 \%$ ( $\sigma^{*}$ ) and $92 \%$ ( $q$ ) of upper eyelid width, and the tibia is $47 \%$ (o) and $53 \%$ ( $q$ ) of SVL. There are two weak antebrachial tubercles, but no conical heel tubercles.

The female, at $14 \mathrm{~mm} \mathrm{SVL}$, has threadlike oviducts and is therefore judged to be a juvenile, although it is slightly larger than the largest females in the sympatric sample of $P$. boliviana. The male, at $15.9 \mathrm{~mm}$, is an adult with well-developed vocal slits and black testes; it is about $19-27 \%$ larger than the four male boliviana. This specimen also is 13-16\% larger than the two adult male llanera from Cerro Corocoro, and direct comparison makes it seem unlikely that a single species is involved (the juvenile female is uninformative, being smaller than the adult female llanera).

Despite the size difference, we would be inclined to assume interpopulational variation and assign these specimens to Pseudopaludicola llanera. However, in marked contrast to llanera, the toe tips are slightly but definitely expanded to about the same degree as the sympatric specimens of boliviana, and, similarly, these two specimens and sympatric boliviana have the distal antebrachial tubercle somewhat less pronounced than in llanera. Thus, we suspect that these two specimens represent a third species of Pseudopaludicola in southern Venezuela.

Specimens from the same locality (Santa Bárbara) were referred to Pseudopaludicoa llanera by Gorzula and Señaris (1999: 81), leaving open the possibility that the postulated three southern Venezuelan species all occur in sympatry. But it seems conceivable that at least some of their specimens may represent the presumably undescribed sibling species as well as $P$. boliviana. Specimens collected by Gorzula at Santa Bárbara might be from a different microhabitat than the mixed sample of $P$. boliviana and species inquirenda reported here, but his material was obtained in the same week as those specimens, and on the same expedition. ${ }^{20}$

\footnotetext{
${ }^{20}$ The 1978 CODESUR-American Museum Expedition to Cerro Yapacana, in which Gorzula participated, used Santa Bárbara as a starting place for boat travel. Dr. Otto Huber served as expedition leader and coordinated the unpublished expedition report (see Myers, 2000: 157-158).
} 


\section{LIZARDS}

FAMILY TEIIDAE

The diverse genera of "microteiids" are sometimes placed in a family (Gymnophthalmidae) separate from their larger relatives ("macroteiids"), but the reasons for so doing are either based on undocumented characters, incomplete data, or on authoritarianism. In critically examining a claim by Presch (1983) that macroteiids and microteiids are not related, Harris (1985: 564) presented very persuasive evidence in support of their "exclusive common ancestry". Harris further concluded that available evidence does not confirm that the microteiids themselves comprise a single natural (monophyletic) group. This level of knowledge has not changed since 1985 .

The matter of authoritarianism comes in with the impressive work of Estes et al. (1988), which was influenced (see p. 142 of their Character Analysis) by the flawed work of Presch (see Harris, 1985). Even though Estes et al. confirmed teiid monophyly, they nonetheless, according to Myers and Donnelly (1996: 21-22),

continued the separate family arrangement for no obvious reason except that one of them (Estes) also had earlier recognized the Gymnophthalmidae-based on synapomorphies that "were for the most part variable characters" (Estes et al.: 217). The newer lists of putative synapomorphies (Estes et al.: 215-217) for the macroteiid and microteiid "families" are based on an unknown (unstated) number of genera and species and their extrapolated use requires perhaps more faith than should be necessary.

The following additional remarks are in response to a reviewer's suggestion that we should perhaps follow the authority of Estes et al. in the matter of teiid classification, inasmuch as they provided supporting synapomorphies.

However, except for one unequivocal character (anterior nasal scales separated by one or two frontonasals) dating from Boulenger, one cannot usually tell how many microteiid genera or species have been checked for the synapomorphies listed by Estes et al. (1988: 217) - there is no summary of evidence. Furthermore, among the 12 putative synapomorphies given by Estes et al. for mi- croteiids, there are other problems involving either accuracy or pragmatism, as in the following examples.

The presence of frontal tabs projecting posteriorly over the parietal bone was given by Estes et al. (1988: 144, 217) as a defining synapomorphy of microteiids (with independent acquisition only by some chamaeleontids) - overlooking the observation by Harris (1985: 564) that frontal tabs occur also in at least one macroteiid genus and that the condition may simply be easier to see in small teiids. Another purported synapomorphy given by Estes et al. is "descending processes of frontals in contact below olfactory tracts", which condition, however, is displayed only in "some" gymnophthlamids (Estes et al., 1988: 144; see also Harris, 1994: 229).

The common derived squamate condition of "second epibranchial lost" was listed as a microteiid synapomorphy by Estes et al. (1988: 164, 217) on the authority of Camp (1923), MacLean (1974), and Presch (1980). However, Camp (1923: 339) only said that the "second epibranchial is apparently absent and the second ceratobranchial is still present" in a specimen of the microteiid Bachia, whereas neither MacLean nor Presch explicitly stated that the second epibranchial was lost in microteiids. MacLean (1974: 191192), in fact, wrote that "Many Gymnophthalminae have disjunct epi-elements, one portion attached to the cerato-element and the other to the braincase." Presch (1980) dealt only with the loss in some microteiids of the second ceratobranchial (note reversal of labels in his fig. 5).

Two character states ("frontals fuse in embryonic or early postembryonic ontogeny", and "parietal foramen lost") in the synapomorphy list in Estes et al. (1988: 217) are, according to the text (pp. 143, 148), indistinguishable from the usual conditions in macroteiids (the first character also was given [p. 215] as a synapomorphy for macroteiids based on interpretation of fossil evidence).

The apparently derived character of "calcified spines embedded in hemipenial flounces" (Estes et al., 1988: 142) describes what seems to be the usual condition in microteiids. However, whether this is synapomorphic for all microteiids or only a large subset is very much open to question. In the 
case of in-group variation, Estes et al. (1988: 142) tended to interpret "the derived state as plesiomorphic for that taxon." In this case, that assessment would have agreed with Presch's (1983: 192) conclusion that absence of "definite folds and teeth [hemipenial spinules]" is a secondary loss in microteiids, based on his earlier descriptions of unornamented hemipenes in Bachia and Anadiaan observation perhaps conceivable for the first genus but in error for the last one. ${ }^{21} \mathrm{Cal}-$ careous spinules, however, are absent in the hemipenes of Alopoglossus and Ptychoglossus, which "possibly comprise a sister group to all other microteiids" (Harris, 1994: 229). The new genus Adercosaurus, described below, also lacks series of comblike calcareous spinules, and it may be that the absence of such spinules represents the plesiomorphic condition for microteiids.

As suggested above, it remains to be determined whether any of the purported microteiid synapomorphies (other than separated nasal scales) can be used to define anything other than various subsets of small teiids. The division between larger and smaller-macroteiids and microteiids-is a convenience for taxonomic discourse without the burden of formal nomenclature. MacLean (1974) separated teiids into the new subfamilies Teiinae and Gymnophthalminae; his action recognized the monophyly of the Teiidae and was not an unreasonable hypothesis for its time. Estes (1983: 74-75, 97) and Presch (1983) independently elevated MacLean's subfamilies to family rank, with a major difference-Estes considered them as sister

\footnotetext{
${ }^{21}$ Presch (1978) examined and described everted microteiid hemipenes without realizing that some had been only partially everted in the field. Thus, an organ of Anadia metallica $(=$ A. ocellata) was described and illustrated as a smooth bulbous structure, with a dimpled tip (almost always an indication of incomplete eversion). The hemipenis of this species is in fact bilobate with comblike rows of calcareous spinules (observation based on everted hemipenes of AMNH 114306 and 129779 from western Panama).

Also described as smooth were the illustrated organs of two species of Bachia (a genus characterized by loss of the external ear and trends toward loss or reduction of various head scales and limb elements). However, these hemipenes also may be incompletely inflated, and they need reexamination in order to confirm degree of eversion and absence of spinules.
}

groups, whereas Presch considered them to be unrelated to one another. Presch's reasoning was discredited by Harris (1985), who pointed out errors of fact and provided convincing proof of monophyly for the two groups. The argument for monophyly was subsequently supported by Estes et al. (1988), who also discounted (on p. 217) the gymnophthalmid synapomorphies earlier given by Estes (1983) as being "for the most part variable characters". Nonetheless, Estes et al. continued recognizing macro- and microteiids as separate families on the basis of other purported synapomorphies, which, upon examination, start to disintegrate into those objectionable "variable characters".

Macroteiids and microteiids may indeed differ in some fundamental way yet to be elucidated, and it is at least conceivable that the single character of separated nasals might be corroborated in a way that will demonstrate the monophyly of all microteiids. But in the face of inadequately presented data, insufficient character analysis, and uncorroborated hypotheses, we join Harris (1985) and Cole et al. (1990: 2) in preferring nomenclatural caution when change is neither mandatory nor purposeful.

Venezuela has a rich teiid fauna, with 45 species disposed in 18 genera as of 1997 , which compares with 42 species in 21 genera in the much greater area of Brazilian Amazonia (La Marca, 1997; Avila-Pires, 1995). In each region, microteiids comprise about three-quarters of the teiid species diversity.

One of two species of microteiids from the Yutajé-Corocoro massif does not fit in any teiid genus known from the Guayana region, nor can we place it in any of the extralimital genera. Accordingly, the following generic name is proposed as a hypothesis of distinctiveness of this newly discovered lizard (figs. 31, 32).

\section{Adercosaurus, new genus}

Type SPECIES: Adercosaurus vixadnexus, n. sp.

ETYMOLOGY: From the Greek aderkes (something unexpected or unseen) + sauros-an unexpected lizard. Gender masculine.

Content: Monotypic. 

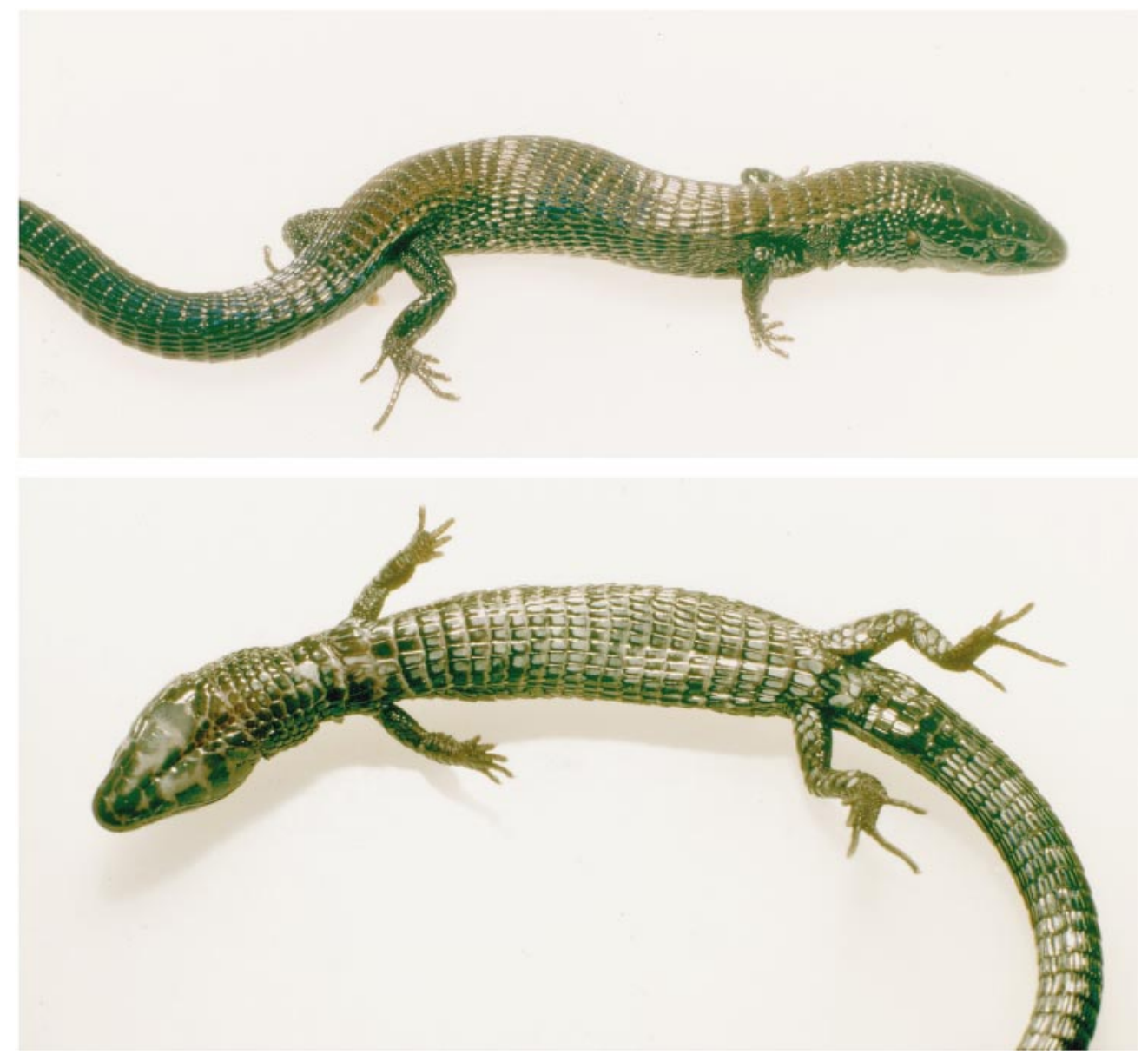

Fig. 31. Adercosaurus vixadnexus, new species. Views of the holotype in life (EBRG 31260 , 55 mm SVL).

Definition and Diagnosis: Small lizards, maximum size probably less than $80 \mathrm{~mm}$ SVL, with tail probably less than twice body length. Tongue anteriorly and posteriorly bearing oblique, anteriorly converging plicae, with intervening midsection of imbricate scalelike papillae; three pairs of nonswollen chrevron-shaped infralingual plicae. Pterygoid teeth present. Phalangeal formulae 2-34-5-3 for hands, 2-3-4-5-4 for feet. Hemipenis lacking spines or spinules, symmetrically bifurcate, with thickened, lobate apical discs; asulcate side of hemipenis with encircling nude ridges. Head scales smooth. Nasal scales separated by rostral and undivided frontonasal. Loreal separated from labials by frenocular. Supraoculars separated from eye- lids by a complete superciliary series; anterior superciliary large, not expanded dorsally. Translucent palpebral disc composed of about six vertical panes. Frontoparietals medially in point contact. Interparietal longer than parietals, their common sutures forming a jagged line across rear of head. Tympanum slightly recessed, lightly pigmented. Single postmental scale followed by three pairs of genials in contact with labials. Anterior gular crease, incomplete guttural fold, and collar fold all conspicuous. Paramedian gulars enlarged, in short double row. Dorsal and lateral scales elongate with parallel sides, hexagonal, in transverse rows only; dorsals sharply keeled, strongly mucronate, laterals becoming less so. Lateral fold absent, a gra- 

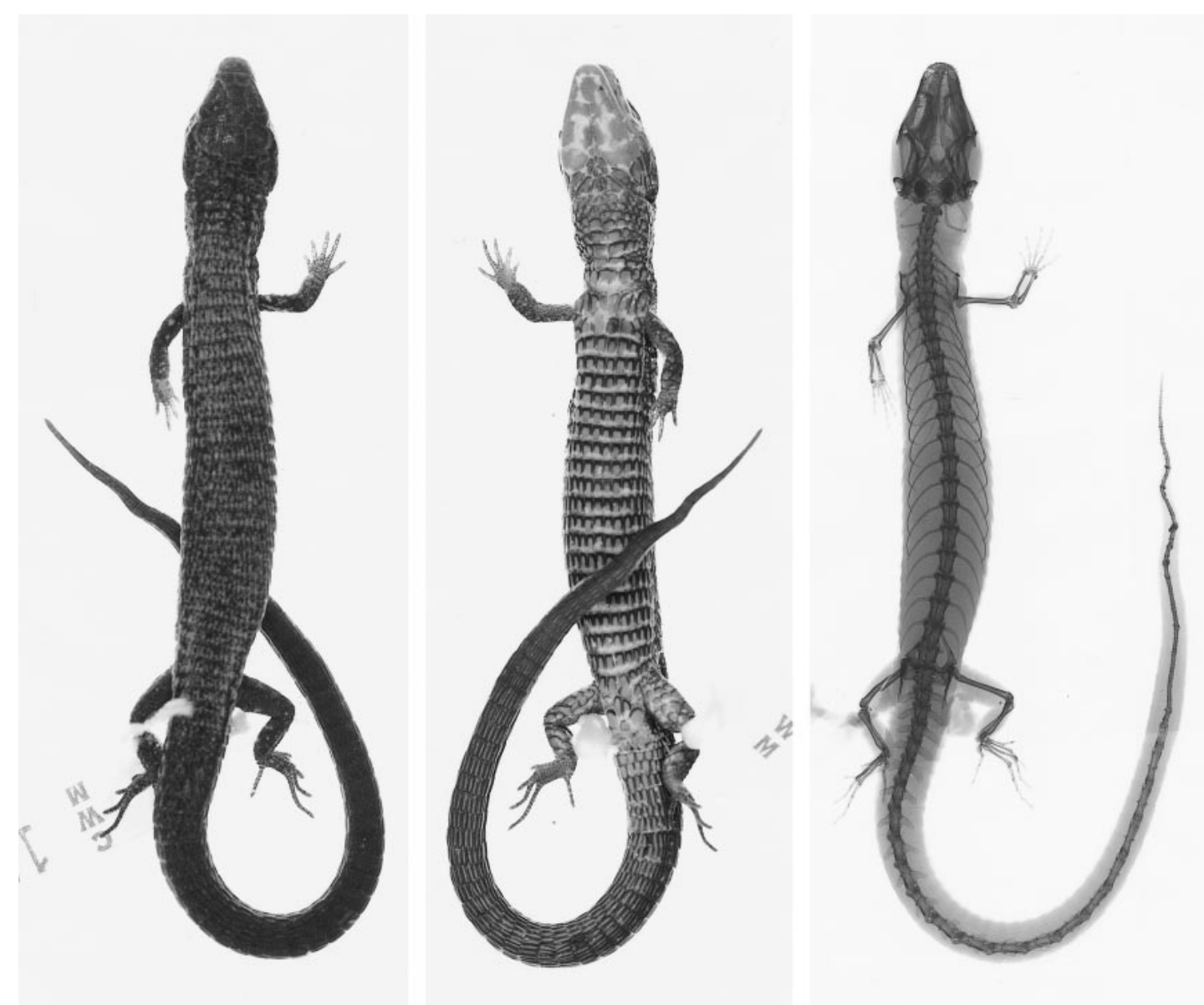

Fig. 32. Adercosaurus vixadnexus, new species. Dorsal, ventral, and radiographic views of the preserved holotype $($ EBRG 31260), $\times 1.6$. Approximately the distal third of the tail is regenerated, as shown by the cartilaginous rod in the radiograph, although there is no clear external evidence of this.

dation between lateral and ventral scales; median ventrals smooth, rectangular, gently rounded posteriorly, subimbricate, forming both transverse and longitudinal rows. Preanal scales in two rows. Femoral pores and preanal pores on same line. Limbs pentadactyl, all digits clawed; subdigital lamellae divided; base of pollex with enlarged thenar scales having produced median keels. Caudal scales similar to body scales, in uninterrupted annuli, no paramedian series of supracaudals along a vertebral suture.

In having oblique plicae on the anterior as well as the posterior part of the tongue, $\mathrm{Ad}$ ercosaurus seems to stand apart from all other microteiids (including Arthrosaura) except Alopoglossus, Ecpleopus, Ptychoglossus, and
Riolama, but it stands with Ecpleopus and Riolama in having the lingual plicae interrupted by a midsection of scalelike papillae. Among these genera, Adercosaurus most closely resembles Arthrosaura and some Ptychoglossus in habitus and body scalation, but those two genera and Alopoglossus are distinctive in having the posterior margins of the parietals and interparietal forming a moreor-less straight line across the rear of the head (interparietal posteriorly projecting, forming a jagged or irregular line in Adercosaurus and Riolama, a gently rounded line in Ecpleopus). Ecpleopus differs from all in having hexagonal ventrals that do not form longitudinal rows, the ventrals being being arranged in transverse rows only. 
The endemic tepui genus Riolama differs from Adercosaurus in lacking a claw on the first finger, ${ }^{22}$ in having the subdigital lamellae mostly undivided, and in having smooth lateral scales that are smaller than the keeled dorsals.

The primarily Andean genus Anadia also reaches the tepuis, but it differs most conspicuously from other tepui microteiids in having a tight covering of nonmucronate (and usually smooth) dorsal scales that are juxtaposed or only subimbricate, as well in having a very long tail and a relatively attenuated, flat-topped snout that give it a distinctive aspect. Anadia evidently differs from Adercosaurus in hemipenial morphology (comblike rows of spinules in Anadia) and in the dorsal surface of the tongue (scalelike papillae anteriorly), but summary data for Anadia have not been published. Anadia, however, has been characterized as having (in 9 species) 6-10 swollen infralingual plicae (Harris, 1985), which differs from the three thin (nonswollen) infralingual plicae in Adercosaurus.

See below for additional comparisons (under Diagnosis and Remarks in species account).

Distribution: Known only from $1700 \mathrm{~m}$ on the Yutajé-Corocoro massif.

\section{Adercosaurus vixadnexus, new species}

Figures 31-36, 37 (top), 38, 39

Holotype: EBRG 3126 (field no. CWM 19809), an adult male from wet gallery forest on Cerro Yutajé, $1700 \mathrm{~m}\left(5^{\circ} 46^{\prime} \mathrm{N}, 66^{\circ} 08^{\prime} \mathrm{W}\right)$, Amazonas, Venezuela; collected February 25, 1995, AMNH-TERRAMAR Expedition. See locality 1 on map (fig. 1).

ETYMOLOGY: The species name is compounded from the Latin adverb vix (barely, hardly) + the passive past participle adnexus (tied together or joined, connected), calling

\footnotetext{
${ }^{22}$ Both Boulenger (1900) and Uzzell (1973: 54) stated that the holotype of Prionodactylus leucostictus-type species of Riolama Uzzell - has all digits clawed. But E. N. Arnold kindly examined the specimen at our request and assured us that the first finger is clawless, as in a specimen of Riolama from Cerro Duida (Myers and Donnelly, 1996: 22n). D. M. Harris (personal commun.) and R. W. McDiarmid (personal commun.), who have studied the holotype and other specimens, consider a clawless first finger to be diagnostic of Riolama.
}

attention to the possibly diagnostic point contact of the frontoparietal plates (fig. 34).

Diagnosis: The generic definition and diagnosis are thought to differentiate Adercosaurus vixadnexus from all other teiids. The point contact of the frontoparietals, if a consistent character, will alone separate $A$. vixadnexus from other teiids with few exceptions (see Remarks).

On the Guayanan tepuis, A. vixadnexus is most likely to be confused with the upland species of Arthrosaura, which have brown dorsa, similar body scalation, and sometimes dark ventral markings; also the third pair of genials are in lateral contact with the infralabials in both genera. However, as indicated above, Arthrosaura is immediately distinguished from other tepui microteiids in having the posterior margins of the parietals and interparietal forming a nearly straight line across the rear of the head, and Adercosaurus further differs significantly from Arthrosaura in tongue morphology and in having a linear series of curved, nude tissue ridges across the asulcate side of the hemipenis (rather than oblique folds with comblike rows of mineralized spinules).

The general appearance of the black-outlined, white-centered ventral markings of the holotype of Adercosaurus vixadnexus, including the mottled throat (figs. 31, 32, 35), probably is distinctive among teiids generally and is quite different from the several tepui lizards with dark ventral surfaces. Arthrosaura tyleri tends to have dark-centered ventral scales and lacks the throat mottling (Donnelly et al., 1992: fig. 4). Male Prionodactylus goeleti may have extensive black on the throat and venter (Myers and Donnelly, 1996: fig. 18), and the male holotype of $P$. nigroventris was "shiny jet black" over all ventral surfaces (Gorzula and Señaris, 1999: 137), but these Prionodactylus differ noticeably from Adercosaurus in having small lateral scales and a vivid pale labial line extending posteriorly to the shoulder. The tepui endemic Riolama leucosticta differs in being overall black with small, vividly defined yellow spots and yellow mandibular stripes (Gorzula and Señaris, 1999: color photo 91), and Riolama (including unnamed species) also is immediately distinguished from Adercosaurus by lacking a claw on the first finger. 


\section{DESCRIPTION OF HOLOTYPE}

The undissected male holotype is the only known specimen. It is adult judged by the well-developed hemipenes. Snout-vent length $55 \mathrm{~mm}$; tail length $79 \mathrm{~mm}$ (regenerated); head length (obliquely from tip of snout to edge of ear) $10.6 \mathrm{~mm}$; greatest head width $7.7 \mathrm{~mm}$; greatest head depth $5.5 \mathrm{~mm}$; snout-axilla length $20.5 \mathrm{~mm}$; length of neck (posterior edge of ear to forearm) $8 \mathrm{~mm}$; trunk length (axilla-groin) $28 \mathrm{~mm}$; length of forelimb and of hindlimb (from axilla or groin to tip of longest digit) 11 and $15 \mathrm{~mm}$, respectively.

Head length $19 \%$ of SVL, 1.4 times longer than wide, and 1.4 times wider than high; head wider than neck. Neck long, $75 \%$ of head length, $29 \%$ of trunk length. Snout-axilla length $73 \%$ of trunk length, $37 \%$ of SVL. Body wider than deep. Tail externally appears to be original, but a radiograph (fig. 32) shows that distal third is regenerated (i.e., caudal vertebrae replaced by cartilaginous rod); regenerated tail 1.5 times SVL; tail nearly cylindrical, with barely perceptible lateral compression and slight ventral flattening. Limbs pentadactyl, all digits clawed (fourth digit lost from left hand). Forelimbs $21 \%$ of SVL, $39 \%$ of trunk length; hind legs $28 \%$ of SVL, $54 \%$ of trunk; adpressed limbs not overlapping, widely separated by five or six lateral scales.

Tongue (fig. 33) lanceolate, anterior half gray. Most of anterior half behind fork with oblique, anteriorly converging plicae, which extend around onto ventrolateral sides of tongue as distinct folds. Posteriorly, these elongate plicae start to become subdivided into shorter sections before they are replaced by a zone of scalelike papillae, which occupy the midsection of the tongue in an area overlapping the pigmented anterior and unpigmented posterior halves. Behind the scalelike papillae, the mostly unpigmented posterior half of the tongue again bears distinct, anteriorly converging plicae in the shape of chevrons; the proximal half dozen or so of the posterior plicae are emphasized by gray pigmentation along their free edges. Raised midventral side of tongue with a median groove, which continues anteriorly through three pairs of thin (nonswollen), oblique, anteriorly

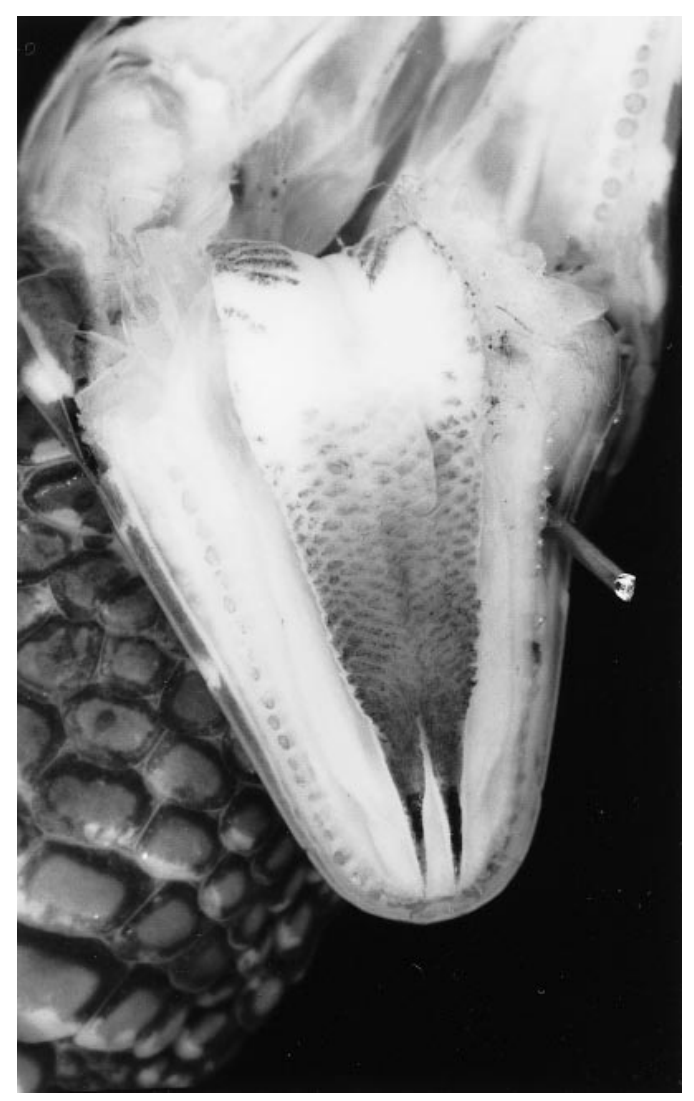

Fig. 33. Tongue of Adercosaurus vixadnexus, new species (holotype).

converging (chevronlike) infralingual plicae immediately behind fork; first pair of infralingual plicae slightly larger than second pair, third pair barely indicated. ${ }^{23}$

Anterior maxillary and dentary teeth nearly conical, slightly recurved; posterior maxillary and dentary teeth primarily bicuspid, with a rare tricuspid tooth; small pterygoid teeth present. ${ }^{24}$ Phalangeal formula of hands 2-3-4-5-3, of feet 2-3-4-5-4.

${ }^{23}$ The appearance of the infralingual plicae is similar to the condition illustrated for Ptychoglossus by Harris (1985: 562, fig. 2b), except that the apices of the anteriorly converging plicae are pointed in Adercosaurus, not slightly rounded.

${ }^{24}$ Tiny teeth on the pterygoid could be seen under magnification after the lower jaw was widely reflected (for the purpose of photographing the tongue). However, the pterygoid teeth are not discernible by magnification of a radiograph of this specimen, which lends support to Harris' (1994: 230) suggestion that pterygoid teeth in some small teiids have been overlooked by investigators who relied on radiographs. 

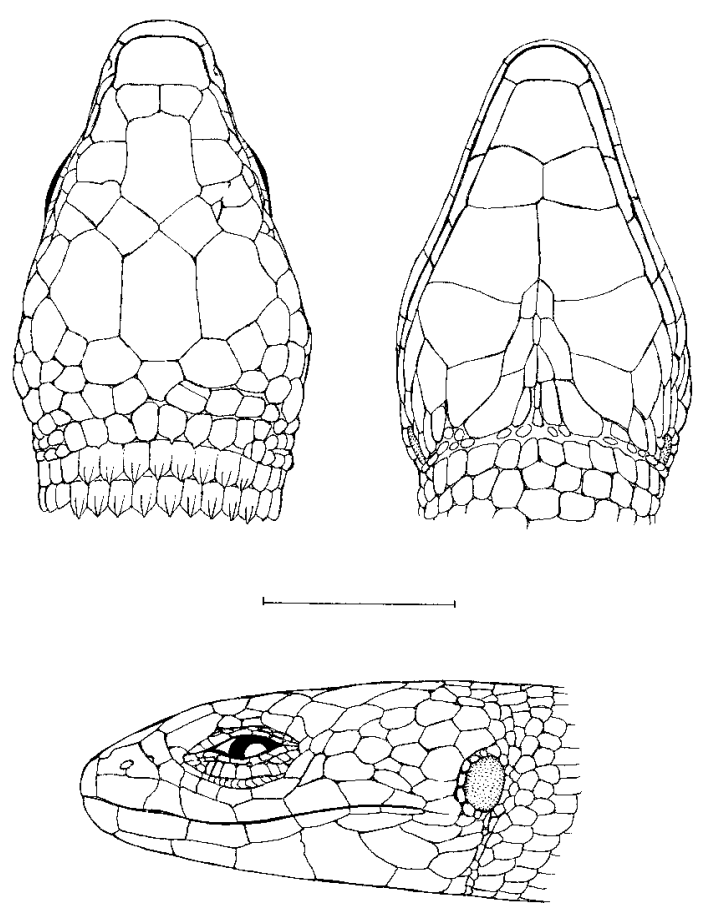

Fig. 34. Adercosaurus vixadnexus, new species. Dorsal, ventral, and lateral views of head of holotype $\left(\right.$ EBRG $\left.3126{ }^{\star}\right)$. Scale line $=5 \mathrm{~mm}$.

Head scales (fig. 34) smooth, with numerous minute scale organs (pits) especially concentrated on anterior head plates (dorsal, lateral, and ventral), becoming posteriorly situated mainly on margins of head plates and nape scales. Similar minute pits also sparsely distributed on edges of dorsal scales.

Snout rounded. Rostral plate much wider than deep, laterally in contact with nasal and first supralabial, dorsally in contact with frontonasal. Anterior and posterior edges of frontonasal nearly straight. Paired prefrontals medially in broad contact. Frontal slightly hexagonal, with weak anterior apex and pronounced posterior one, longer than wide. Frontoparietals two, rhomboidal, barely in median contact. Supraoculars four, in contact with superciliary series; posterior two supraoculars on right aberrantly subdivided (fig. 34). Interparietal longer than wide, heptagonal, with anterior apex and short, straight posterior edge; lateral edges of interparietal not quite parallel, slightly diverging posteriorly. Parietals longer than wide, but shorter than interparietal, which extends farther cau- dad-posterior margins of parietals and interparietals forming a jagged line across rear of head. Occipitals (postparietals) three, followed by a medially interrupted transverse row of four smaller postoccipitals, which in size are subequal with dorsal neck scales.

Nostril situated below center of nasal, which is undivided albeit with a very faint, thin groove below nostril. Loreal anteriorly inclined, higher than wide, dorsally in contact with frontonasal and first supraocular at their narrow suture, ventrally well separated from supralabials by frenocular. Preocular scales two, very small, between first superciliary and first subocular. Superciliaries five, with an azygous scale on both sides lying above the suture between small second and third superciliaries, and below suture between second and third supraoculars; first superciliary long and wide. Suboculars four, moderately large, behind frenocular, none greatly elongate. Postoculars two, upper smallest, between superciliary and subocular series. Supralabials seven on left side, six on right, ultimate plate smallest on each side.

Upper eyelid with eight or nine ciliaries, none exceptionally enlarged. Ocular recess with one row of small, flat scales separating all but first few and last few ciliaries from superciliaries. Lower eyelid with nine ciliaries of subequal size. Lower eyelid scaled, with a large but not well-defined opaque median window (palpebral disc) with approximately six vertical divisions. Palpebral disc mostly in contact with lower eyelid ciliaries, with only a few minute scales intervening.

Temporal region between postoculars and ear with approximately 21 irregularly shaped, juxtaposed smooth scales. Ear opening vertically oval, edged around with small, smooth scales, those on anterior edge swollen; a row of small flat scales around inner rim of opening. Auditory meatus shallow, tympanum lightly pigmented.

Posterior margin of mental nearly straight. Postmental large, slightly pentagonal, wider than long, laterally in contact only with elongated first infralabial on each side. Genials in three pairs, all in contact with infralabials; first two pairs in broad median contact; third pair of genials widely separated by intervening pregular and other scales. A pair of sideby-side, moderate-size postgenials (or pre- 

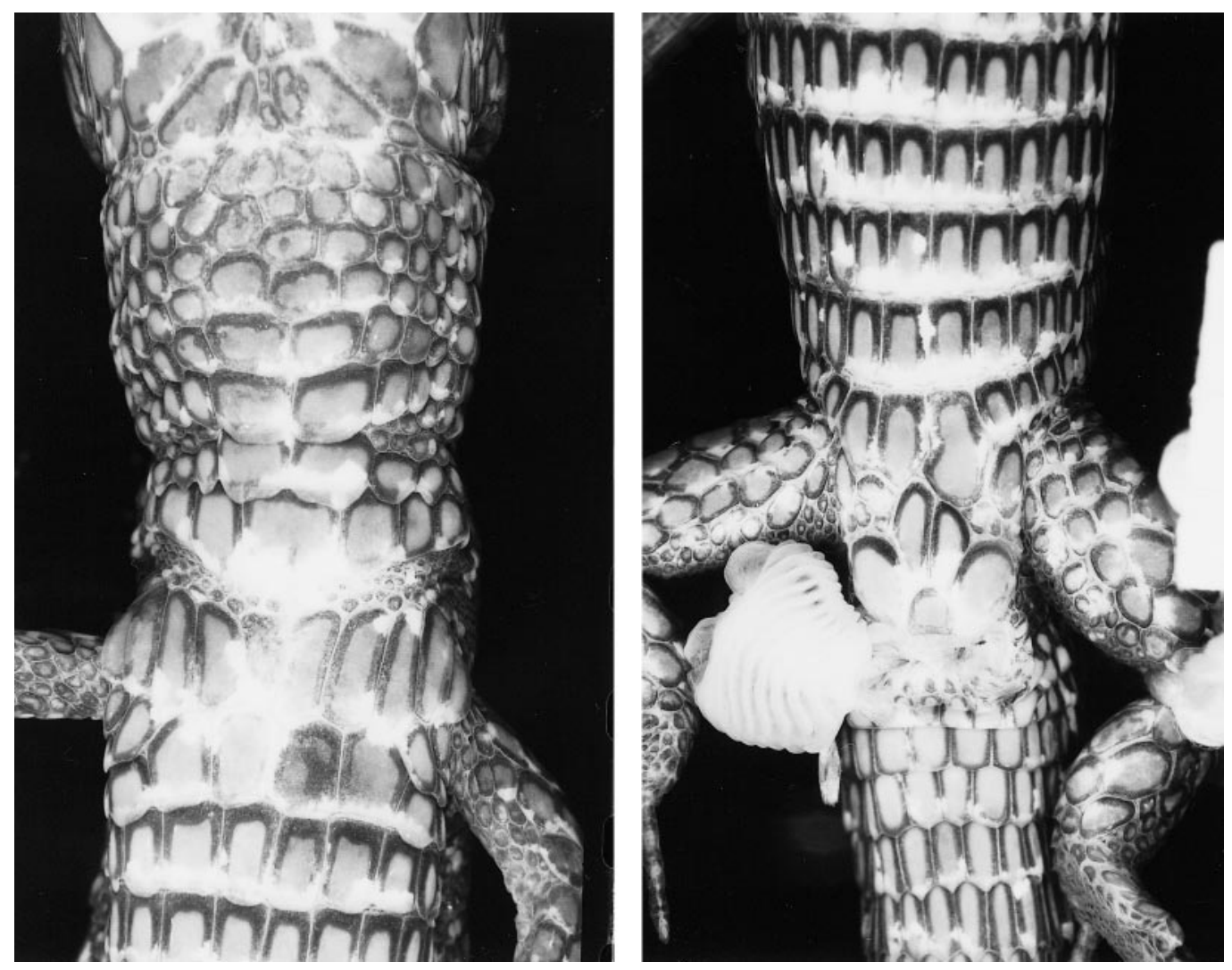

Fig. 35. Adercosaurus vixadnexus, new species (holotype). Details of gular-pectoral (left) and subpelvic (right) regions.

gulars) in posterior contact with each member of the third pair of genials; lateral member of each pair of postgenials separated from infralabials by an elongated sublabial. The third pair of genials and the two pairs of postgenials widely separated by wedge of three pairs of pregulars, first pair in contact, second and third pairs separated by irregular smaller scales.

A narrow but distinct gular crease crossing anterior edge of throat from ear to ear, evident in both lateral and ventral view; gular crease bearing a line of tiny scales contiguous laterally but becoming widely separated ventrally. Seven transverse rows of gulars between gular crease and collar scales; first several gular rows somewhat irregular (third row incomplete); two middle scales in last three rows forming double row of enlarged, paramedian gulars, each succeeding pair larger than the preceding (fig. 35). Gulars im- bricate. Well-defined guttural fold, with tiny scales, not crossing throat, ending ventrolaterally on each side at suture between second and third double rows of enlarged gulars. Collar row with seven scales, the median scale about as wide as long and much larger than the longer-than-wide lateral collar scales. Collar fold very evident, with 2-3 rows of tiny scales broken by median gap. Conspicuousness of anterior gular crease, incomplete guttural fold, and collar fold not due to distention of neck with preservativeall evident in life (as determined by enlargement of transparency used for fig. 31, bottom).

Sides of neck with covering of mediumsized, oval or rounded, smooth juxtaposed scales, arranged in about eight oblique rows, which do not (or only weakly) form annuli with nape and gular scales. Last two rows of neck scales anteriorly delimited by 1-2 rows 


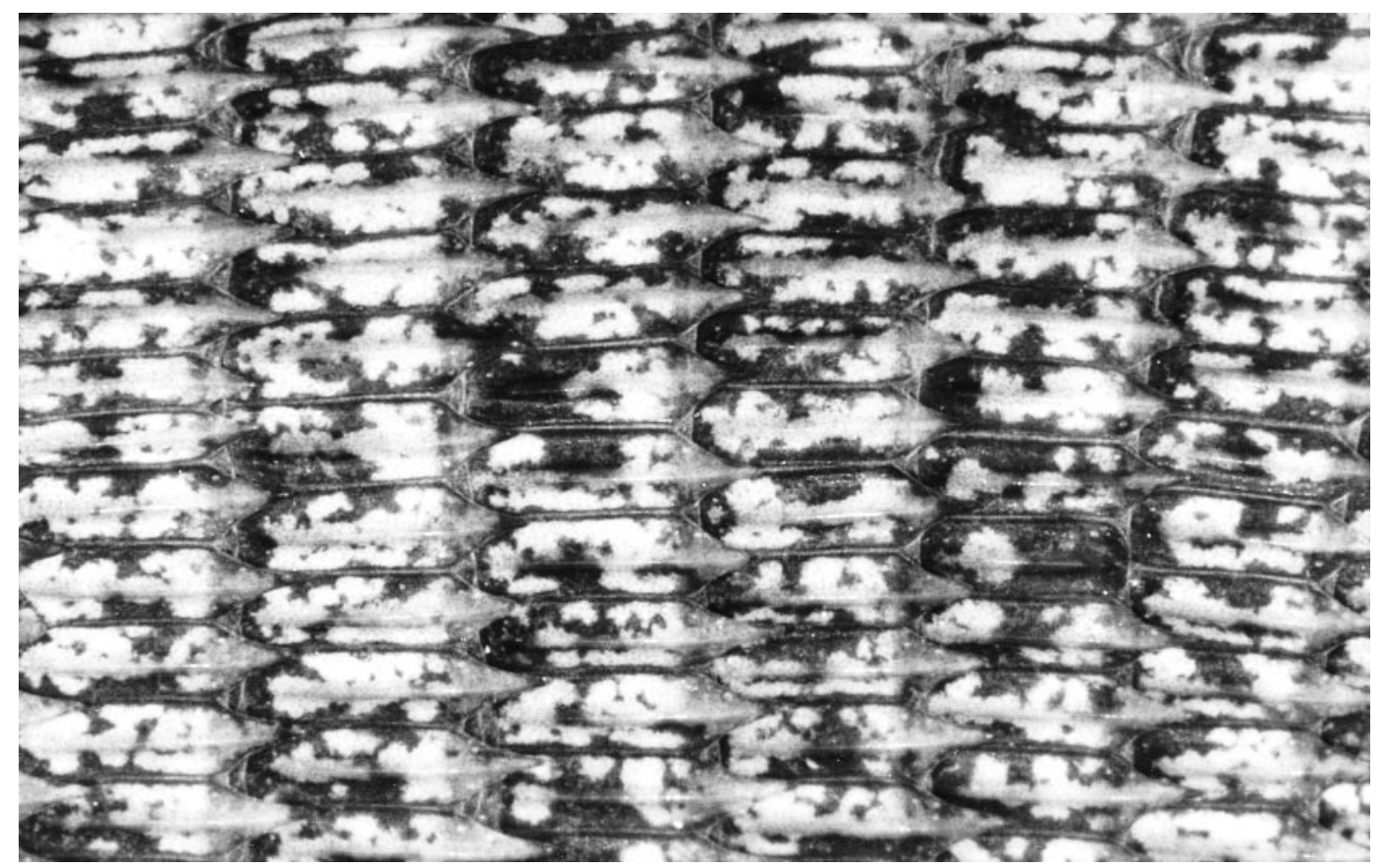

Fig. 36. Adercosaurus vixadnexus, new species (holotype). Dorsal midbody scales (anterior is left), $\times 18$. An odd, nonmucronate rectangular scale is visible in the lower right quadrant.

of tiny scales in guttural fold and posteriorly delimited by tiny scales anterior to arm. Area of roughly $6-8$ rows of tiny scales in axilla continuing as semicircle up over arm and then ventrad, with a few rows then confluent with tiny scales in collar fold.

Dorsal and lateral scales (fig. 36) elongated, parallel-sided, hexagonal, ${ }^{25}$ keeled and strongly mucronate-keels extending posteriorly as elongated, acute points. Scale keels sharpest dorsally, becoming sharpest posteriorly on body, losing definition on nape and sides of body, where narrow median keels are replaced by wider, smooth-top elevated thickenings. Dorsals and laterals otherwise homogeneous, in uninterrupted transverse rows; no lateral fold or line of small scales. Dorsals in 36 transverse rows between inter-

\footnotetext{
${ }^{25}$ Although misleading, "hexagonal" is a venerable and still useful descriptor for the body scales of some microteiids. Hexagonal scales are parallel-sided, elongated pentagonal scales that are arranged in transverse but not in longitudinal rows. The free pointed tips of laterally adjacent scales fall into sutures between scales in the next transverse row, causing each single scale to appear six-sided.
}

parietal and posterior edge of thigh held at right angle to body.

Caudal scales (fig. 37, top) similar to body scales, in uninterrupted annuli (no intervening small scales); supracaudals not forming paramedian series along a vertebral suture; supracaudals strongly keeled to end of tail, keels becoming broader and blunter on lateral scales and disappearing ventrally.

Ventral scales forming both transverse and weak longitudinal rows. Ventrals in 21 transverse rows between collar and pair of anterior preanals, with some irregularity in size of scales in first and last rows. Ventrals in about eight longitudinal rows of smooth scales at midbody - a subjective count inasmuch as the mucronate lateral scales grade imperceptibly into ventrals, both in shape and in a gradual shift to longitudinal rows; lateralmost one or two scales bluntly pointed; scales in median four or five ventral rows nearly rectangular, but with their free edges slightly rounded and barely overlapping the bases of scales following (i.e., weakly imbricate).

Marginal preanal scales three, outer two 

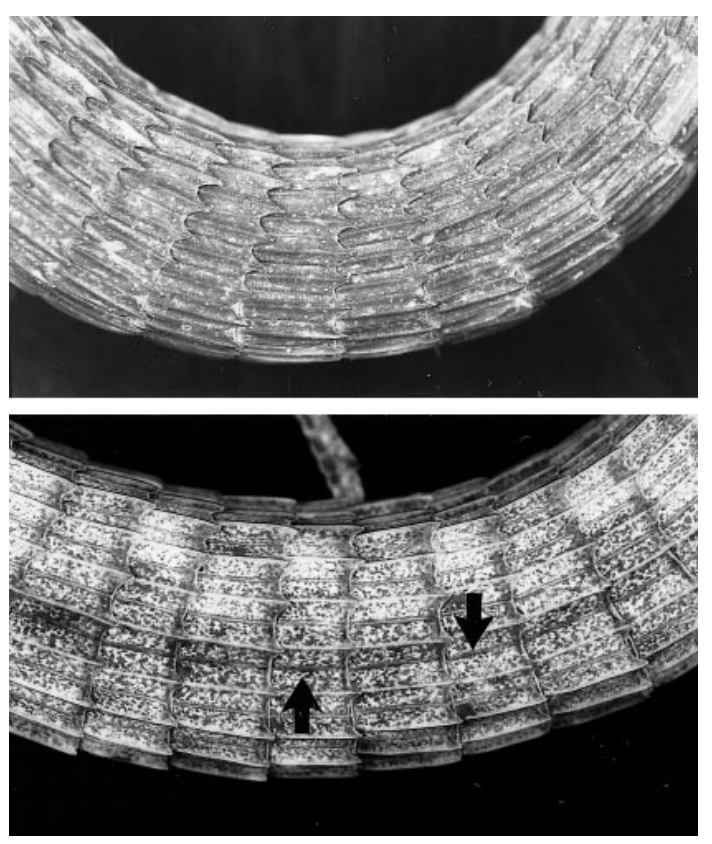

Fig. 37. Caudal scutellation in dorsal view (anterior is left). Top: Adercosaurus vixadnexus, new species (holotype), showing scales arranged in transverse rows only; there is no paramedian series along a vertebral suture. Bottom: Ptychoglossus plicatus (AMNH 114307 ðै, Panama), showing supracaudals arranged in both transverse and longitudinal rows; arrows indicate vertebral suture separating paramedian series.

more than twice the size of median one; pair of elongate preanal scales in posterior contact with the small, median marginal scale (fig. 35 ). Femoral pores $2 / 2$ on posteroventral surface of thigh, preanal pores $2 / 2$ in same line as femoral pores; each femoral and preanal pore surrounded by 3-5 irregularly shaped small scales.

Scales on dorsal surface of arm, hand, and ventral side of forearm large (wider than dorsal body scales), imbricate to juxtaposed, smooth, rhomboidal or irregularly shaped; scales on underside of upper arm small, smooth, slightly swollen, juxtaposed. Scales on anteroventral surface of thigh and most of lower leg large, mostly smooth (a few keels on posterior scales atop thigh); posterodorsal and posterior surface of thigh pebbled with smooth, swollen granules. Supradigital scales glossy, squarish or longer than wide, distal scale proximal to ungual scale especially

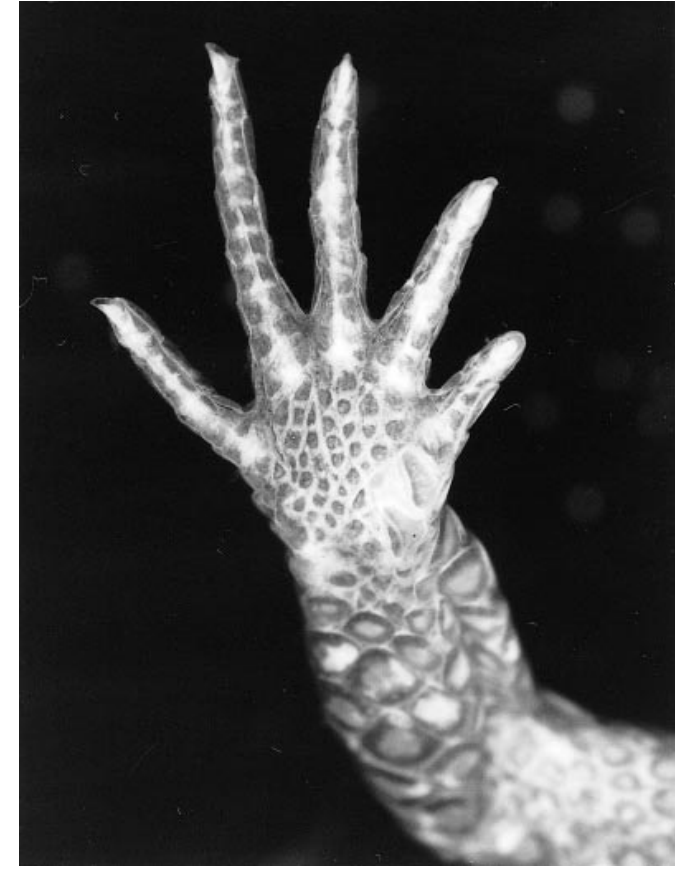

Fig. 38. Adercosaurus vixadnexus, new species. Palmar view of right hand (holotype).

elongated. Palms and soles covered with small, rounded juxtaposed scales that are not thickened or rounded. Two enlarged thenar scales on inner margin of palm below pollex (fig. 38), each with produced inner edge; a similar but smaller pair of enlarged keeled scales below first toe. Subdigital lamellae divided (each half tends to be inclined up toward the middle, forming median subdigital keel between the paired scales, but this may be an artifact of preservation or desiccation).

Subdigital lamellae as follow (Roman numerals indicate digits, Arabic numbers indicate pairs of lamellae on left/right feet): forefoot, I 4/4 II 6/6 III 8/8 IV-19 V 6/6; hind foot, I 4/3 II 6/7 III 10/10 IV 14/14 V 8/8. (A few of these counts are approximations owing to a combination of desiccation and variation in scales at bases of digits; the divided lower ungual sheath scale is omitted from the counts.)

COLORATION: In life (fig. 31), the dorsum was brown, with indication of a paler brown dorsolateral line; the sides were black with whitish flecks; the ventral surfaces were strikingly patterned in black and white. 
Close inspection of the preserved specimen (fig. 32) shows the brown dorsal scales to be finely mottled with darker brown. The paler tan dorsolateral line extends posteriorly from the eye, across the upper temporal region, and well above the ear to the anterior body. The dorsolateral line reappears at the end of the body, extending above the hind legs and onto the base of the tail for a distance of 7-8 caudal annuli. The sides of the body are mostly black, with irregular small whitish and tan spots. The lips are dark except for a few small white areas, which are situated mainly along the edges of the mouth at sutures between the labial scales. The underside of the head is mottled black and white, turning darker on the throat. The basal and lateral edges of the ventral and most subcaudal scales are black, offsetting grayish white centers.

HEMIPENIS: The genitalia of the holotype were field everted, and the left organ was subsequently removed and inflated with red petroleum jelly (fig. 39). This hemipenis is 5 $\mathrm{mm}$ long, with a greatest width of nearly 4 $\mathrm{mm}$. The organ is bilobed, each of the short symmetrical divisions terminating in a flattened, trilobed apical disc of thick tissue. The two discs tilt slightly mediad toward one another, with the medial lobe of each disc being deflected distad, resulting in paired projections between the outer flat parts of the discs.

The sulcus spermaticus is a broad, indefinite channel, from which two narrow, ill-defined groves form below the crotch (without visible bifurcation); these weak, distal sulcate branches diverge with centrolineal orientation, each branch extending into the gap between the medial and sulcate-side lobes of the apical disc. The thickened tissue comprising the apical discs is proximally continuous with the broad medial band of tissue that bears the sulcus spermaticus (fig. 39).

There is a conspicuous series of 11 or 12 curved, nude tissue ridges across the asulcate surface, encircling the side of the organ and terminating laterally on the sulcate face. The distal ridge at the base of a hemipenial lobe is small and ill-defined; the continuity of the basal seven ridges is broken on the side of the organ by a nude area extending up from the base. No mineralized spines, spinules, or hooklike papillae are evident at high mag- nification, nor were such structures evident after the organ had been immersed for 24 hours in a solution of Alizarin Red.

\section{REMARKS}

The unique specimen of Adercosaurus vixadnexus was found near camp by our colleague Paul Sweet, at about 8 a.m. on a sunny morning, after a night of local flooding (which sometimes displaces small inhabitants of the ground litter). It was on soggy ground at the edge of wet mossy gallery forest. We assumed in the field that the specimen was an Arthrosaura, but, in preparing this paper, we found that it fits neither there nor in such extralimital genera as the physiognomically similar Ptychoglossus (see Harris, 1994). Adercosaurus thus joins Riolama (Uzzell, 1973) as a second genus of microteiids that seems to be endemic to the Venezuelan tepuis. Their relationships remain to be determined.

Our colleague Dennis Harris (personal commun.) called our attention to the possibly diagnostic point contact of the frontoparietal plates. Harris noted that the form of the frontoparietals is very conservative in "group II teiids", except for obvious (bilaterally assymetrical) anomalies or when there are radically different head scales (as in Neusticurus, Echinosaura, Teuchocercus). Otherwise, the frontoparietals, unless absent (as in Gymnophthalmus), characteristically have a broad median suture. Interestingly, one exception is Arthrosaura reticulata, in which the medial suture varies "from short to relatively wide" (Avila-Pires, 1995: 337, fig. 111).

A resemblance in tongue morphology between Adercosaurus and Riolama is of interest, although variation in lingual surface morphology is not well accounted for. According to Uzzell (1973: 52), the holotype of Riolama leucosticta has a tongue ornamentation of chevron-shaped plicae on the anterior and posterior thirds, separated by scalelike papillae on the middle third-similar to Adercosaurus as described herein. However, at least in some Riolama spp. (e.g., AMNH 141343, Cerro Duida, and AMNH 132118132119, Cerro de la Neblina) the tongue seems almost entirely plicate, with, at most, a few short, scalelike subdivisions of the pli- 

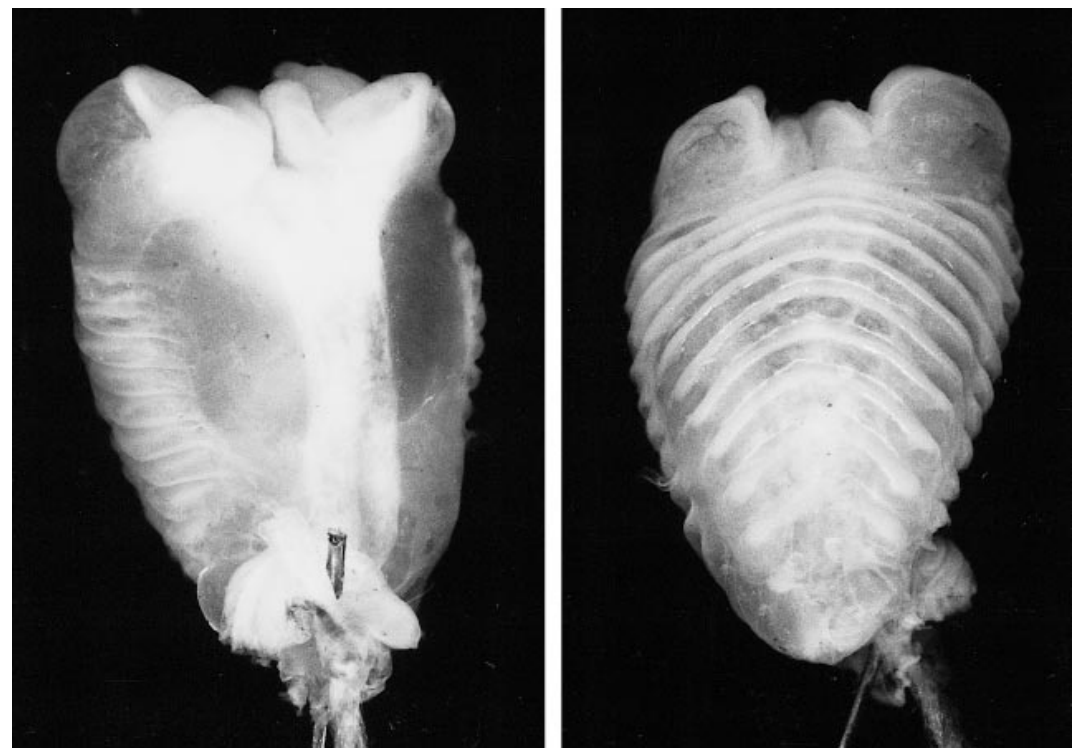

Fig. 39. Hemipenis of Adercosaurus vixadnexus, new species. Everted left organ of holotype, in sulcate (left) and asulcate view, $\times 12$.

cae occurring on the lateral edges of the tongue at its midsection. A Brazilian microteiid, Ecpleopus gaudichaudi, has a variable tongue morphology according to Uzzell (1969: 5), who stated that "the middle and sometimes the posterior part" are covered with scalelike papillae, but that the usual plicae at the anterior tip were lacking in one specimen. Another specimen of E. gaudichaudi (AMNH 131869) not then available to Uzzell clearly has anterior and posterior lingual plicae interrupted by a midsection of scalelike papillae.

Macroteiids and nearly all microteiids are characterized by scalelike papillae over most of the tongue. Often it is not convenient to examine the proximal part of the tongue without risk of damage to the specimen, but a combination of anterior scalelike papillae and posterior plicae is the common condition according to Ruibal (1952: 511), who stated that "Actually most teiids that have imbricate scale-like papillae on the tongue may have the posterior bifurcation covered with oblique plicae."

Heretofore, only Alopoglossus, Ecpleopus, Ptychoglossus, and Riolama seem to have been reported to have plicae also on the anterior part of the tongue (Uzzell, 1973: 54), with the fully plicate tongues of Alopoglossus and Ptychoglossus being "practically a unique feature" (Harris, 1994: 229). But the taxonomic distribution of anterior lingual plicae, as well as extent of intraspecific variation, is not known with certainty. This was brought home by casual examination of specimens of the long-tailed microteiid genus Pantodactylus. Specimens of Pantodactylus schreibersii (AMNH 32776, 144571) have, as expected, mostly scalelike papillae and posterior plicae, but a specimen of $P$. quadrilineatus (AMNH 131877, São Paulo) has anterior plicae that give way to scalelike papillae posteriorly (proximal part of tongue not examined).

Most of the morphological features commonly used to diagnose genera of Teiidae have been in use for over a century (see Boulenger, 1885: 330 et seq.). However, in a series of important papers in the 1960s and 1970s, Thomas Uzzell removed and stained the uneverted hemipenes of many microteiids (see especially Uzzell, 1973: 40-46). Uzzell showed that, in addition to various small spines, the hemipenes of many if not most microteiid genera have facing series of oblique or chevron-shaped folds or flounces that bear comblike rows of mineralized spi- 
nules, which are easily stained with Alizarin Red. The complex folds formed by the lobes at the tip of the uneverted organ were not amenable to study by dissection, and the spinule-bearing flounces on the body of organ were characterized as being in pockets. With more field-inflated hemipenes becoming available, the spinule-bearing flounces are seen to be superficial on the surface of the everted organ (e.g., Donnelly et al., 1992: fig. 3; Myers and Donnelly, 1996: fig. 20), and the everted apices take on recognizable shapes of systematic value (see especially Harris, 1994).

"Nude" hemipenes lacking mineralized spines or spinules, although uncommon among microteiids, are characteristic of $E c$ pleopus (Uzzell, 1969: fig. 8, uneverted) and Ptychoglossus, with the latter having "flounces of the form found in macroteiids and the closely related genus Alopoglossus, a primitive condition among microteiids" (Harris, 1994). Adercosaurus resembles Ptychoglossus and Alopoglossus in general hemipenial morphology. The similarity of the asulcate nude ridges or flounces can be seen by comparing photographs of the left everted hemipenes of Adercosaurus vixadnexus (fig. 39) and Ptychoglossus plicatus (Harris, 1994: fig. 17 [AMNH 114307]). Not visible in photographs are extremely minute bumps or microknobs, which are barely discernible on these two organs under the dissecting microscope; their structure is not resolvable at a magnification of $\times 50$. Possibly these are the "densely packed minute hook-like papillae" said by Harris (1994: 229, 231) to ornament the nude flounces of Ptychoglossus and Alopoglossus. If so, they are too easily overlooked to provide taxonomic content at this time. They probably represent the largest features in the epithelial landscape, which is best studied by scanning electron microscopy.

\section{Prionodactylus goeleti (Myers and Donnelly), new combination Figures 40, 41, 42 (top), 43 (part)}

Euspondylus goeleti Myers and Donnelly, 1996: 23-31, figs. 16-20. Holotype EBRG 3112 (field no. CWM 19639) from summit of Cerro Yaví, 2150 m, Amazonas, Venezuela; collected Feb- ruary 19-20, 1995, AMNH-TERrAMAR Expedition.

Prionodactylus phelpsorum (Lancini): Gorzula and Señaris, 1999: 139-141.

MATERIAL: AMNH 147038 (juv.), 147039 (egg shells), EBRG 3127 (egg shells), Cerro Yutajé, 1700 m, February 24-28, 1995.

An additional juvenile ("MHNLS 11387") was reported by Gorzula and Señaris (1999: 139) as being collected first on Cerro Corocoro on November 10, 1977, and secondly in the Serranía de Yutajé on March 22, 1988-presumably there actually are two specimens, although on page 141 they repeated the same number for "a juvenile male" from each locality.

\section{REMARKS}

The only lizard of this species obtained by us on Cerro Yutajé is an unsexed juvenile taken on rocks at the edge of a stream, at the $1700 \mathrm{~m}$ camp (fig. 40, left). A nesting site was found in a small mat $\left(0.09 \mathrm{~m}^{2}\right)$ of vegetation atop bare sandstone, in Tyleria-Stegolepis-Brocchinia scrub. Hatched eggshells of different-aged clutches were found on the rock underneath the small mat of vegetation and also in cavities within the mat. Two measurable shells were 10.6 and $11.0 \mathrm{~mm}$ long by 6.0 and $6.8 \mathrm{~mm}$ wide. Communal nest sites on Cerro Yaví were under rocks, mostly on layers of fibrous plant material or occasionally on fine sand (Myers and Donnelly, 1996: 30).

Our specimen from Yutajé is a juvenile of $25 \mathrm{~mm}$ SVL. In life, the pale middorsal stripe was beige and the dorsolateral and lateral lines were pale brown, with the lateral line being anteriorly confluent with a white labial line. The underside of the head was whitish and the venter pale green. Iris orange. Tongue sharply bicolor, the anterior third black.

The specimen compares favorably with three juveniles in the type series of Prionodactylus goeleti, collected several days earlier on neighboring Cerro Yaví, although a few differences can be found, especially the following: (1) the Yutajé specimen has relatively smaller scales in the midgular region (fig. 41). Although subtle, the difference could be seen with a jeweler's loupe when 


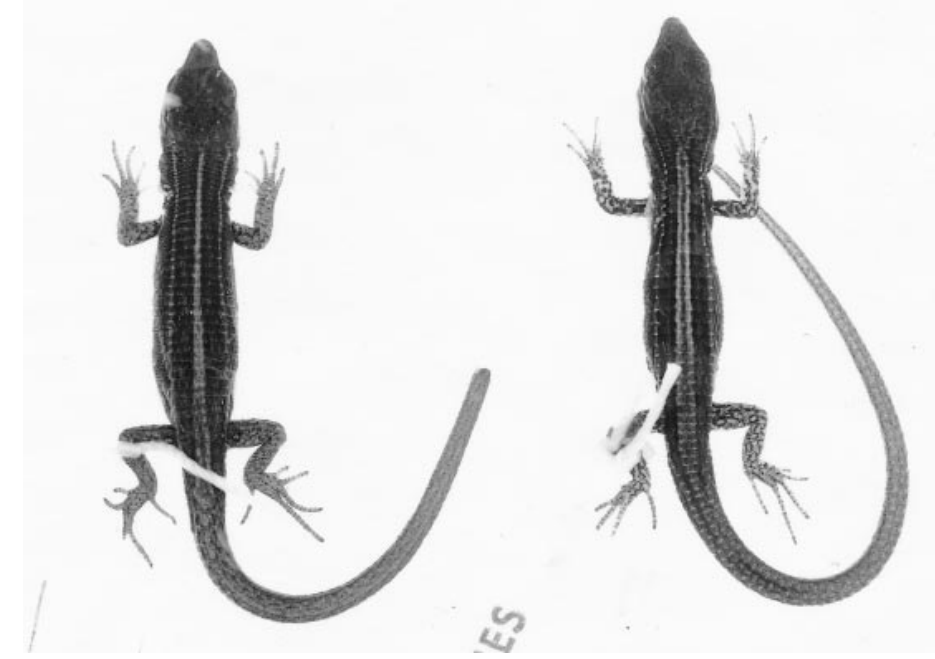

Fig. 40. Possible interpopulational difference in width of pale middorsal stripe in juvenile Prionodactylus goeleti (Myers and Donnelly), ×1.75. Left: Cerro Yutajé, a juvenile (AMNH 147038) $25 \mathrm{~mm}$ SVL. Right: Cerro Yaví, a juvenile paratopotype (AMNH 141331) 26 mm SVL. The middorsal stripe is narrower in juveniles than in adults, and its posterior widening becomes more noticable in adults (compare with fig. 43); see Taxonomic Notes.
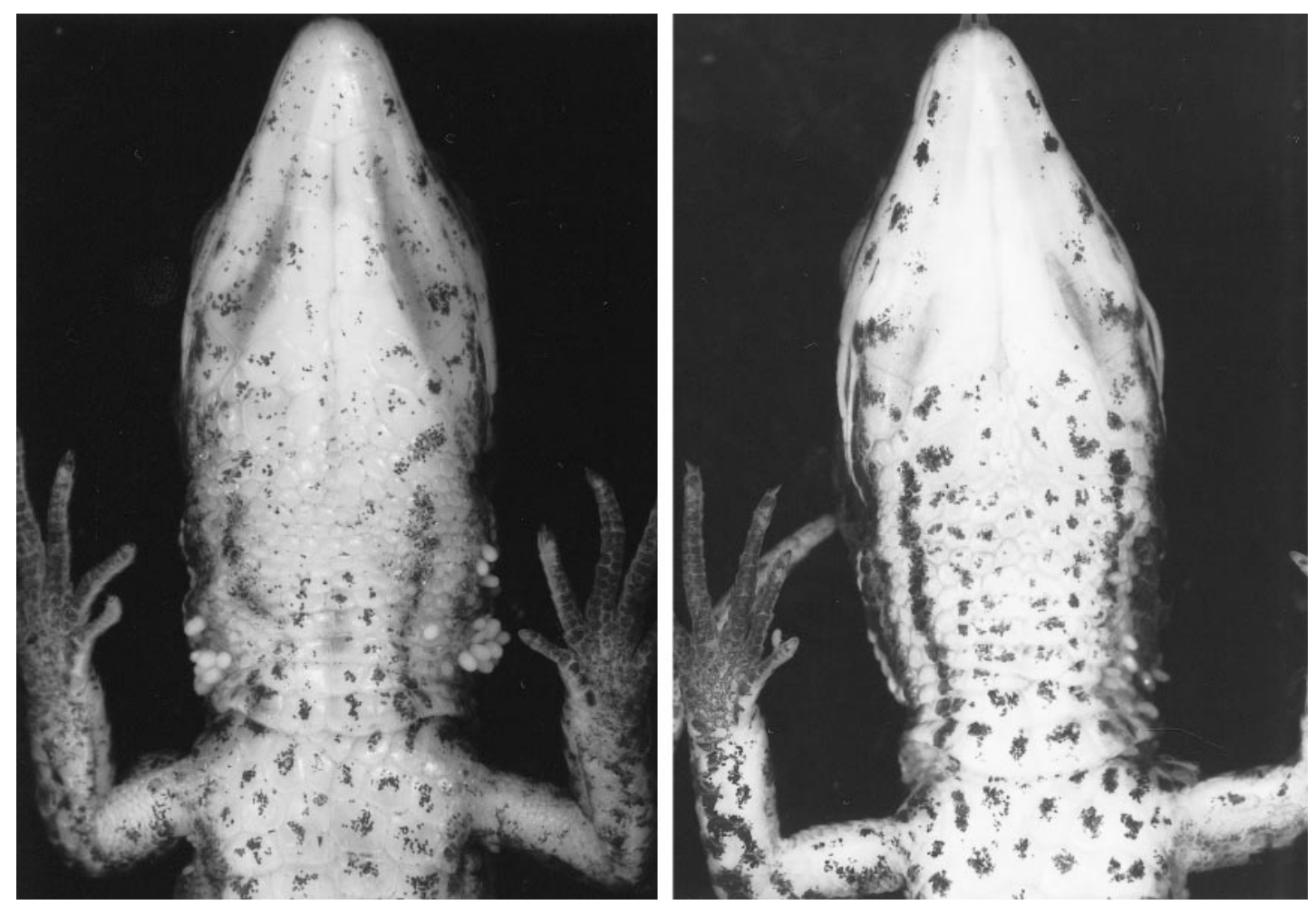

Fig. 41. Possible interpopulational difference in size of midgular scales in Prionodactylus goeleti (Myers and Donnelly). Left: Cerro Yutajé, a juvenile (AMNH 147038) 25 mm SVL. Right: Cerro Yaví, a juvenile paratopotype (AMNH 141331) 26 mm SVL. 

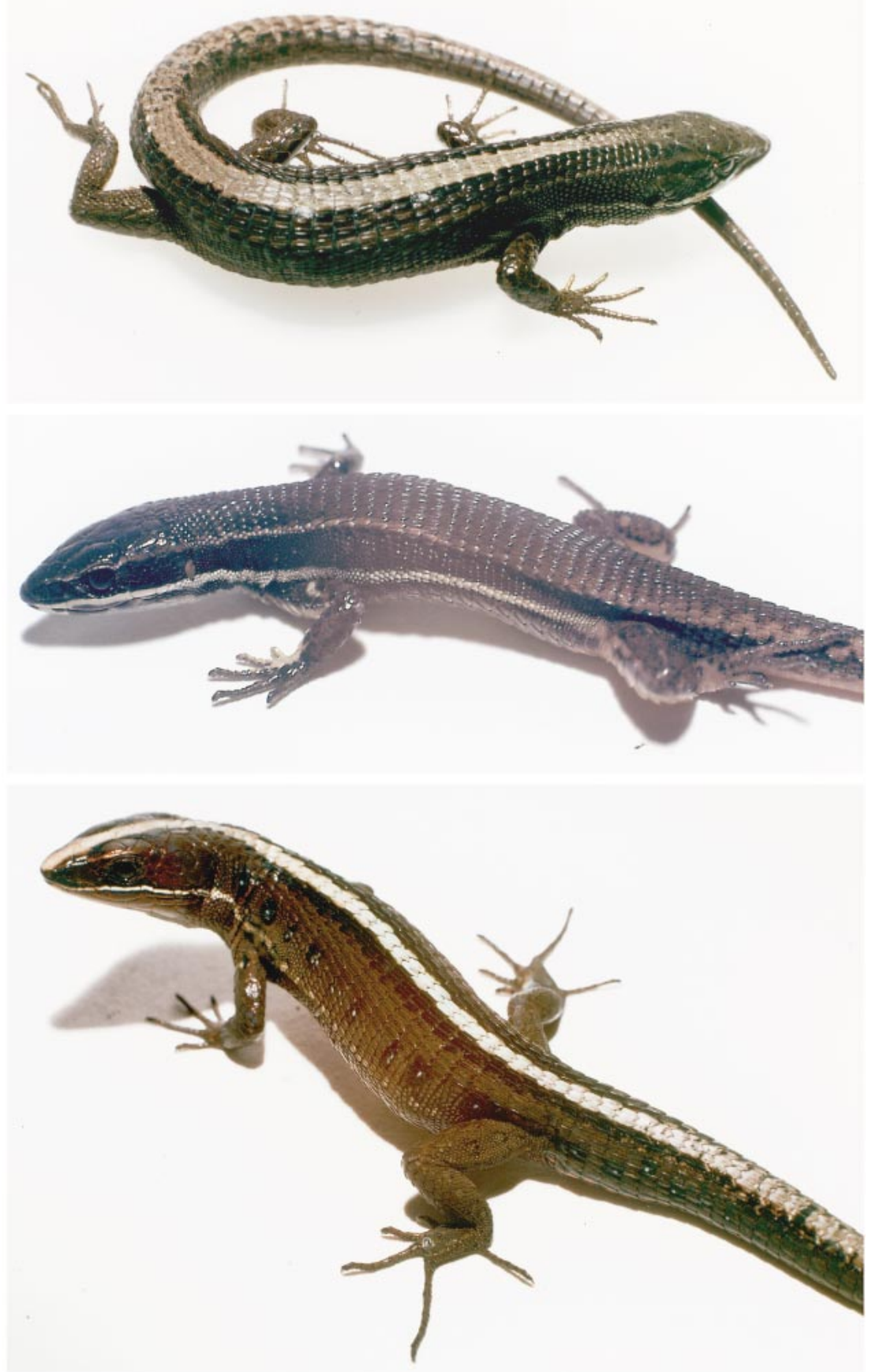

Fig. 42. Top: Prionodactylus goeleti (Myers and Donnelly), the adult male paratype (AMNH 141329, $50 \mathrm{~mm}$ SVL) from Cerro Yaví, Venezuela. Middle: The generic type species, Prionodactylus manicatus (O'Shaughnessy), an adult female (AMNH 113016, $44 \mathrm{~mm}$ SVL) from Cordillera Azul, eastern Peru. Bottom: Prionodactylus vertebralis (O’Shaughnessy), an adult male (AMNH 119368, 64 mm SVL) from Cerro Malí, on the Panamanian-Colombian border. 
the freshly preserved specimens were compared in the field. (2) The Yutajé specimen has a narrower middorsal stripe than do any of the three juveniles from Cerro Yaví. The last specimens are pictured in Myers and Donnelly (1996: fig. 19). One of the Yaví juveniles is shown here (fig. 40, right) in direct comparison with the Yutajé specimen, in which the median stripe is 1 scale wide between the arms, $1 \frac{1}{2}$ scales at midbody, and 3 scales wide above the inguinal region. Gorzula and Señaris (1999: 141) described the stripe of another juvenile from the Serranía de Yutajé as being similarly narrow (1 scale wide at nape, 2 scales at midbody, 3 scales above inguinal region). (See below for discussion of stripe width on Cerro Yaví.)

The samples are of course too small for reliable extrapolation. Nonetheless, the narrow median stripes in the aforementioned two juveniles from Cerro Yutajé suggest that the adults may also have narrower stripes than the adult lizards on Cerro Yaví. If so, Prionodactylus goeleti on the Yutajé-Corocoro massif is slightly differentiated from the population at the type locality.

\section{TAXONOMIC NOTES}

Generic Status: We follow Gorzula and Señaris (1999: 140) in their reassignment of Euspondylus phelpsorum (including E. goeleti) to Prionodactylus, although the generic situation remains unsatisfactory. Uzzell (1973) considered the type species of Euspondylus to be "essentially devoid of unusual external morphological" features, and he revived the younger name Prionodactylus from the synonymy of Euspondylus for species having "a double row of widened gular scales and keeled hexagonal scales". But these characters, even in combination, do not uniquely define Prionodactylus, and Euspondylus remains loosely defined. Paired median gulars seem to be a tendency in several microteiid lineages, and the character apparently is not strongly fixed in some Prionodactylus. Avila-Pires (1995: 453, 456, 470) noted that the gulars are occasionally irregular and not arranged in pairs in $P$. argulus and $P$. oshaughnessyi.

The hexagonal dorsal scales in Prionodactylus (and some other genera) appear distinc- tive when sharply keeled and strongly angular, but it is only a degree of difference from Euspondylus maculatus (type species), which has relatively wider (less elongate) rectangular scales. As in Priondactylus, however, the scales are disposed in transverse rows only, so that acquisition of points on the posterior scale margins would give the appearance of hexagonal scales. The presence or absence of keeling is not an absolute difference, inasmuch as some specimens of Peruvian Euspondylus maculatus have weakly keeled dorsals posteriorly on the trunk (keels absent in AMNH 1704 but present in AMNH 56268; posterior keeling was reported for a syntype by W. Peters, "1862" [1863]: 207).

Whether all the species of Prionodactylus form a monophyletic group that excludes Euspondylus maculatus is a problem for future revisionary work. Meanwhile, the generic reallocation of Venezuelan tepui species by Gorzula and Señaris has the practical advantage of associating them in the same group with the similar-appearing Andean Prionodactylus vertebralis (fig. 42, bottom).

Species ReCognition: Prionodactylus goeleti was described by Myers and Donnelly (1996: 23-31) on the basis of six specimens ( 3 adults, 3 juveniles) collected on Cerro Yaví in 1995. The species was recognized as being probably related to Prionodactylus phelpsorum (Lancini, 1968), which was described from an adult female taken in 1967 on Cerro Sarisariñama, ${ }^{26}$ some 240 km south-

\footnotetext{
${ }^{26}$ The type locality of Prionodactylus phelpsorum must be corrected as pointed out by Gorzula and Señaris (1999: 140), who called attention to a locality emendation by Steyermark and Brewer-Carías (1976: 180). Phelps (1977: 16 and map 1) provided further details of the geographic confusion that occurred on his pioneering 1967 expedition, when the lizard was collected. Owing to topographic complexity and misleading information from Maquiritare Indians, Phelps established a "Campamento Cerro Jaua" on what actually was the western side of the mesa of Cerro Sarisariñama.

Phelps (1977: 16-17) changed his specimen data from Cerro Jaua to Cumbre Occidental, Meseta de Sarisariñama, with coordinates estimated at $4^{\circ} 45^{\prime} \mathrm{N}, 64^{\circ} 26^{\prime} \mathrm{W}$. The helicopter-supported camp was occupied by Phelps' party for 10 days (March 20-29, 1967), with collecting carried out between 1900 and $2050 \mathrm{~m}$ above sea level The holotype of Prionodactylus phelpsorum was taken at $1917 \mathrm{~m}$ on March 29 (Lancini, 1968: 2).

The locality was shown by Phelps (map 1) as "Cam-
} 
east of Cerro Yaví. The main diagnostic difference was that goeleti "is distinguished by a posteriorly expanded middorsal stripe."

The three adult and three juvenile $P$. goeleti were separately described, with clear indication of ontogenetic change in relative width and posterior widening of the middorsal stripe: "Three juveniles are colored similar to the adults although the pale brown middorsal stripe is relatively narrower and its posterior widening is less pronounced in the juveniles than in adults" (Myers and Donnelly, 1996: 27). The point was made with facing-page photographs comparing all specimens in the type series of goeleti, and equivalent stripe widths (total scales covered) were given for adults and juveniles (p. 27), as summarized below:

\begin{tabular}{lcc} 
Stripe width & $\begin{array}{c}\text { Adults } \\
\text { (scales) }\end{array}$ & $\begin{array}{c}\text { Juveniles } \\
\text { (scales) }\end{array}$ \\
\hline Between arms & $2-3$ & $2^{1 / 2}$ \\
Midbody & $3 \frac{1}{2}-4$ & $3-4$ \\
Inguinal region & 5 & 4 \\
\hline
\end{tabular}

We reiterate the above variation because we evidently should have dwelled on its obvious taxonomic implications, namely that ontogenetic variation should not be confused with noncorrelated individual variation and that the dorsal stripe in phelpsorum (juveniles unknown) is best compared with the adult condition in goeleti; juvenile goeleti have narrower stripes (although they too show the diagnostic posterior widening). In allocating the name Euspondylus goeleti to the synonymy of Prionodactylus phelpsorum, Gorzula and Señaris apparently confused ontogenetic variation with the kind of extensive intraspecific variation that is not correlated with age, sex, or geography. This caused them to differently interpret Lancini's photograph of the phelpsorum holotype-an adult female containing two eggs.

Lancini (1968) does not mention whether or not the middorsal stripe is expanded posteriorly. However, [Lancini's] Figure 7 shows a[n]

$\leftarrow$

pamento Phelps-Steyermark, 1967, 2000 m", and a photograph (fig. 2) of the habitat at $2000 \mathrm{~m}$ also was given. A camp on Cerro Jaua was later established, as shown on the same map. oblique view of the dorsum of the holotype where it can be seen that the middorsal stripe is narrow anteriorly [and posteriorly] and widens to cover the dorsal surface of the tail [emphasis added]. In addition, the photographs of Myers' and Donnelly's own specimens show variation in the width of the middorsal stripe. For example, it is narrow in AMNH 14133 [sic (presumably 141331, a juvenile)]. Of the specimens reported here, the middorsal stripe of MHNLS 11387 (juvenile male from Serranía de Yutajé) is only 1 scale wide at the nape, 2 scales wide at midbody and 3 scales wide above the inguinal region. (Gorzula and Señaris, 1999: 140-141)

Stripe width on the tail is not relevant to the present discussion, and the Yutajé juvenile described above obviously has the stripe posteriorly widened on the body, as does our juvenile specimen from Cerro Yutajé (fig. 40, left). Lancini (1968: 3) said that the middorsal stripe of phelpsorum was up to two scales wide (hasta dos escamas de anchura), which seems consistent with his photograph showing a median stripe that is apparently narrow for the length of the trunk. An enlarged copy of Lancini's photograph of Prionodactylus phelpsorum is reproduced in figure 43, in side-by-side comparison with the adult type specimens of Prionodactylus goeleti. The phelpsorum holotype is obviously more robust than the specimens of $P$. goeleti, but that may be due to a combination of gravidness and distention with preserving fluid. In any case, despite the oblique view, it seems clear that Lancini's description of the median stripe was accurate, and that this stripe is not posteriorly expanded in $P$. phelpsorum.

Myers and Donnelly (1996: 30-31) took what they could from Lancini's overly brief description of the phelpsorum holotype (which is lost according to verbal communication from Alfredo Paolillo) and pointed out similarities with goeleti. The only differences were the obvious one in adult middorsal-stripe width, a slight difference in dorsalscale count (40 in one phelpsorum, 33-38 in six goeleti), a possibly subjective difference in degree of keeling, and an apparent difference in ventral coloration.

Only the last character above was used as a secondary diagnostic character for differentiating goeleti from phelpsorum, and it de- 

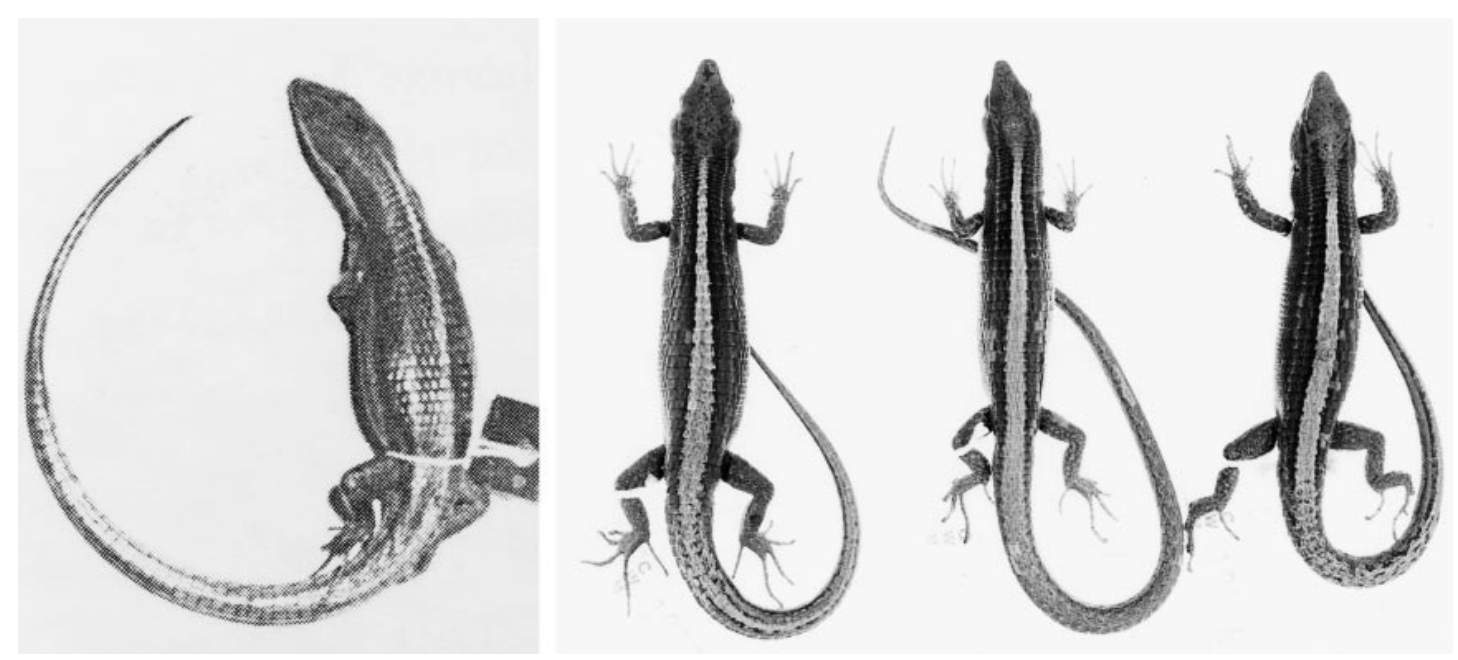

Fig. 43. Adult dorsal color patterns of type specimens of Prionodactylus phelpsorum (holotype $q$, first specimen on left) and Prionodactylus goeleti (next three specimens, from left to right: EBRG 3112 q [holotype], AMNH 141330 ㅇ, 141329 ${ }^{\star}$ ). Holotype of $P$. phelpsorum enlarged $\times 2.6$ from photograph in Lancini (1968: fig. 7); specimens of P. goeleti from Myers and Donnelly (1996: fig. 18).

pended on an interpretation of Lancini's description. As also noted by Gorzula and Señaris (1999: 141), Lancini "did not describe the ventral color of the body, but simply stated that it was similar to that of the tail which was 'gris plomizo salpicado de negro' (slate gray with black speckling)." In contrast, topotypic adult female goeleti were either white or bluish white under the head, and greenish white on other ventral surfaces, except for a tinge of orange under the tails. Gorzula and Señaris (1999: 141) quoted Gorzula's fieldnotes describing the ventral coloration of another female from Cerro Yaví as "pale yellowy brown", and then obfuscated the matter by discussing ventral color in juveniles (pale green as described for the juvenile paratopotypes or "dirty pale grayish green with faint gray dusting" in a juvenile male from Cerro Corocoro). Gorzula and Señaris concluded their discussion of ventral color by saying that "Such variation is not convincing to diagnose a new species."

Nonetheless, an adult female ventral color of slate gray in life is suggestive to us of taxonomic difference when compared with a geographically remote population in which female venters are pale greenish white or "pale yellowy brown". But we took Lancini at face value that the throat and venter of the female specimen of phelpsorum were slate gray in life, and assumed that if the ventral ground color in life had been pale he would have said so. If, however, he had misleadingly extrapolated ventral color from the preserved specimen, it would be a different matter, since female goeleti became light gray in preservative "apparently owing to expansion of melanophores that were not evident in life" (Myers and Donnelly, 1996: 27). Obviously, posterior widening of the middorsal stripe-most evident in adults, albeit present in juveniles-is probably the most reliable character for separating Prionodactylus goeleti from $P$. phelpsorum (fig. 43). The $a b$ sence of a middorsal stripe seems to distinguish a third tepui species, as discussed below.

Gorzula and Señaris (1999: 129-139) described Prionodactylus nigroventris from $1650 \mathrm{~m}$ elevation on Cerro Guanay, a neighboring tepui immediately to the northwest of the Yutajé-Corocoro massif (fig. 1). The type series of $P$. nigroventris comprised one adult male, a subadult male, and a subadult female. The new species was compared with $P$. goeleti (as "phelpsorum") - its nearest geographic relative-only in the Diagnosis, where $P$. nigroventris was said to differ by having a "dark black venter in adult males 
(orange in $P$. phelpsorum) and 6 to 9 rows of temporals between the middle postocular and the scales bordering the ear opening."

The comparison of the black venter of adult male nigroventris with the orange venter of adult male phelpsorum seems based on two specimens-the nigroventris holotype and our earlier description of a male goeleti, which developed extensive black ventral coloration after preservation (Myers and Donnelly, 1996: fig. 18, lower right). Concerning the temporal scales, Gorzula and Señaris did not give data for phelpsorum/goeleti, but lateral head drawings of two nigroventris do not show the temporal scales as being clearly organized in rows. However, the lateral head views shown by Gorzula and Señaris (1999: figs. $17 \mathrm{~b}, 18 \mathrm{~b}$ ) for $P$. nigroventris do bear some resemblance to a drawing of $P$. goeleti, which was described as having the "Temporal region between postoculars and ear opening with about 15-25 irregularly shaped juxtaposed scales, of which the upper ones are large and the lower ones small to medium in relative size" (Myers and Donnelly, 1996: 26 and fig. 17). The smallest scales are wedged obliquely from near the postoculars toward the corner of the mouth. But there are other characters not discussed.

Examination of the description of $P . n i$ groventris reveals an especially striking difference between it and the other tepui species (i.e., P. goeleti and P. phelpsorum [as well as the extralimital $P$. vertebralis, fig. 42 , bottom]). Prionodactylus nigroventris evidently lacks the pale middorsal stripe that is so conspicuous in the other species! We admittedly extrapolate, since Gorzula and Señaris neither published a photograph nor explicitly stated that nigroventris lacks a pale middorsal stripe, but its absence has to be assumed from their description: In life, "Dorsum of head dark brown. Dorsal scales brown, slightly lighter than the head. Dorsolateral scales greenish yellow, forming two dorsolateral lines" (Gorzula and Señaris, 1999: 137).

Therefore, as described by Gorzula and Señaris, the dorsal color pattern of their Prionodactylus nigroventris seems to be much like that of the generic type species, $P$. manicatus (fig. 42, middle) from western South America. The absence of a median stripe should immediately separate $P$. nigroventris from the other two tepui species.

\section{FAMILY TROPIDURIDAE}

Only one species of tropidurid lizard was obtained by the 1995 AMNH-TERRAMAR Expedition. It is close to a species that we previously named in the genus Plica (Donnelly and Myers, 1991), which subsequently was placed in the synonymy of Tropidurus by Frost (1992).

Tropidurus panstictus, new species Figures 44A, 45-48

Holotype: EBRG 3130 (field no. CWM 19795), an adult male from south end of Cerro Corocoro, $1220 \mathrm{~m}\left(5^{\circ} 42^{\prime} \mathrm{N}, 66^{\circ} 10^{\prime} \mathrm{W}\right)$, Amazonas, Venezuela; collected March 1, 1995, AMNH-TERramar Expedition. See locality 2 on map (fig. 1).

PARATOPOTYPES: AMNH 147040-147045, EBRG 3128-3129, 3131-3132, from same locality as holotype, collected February 28March 1, 1995, AMNH-TERRAMAR Expedition.

PARATYPES: AMNH 147046, EBRG 31333134, from above Yutajé, Río Corocoro, 180 $\mathrm{m}\left(5^{\circ} 37^{\prime} \mathrm{N}, 66^{\circ} 07^{\prime} \mathrm{W}\right)$; collected March 2, 1995, AMNH-TERRAMAR Expedition. See locality 3 on map (fig. 1).

ETYMOLOGY: The species name panstictus is an adjective derived from the Greek pan(all, all over) + stiktos (dappled, spotted, punctured), in allusion to the profuse speckling and spotting over the head, body, and limbs of adults.

Diagnosis: A large Tropidurus having several tufts of elongate, spinous scales on the neck; complete gular and antegular folds; anteriorly imbricate head scales; small, slightly imbricate, acutely pointed, thornlike body scales; and a middorsal crest from rear of head onto the tail.

Tropidurus panstictus most nearly resembles $T$. lumarius, from which panstictus differs in larger size and a different color pattern, which is much lighter and which includes profuse pale speckling in adults (see later, under Comparison with Tropidurus lumarius). Tropidurus panstictus differs from other spiny-necked tropidurines in the same way that $T$. lumarius does (Donnelly and 
Myers, 1991: 31-32). We provide a key to Venezuelan tropidurines following the $\mathrm{Re}$ marks section.

\section{Size AND PROPORTIONS}

Head large, head length (measured obliquely from tip of snout to angle of jaw) $26-30 \%$ of SVL; head longer than wide and wider than high, wider than neck; neck narrower than body. Snout rounded to broadly rounded in dorsal view, not projecting over mouth. Body wider than deep. Limbs long and slender, pentadactyl; relative finger and toe lengths $4>3>2>5>1$. Tail 1.6-2.1 times SVL; tail becoming slightly vertically compressed and then rounded toward end. Four adult males with maximum snout-vent length of $119 \mathrm{~mm}(96-119 \mathrm{~mm}, \bar{x}=108.3$ $\mathrm{mm}, \mathrm{SD}=9.6)$. One adult female $93 \mathrm{~mm}$ SVL, five juvenile males 62-94 mm SVL, two juvenile females 66-71 $\mathrm{mm}$ SVL, and two unsexed juveniles 40-54 $\mathrm{mm}$ SVL.

\section{Squamation, Pockets, and Folds}

HEAD (fig. 44A): Interparietal large, roughly triangular, wider than long or longer than wide; posteriorly bordered by $1-3$ rows of small smooth or rounded scales separating the interparietal from small pointed scales on rear of head; laterally in contact mainly with irregularly shaped smooth scales. Scales of interocular and frontonasal region irregularly shaped, usually smooth (with sensory pits), occasionally a few scales keeled; weakly imbricate anteriorly; 2-3 rows between circumorbital series (three in holotype). Circumorbitals mainly in 2 rows, inner row with largest scales, anteriormost and especially posteriormost scale in inner (and sometimes outer) row often resembling adjacent supraoculars in being longer than wide. Three or (usually) four large supraoculars (4/3 in holotype). Superciliaries longer than high, in three stacked rows; scales in middle row largest; superciliaries forming a laterally or dorsolaterally projecting crest extending beyond orbit.

Nasals separated from rostral and first supralabial by 1-2 scales. Rostral separated from internasals by 1-2 rows of postrostral scales. Internasals about 15-23 in 3-4 vague rows (holotype, 18 scales in 4 rows). Super- ciliary series terminates in a single large canthal; canthal separated from nasal by $1-2$ scales. Loreal region with 6-13 small to moderate-sized smooth scales with pits. Lorilabials in 3-6 rows. Enlarged median suboculars 4-6; suboculars keeled (with sensory organs on keels). Temporal region with moderate-sized keeled or pointed scales, which imbricate anteriorly. Rostral much wider than high, little higher than adjacent supralabial. Supralabials 4-6, usually 4/4 (as in holotype).

Mental scale projecting slightly posteriorly beyond anterior margins of adjacent infralabials. Postmental series not well defined. Infralabials 5-7, usually 5/5 (as in holotype, which has second infralabial on right partially divided). Gular scales smooth, increasing in size anteriorly and laterally; lateral gulars laterally imbricate; anterior gulars anteriorly imbricate; medial posterior gulars imbricate posteriorly, then grade into conical and pointed granules, with pointed granular scales to either side.

TYMPANUM: Ear canal moderately deep, opening higher than wide; a tuft of 4-6 large pointed scales at anterior margin; usually two tufts of large pointed scales near posteroventral margin, sometimes merged into an obliquely elongated larger tuft. Internal rim of ear canal anteriorly lined with small smooth scales; dorsal, ventral, and posterior rim lined by smaller, smooth or weakly keeled, elongate scales.

NECK: Nape with anteriorly imbricate small pointed scales (large granules). Side of neck with pointed granules, anterior ones dorsally imbricate, becoming posteriorly imbricate caudad. Two tufts of elongated spiny scales more or less in line with upper edge of ear opening; spines in anteriormost tuft largest; posteriormost tuft situated at terminus of oblique neck fold.

POCKETS AND FOLDS: Terminology following Frost (1992: 25-27): Antegular fold complete (faint in smallest juvenile), although sometimes interrupted medially by longitudinally raised ridge of granules extending posteriad from throat; antegular fold overlapping or lying just anterior to the gular fold. Antegular fold continuous with oblique neck fold, which terminates in posteriormost tuft of scales on side of neck. Lateral mite pocket 

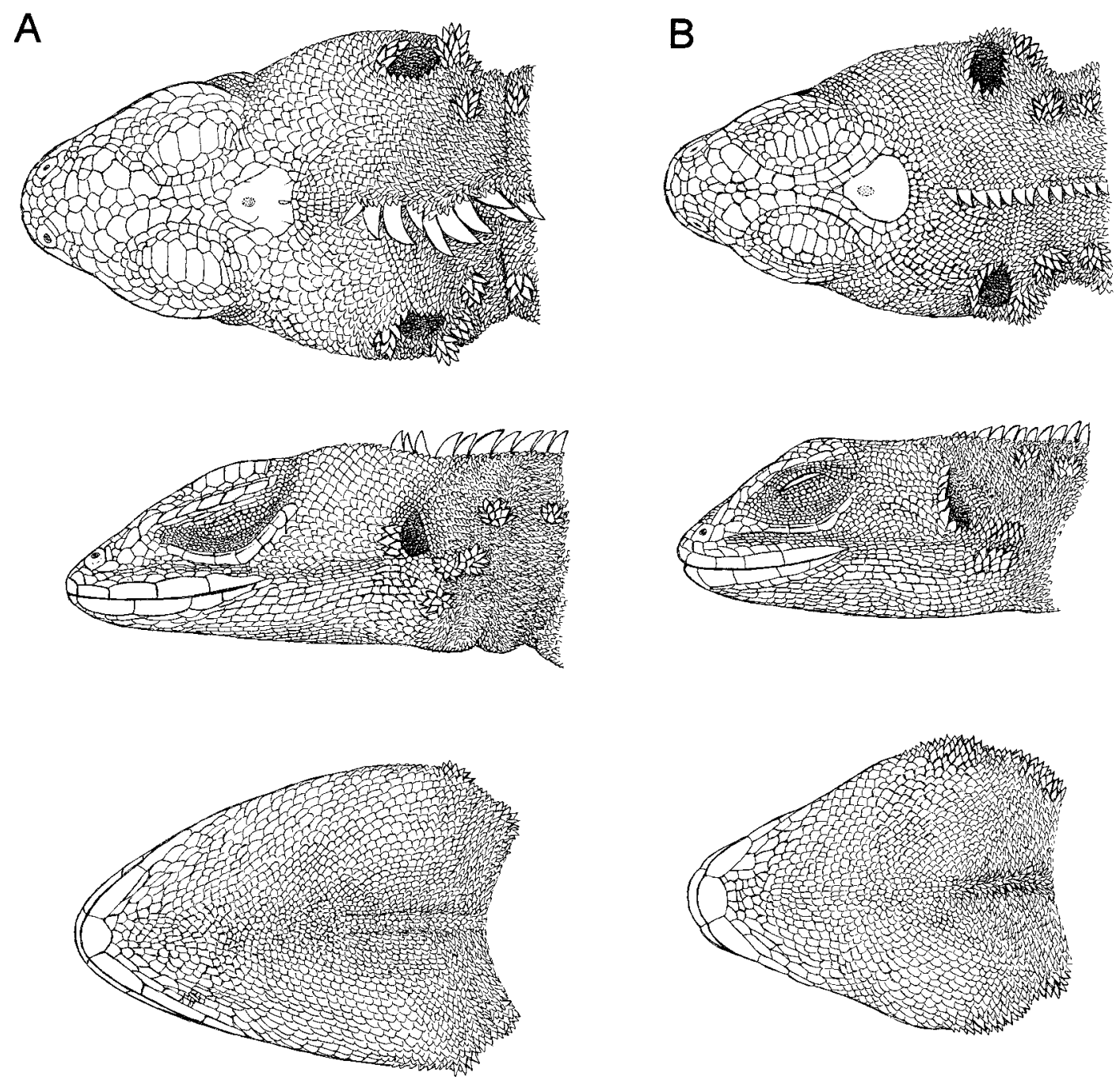

Fig. 44. Dorsal, lateral, and ventral views of heads of adult male holotypes. A: Tropidurus panstictus, new species (EBRG 3130 $\hat{\circ}, 111 \mathrm{~mm}$ SVL). B: Tropidurus lumarius Donnelly and Myers (AMNH 136176, $98 \mathrm{~mm} \mathrm{SVL).} \mathrm{Scale} \mathrm{line}=10 \mathrm{~mm}$ for both.

present, under junction between antegular and oblique neck folds. Gular fold complete, its lateral mite pocket continuing under the antehumeral fold. Scales lining folds not (or but little) reduced in size, except for tiny smooth granules in mite pockets. Rictal fold present. Dorsolateral fold present, anteriorly continuous with antehumeral fold; granular scales on dorsolateral fold elongate and pointed, somewhat larger than other body scales. Weak ventrolateral fold present, its scales little larger than other body scales. No mite pockets in axilla or groin.

BODY: Middorsal crest of laterally compressed, long pointed scales directed posterodorsally, starting about 3-7 scales behind interparietal and continuing onto tail; crest scales on body about $68-89(\bar{x}=76.2)$, usually decreasing in height posteriorly and then increasing somewhat on base of tail. Middorsal crest present on all specimens, being best developed in adult males and weakly de- 
veloped in small juveniles, in which enlarged crest scales are prominent but are not elevated.

Body to either side of middorsal crest with slightly imbricate, acutely pointed scales directed posterodorsally. Paravertebral scales (from posterior edge interparietal to level of posterior margin of thigh) 153-175 $(\bar{x}=$ 169.7). Scales around midbody $143-164(\bar{x}$ $=157.0$ ).

Ventral scales larger than dorsals and smooth; ventrals somewhat irregularly shaped, those on anterior venter usually posteriorly pointed and imbricate, often becoming quadrangular and subimbricate on posterior belly, in wavy transverse rows only; $30-36$ scales across chest $(\bar{x}=32.2)$; 95-116 transverse rows from gular fold to vent $(\bar{x}=$ 108.5). Umbilical scar still present in smallest juvenile (40 $\mathrm{mm}$ SVL).

LIMBS: Dorsal surface of upper arm with moderate-sized, imbricate, acutely pointed scales, much larger than granular body scales. Dorsal surface of forearm with larger, imbricate scales, weakly to sharply keeled, slightly mucronate; scales on lateral side of forearm with mucrones elevated and acutely pointed. Elbow scales smooth. Ventral side of arm with moderate-sized, imbricate, smooth scales, sometimes faintly mucronate. Top of hand with smooth (some slightly mucronate) imbricate scales, some scales becoming keeled distally on fingers; palm with either smooth or weakly keeled scales, tending to be distally elevated and mucronate. Subdigital lamellae single, tending to be bicarinate on fingers I and II, becoming tricarinate on fingers III-V, distally changing to carinate. Subdigital lamellae of fourth finger 23-30 $(\bar{x}=26.1, \mathrm{SD}=2.04)$.

Dorsal and posterior thigh with small pointed scales not much larger than granular body scales; raised scale points (and direction of imbrication) projected posteriorly on top of thigh, dorsally on posterior thigh. Anteroventral thigh with larger smooth scales (some slightly mucronate) imbricating toward knee; ventral thigh with smooth scales posteriorly imbricate. Lower leg scales keeled and mucronate on upper surfaces, smooth on ventral side, all imbricate toward foot. Knee scales smooth, smaller than adjacent dorsal or ventral scales. Dorsal scales of foot proximally small, essentially smooth, distally becoming larger, keeled, mucronate. Sole with smooth, slightly mucronate scales. Subdigital lamellae with carination similar to that of fingers. Subdigital lamellae of fourth finger $31-39(\bar{x}=34.8, \mathrm{SD}=2.26)$.

TAIL: Enlarged middorsal crest scales continuous from body crest, declining in size posteriorly; distinct on anterior third to half of tail. Dorsal and lateral caudal scales posterodorsally imbricate or subimbricate, acutely pointed on base of tail, becoming weakly mucronate distally. Subcaudal scales posteriorly imbricate, smooth, becoming weakly keeled toward tip of tail.

\section{Coloration}

In life (or shortly after death, fig. 45), ${ }^{27}$ head of adults with black, light yellow, yellowish brown, or greenish markings, including a small to large pale spot on the parietal in all. A variably configured and broken black nuchal collar and a V-shaped scapular band (posterior to antehumeral folds). Dorsal surfaces of body greenish gray or light brown, with several ill-defined blackish blotches (posterior to scapular band) visible on middorsum of the lighter specimens. Dorsum and sides overall densely and rather uniformly speckled with small spots and dots of pale tan, pale yellow, or pale green.

Limbs colored like dorsa, with black or grayish brown bands on the paler ground color; bands on forelimbs tending to be darker and better defined than those on hind legs. Dark tail bands on the lighter ground color.

Underside of head with black markings on variable ground color of pale green, or bluish gray, or yellow on chin and orange on throat. Ventral surface of body and limbs bluish white, with an ill-defined but conspicuous suffusion of orange along ventrolateral sides of venter and under tail. Iris brown, tongue and mouth lining unpigmented.

A juvenile paratopotype (fig. 47) had a grayish head with brown markings, promi-

\footnotetext{
${ }^{27}$ Color in "life" is based on transparencies and fieldnote descriptions made by daylight, from dead or stunned upland paratopotypes that had been recently collected with .22-caliber dustshot. A few lowland paratypes reached camp after dark and were only photographed (fig. 46).
} 

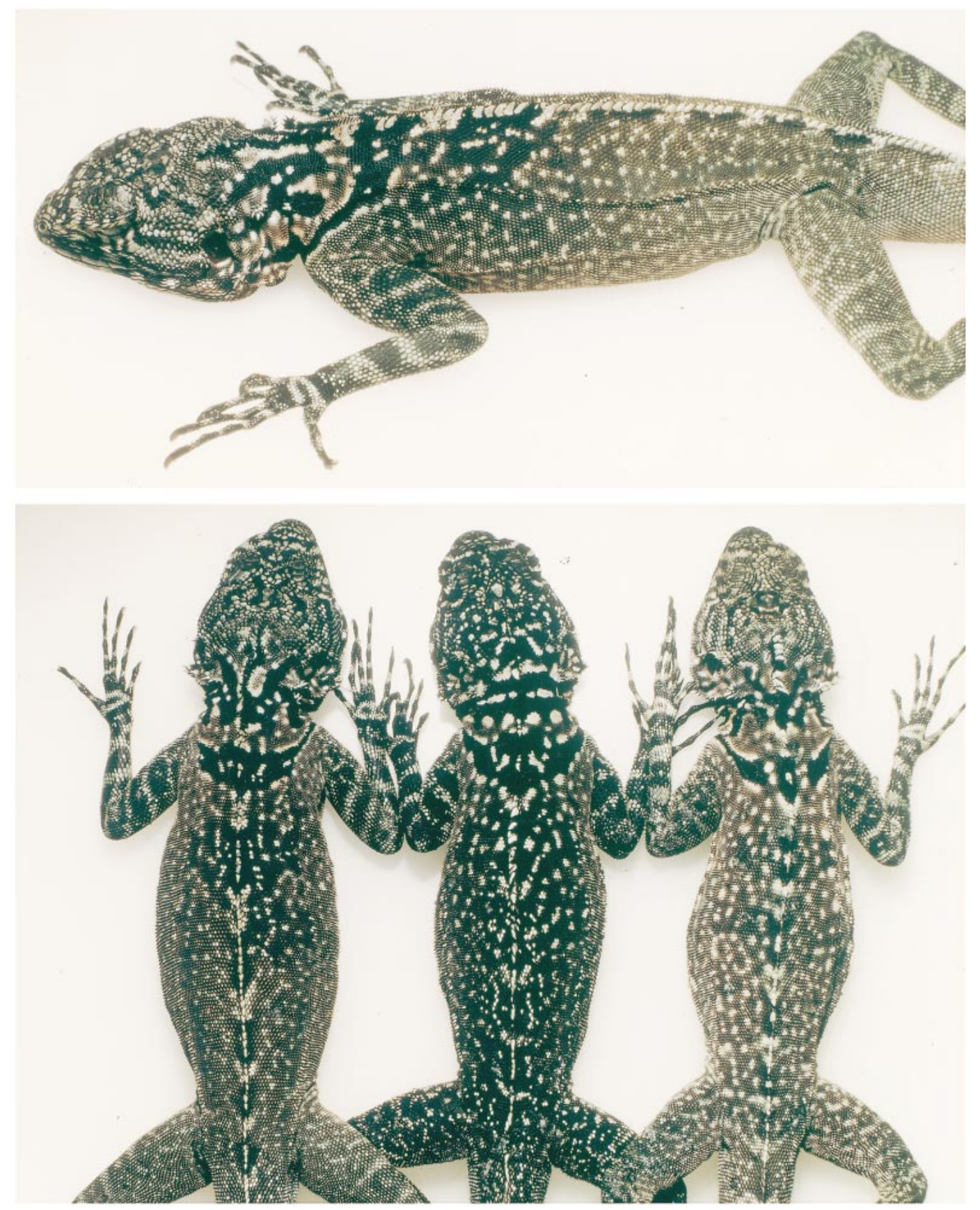

Fig. 45. Tropidurus panstictus, new species. Coloration of adult males before preservation. Top: Holotype (EBRG 3130) in dorsolateral view. Bottom: Dorsal view, left to right, EBRG 3130 (holotype), AMNH 147041, 147042 (paratopotypes). 


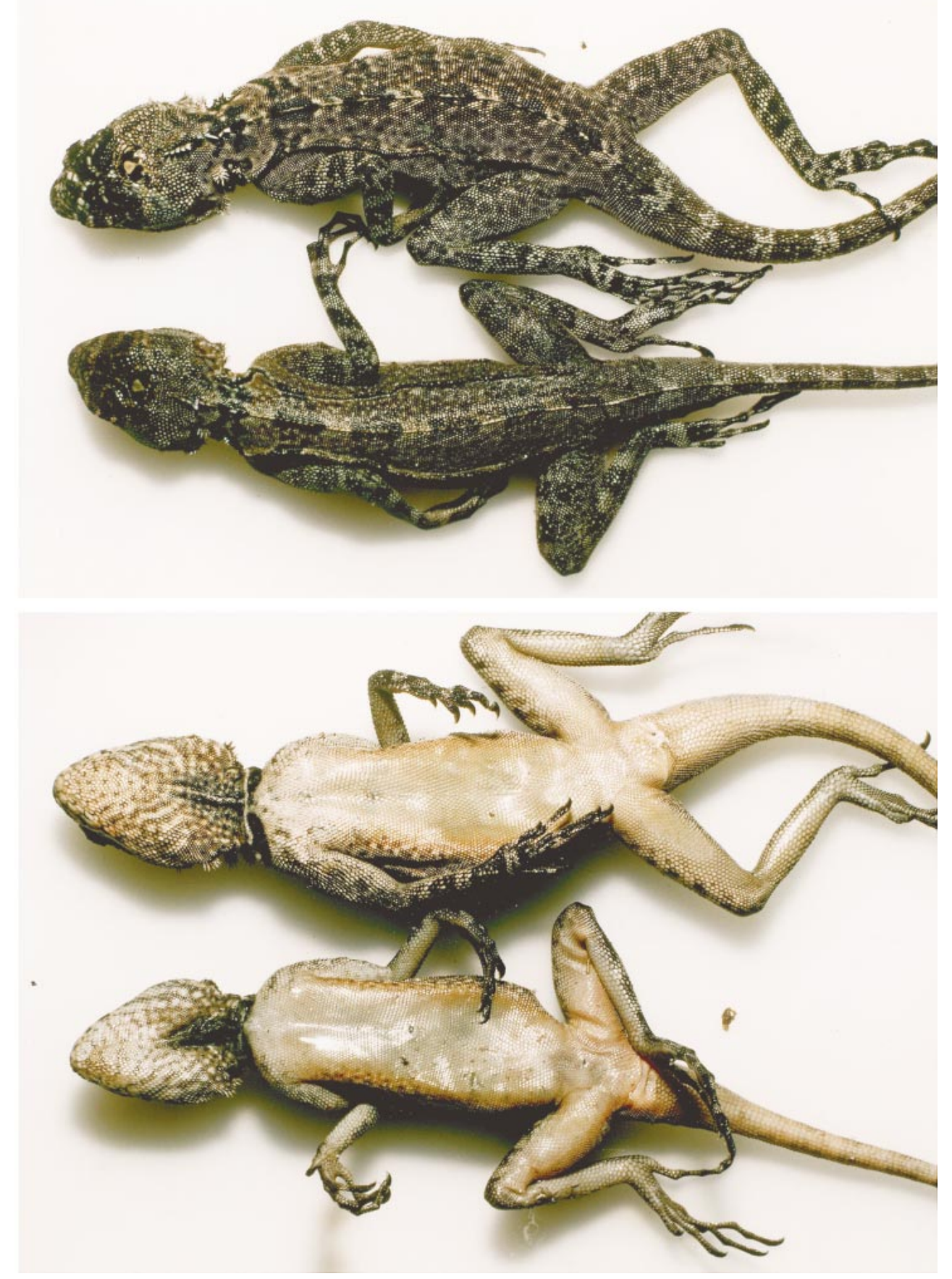

Fig. 46. Tropidurus panstictus, new species. Dorsal and ventral views of lowland paratypes, EBRG $3133 \hat{0}$, AMNH 147046 ㅇ (lower). 


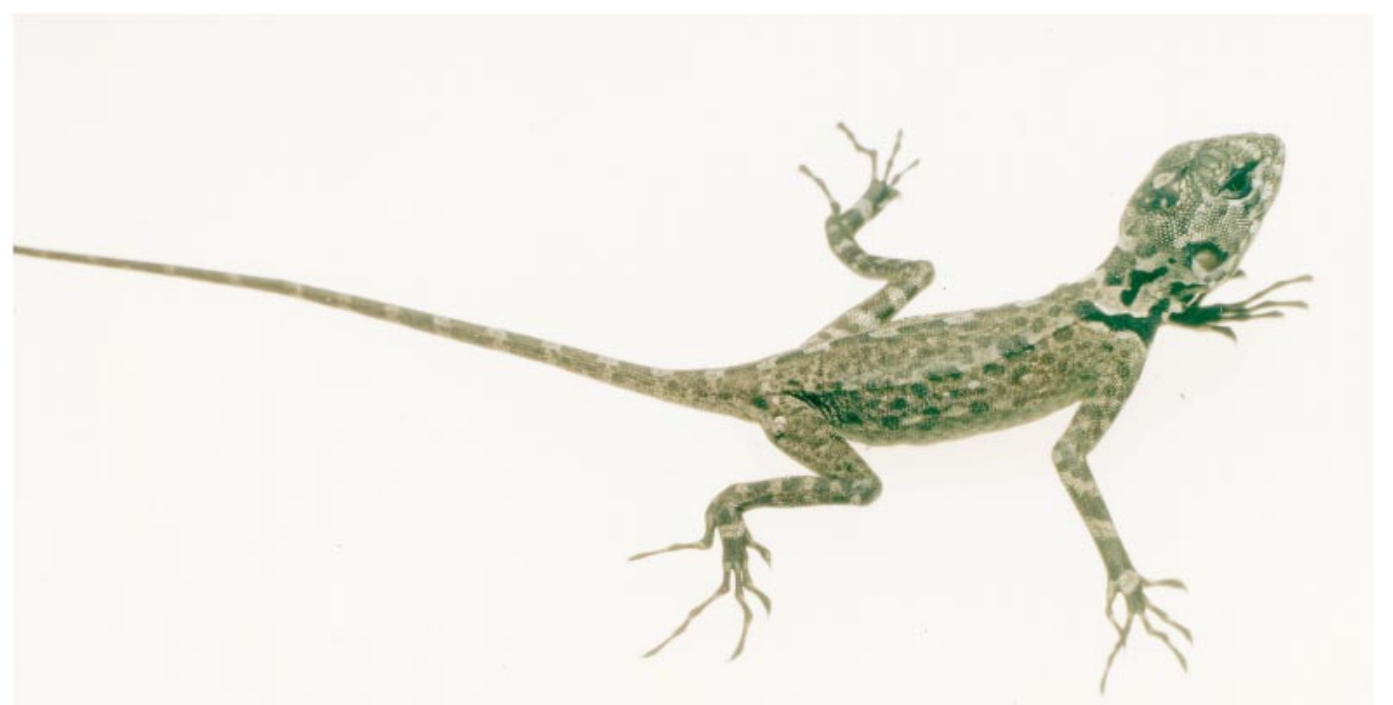

Fig. 47. Tropidurus panstictus, new species. A juvenile paratopotype (AMNH 147045, $40 \mathrm{~mm} \mathrm{SVL}$ ). Compare with color pattern of adults (figs. 45, 46).

nent black nuchal and scapular markings, and a light brown body with darker brown, round spots; the limbs and tail were light brown with darker brown bands.

In preservative, dorsal ground color grayish brown to blackish, with numerous light spots and flecks scattered over body, except light flecking inconspicuous in smaller juveniles. Collar and cape often emphasized by light internal spots and edging of light markings. Three to five irregular dark middorsal blotches on body posterior to scapular band, sometimes (especially in juveniles) with irregular smaller blotches on sides; dorsal markings often vague. Light interorbital bar (anterior to supraocular scales) present in all, distinct in most ( $\mathrm{V}$-shaped in one); a less distinct light bar across snout discernible in most. A light triangular to round, small to large parietal spot, usually distinct. Light spots or one or two light lines from eye to upper lip; a dark-edged light stripe or a few light lines on side of head from eye to ear; upper lip black with light spots (still showing yellow or light blue color in a few) distinct or vague; lower lip spotted black or gray.

Larger specimens with large black spot on base of throat, this spot smaller or absent in others. Underside of head rather densely marked with gray lines or spots tending to radiate forward and outward from black spot (when present) or from base of throat. A midventral dark-edged, light gular line in some specimens, extending from middle of throat to base.

Forelimb, especially lower arm, with distinct black bands and narrower light interspaces. Hind legs usually less distinctly banded. Venter and undersides of limbs and tail cream, often with light gray suffusion. Tail bands distinct in smaller individuals.

\section{HEMIPENIS}

The right hemipenis of a paratopotype (AMNH 147041), which had been partially everted in the field, was detached from the specimen and softened in a solution of $\mathrm{KOH}$. After removing as much of the major retractor muscle as possible, the organ was inflated with red-dyed petroleum jelly. Each lobe had to be manually everted separately, and each lobe ruptured at its delicate apex. The complete eversion otherwise was successful, as shown in figure 48.

The hemipenis is tiny considering the size of the adult male (119 mm SVL). When straightened from its curved position, the organ measures about $11 \mathrm{~mm}$ from the base to the tip of one lobe. It is divided for about half of its length. The sulcus spermaticus bifurcates proximal to the crotch, and the sulcus branches diverge in centrolineal orientation and extend apparently to the tips of the 

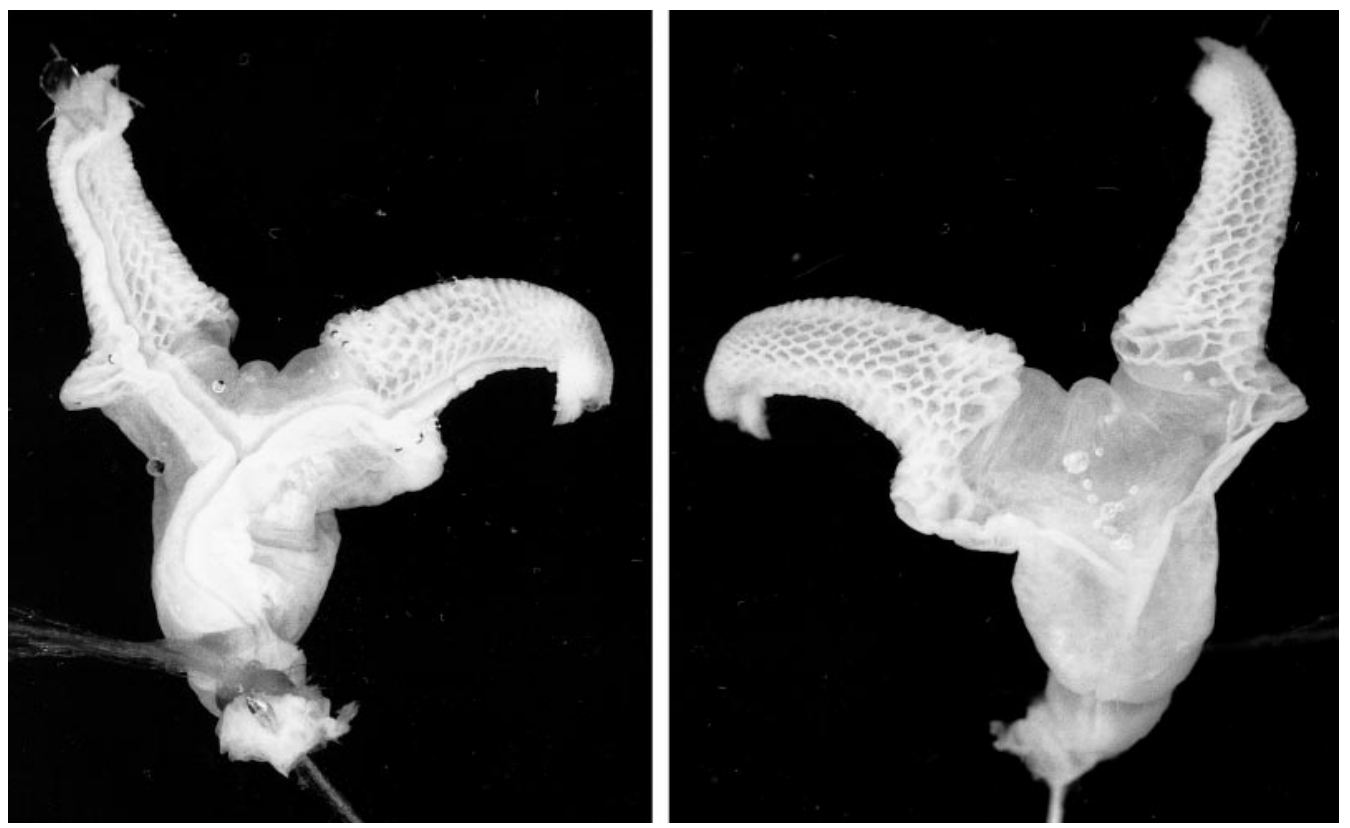

Fig. 48. Hemipenis of Tropidurus panstictus, new species Right organ of AMNH 147041 (paratopotype, $119 \mathrm{~mm} \mathrm{SVL}$ ), in sulcate and asulcate view, $\times 7.9$.

lobes. The basal stalk of the hemipenis lacks ornamentation; there are thin lateral alae on the sides of the stalk, extending from about halfway up the stalk and terminating at the base of each lobe.

The lobes are nearly fully calyculate, from shortly above the base of each lobe, with the calyces decreasing in size distally from the large basal calyces. The calyculate areas are confined to the lobes and are widely separated across the nude crotch.

\section{COMPARISON WITH TROPIDURUS LUMARIUS}

Tropidurus panstictus is most similar to $T$. lumarius from Cerro Guaiquinima, about 300 $\mathrm{km}$ east of the Yutajé-Corocoro massif, on the other side of the Sierra de Maigualida. Tropidurus panstictus is a larger species: Four adult male panstictus average 108.3 mm SVL (96-119 mm), compared with a mean of $88.5 \mathrm{~mm}(76-100 \mathrm{~mm})$ for four adult male lumarius. One adult female panstictus measured $93 \mathrm{~mm}$ SVL, compared with a range of $76-79 \mathrm{~mm}(\bar{x}=77.1)$ for five adult female lumarius. The difference in SVL appears to be correlated with a relatively stockier head and body in $T$. panstictus.
Apart from size, it is hard to find consistent differences in the morphology of these two lizards. Differences seen when comparing one individual with another mostly disappear when intrapopulational variation is considered. For example, when comparing heads of the holotypes (fig. 44), there are visible differences in the disposition of spinous scales on the anterior ear margin, and in alignment of the two spiny tufts on the neck, but these traits are variable in each species. The elongate spines on the granular neck and body scales seem to us to be longer in $l u$ marius than in panstictus, but any difference would be tediously difficult to quantify. One difference, although not an absolute one, involves the nature of the tiny scales in contact with the rear margin of the large interparietal. In $T$. lumarius, the interparietal usually is in contact with small pointed scales anterior to the middorsal crest, but sometimes a row of small smooth scales intervenes. In $T$. panstictus, there usually are 2-3 rows of small smooth scales separating the interparietal from the small pointed scales, but sometimes there is only one such row, as in lumarius. Such a difference, not detectable in the draw- 
ings (which cannot show elevated points or mucrones on granular scales at the magnification drawn), would seem both biologically and taxonomically insignificant.

Differences in living coloration are pronounced. Tropidurus lumarius is essentially a black lizard, with small yellowish spots and dots, which are frequently coalesced to form ill-defined transverse bars or rows of spots on the body and tail or narrow crossbars on the limbs. Adult males have golden yellow patches on the posterior belly, preanal area, and undersides of thighs, whereas females have a pink wash in the same area.

Tropidurus panstictus differs from the above in having a lighter ground color and (especially in adult males) a profuse dappling of small light spots and dots that do not coalesce to form bars or rings (figs. 45, 46). Rather than golden yellow ventral patches as in lumarius, adult male panstictus are suffused with orange ventrolaterally and under the tail. Some specimens of panstictus have dark dorsal spots and other dark markings not observed in lumarius.

Both species share variable but similar black nuchal and scapular markings, but these tend to be obscured in Tropidurus lumarius and more prominent in $T$. panstictus. Direct comparison of the hemipenes suggests that the organ of $T$. panstictus (fig. 48) is virtually identical to that of $T$. lumarius (Donnelly and Myers, 1991: fig. 18), although the latter organ is less well prepared. The earlier published drawing for T. lumarius shows only representative calyces on the lobes, which prove to be incompletely everted; the calyculate areas resemble those in $T$. panstictus (fig. 48).

\section{REMARKS}

We described Tropidurus lumarius from 14 specimens that we collected on the summit of Cerro Guaiquinima in 1990 (Donnelly and Myers, 1991) on an expedition sponsored by the Fundación para el Desarrollo de las Ciencias Físicas, Matemáticas y Naturales (FUDECI); this expedition included different groups of scientists working on various projects during different times, with no coordination between groups. We were not informed that a German group had been sched- uled to work on amphibians and reptiles before us; later, we were given reason to believe that their interests were not systematic. We were unaware that a professional herpetologist was involved with the German effort, and we certainly made a mistake in not pressing for more particulars on the German party and in not trying to make contact - we probably missed a chance at fruitful collaboration. But we thought no more about it until we saw in late March, 1991, their collection report that had been published a month earlier (Mägdefrau et al. 1991). We were surprised by their report-as they doubtless also were when our own report appeared several months later on June 28 (Donnelly and Myers, 1991). A short paper by Mägdefrau (1991) appeared a few days after that, with the description of Plica nigra, a junior synonym of $T$. lumarius (synonymy by Frost, 1992: 5). This hapless duplication of effort, and a comparison of collection results, is discussed in a postscript to our 1991 paper. The only reason for bringing it up again emanates from insinuations made recently by Gorzula and Señaris (1999: 153).

Among other things, these authors complained that Gorzula had collected the first specimens of Tropidurus lumarius/nigra six years before the 1990 FUDECI expedition, and that unnamed persons in FUDECI were aware that he had been planning to describe the new lizard. Gorzula and Señaris (1999: 153) asserted that "Certainly by late 1990 , staff of both the AMNH and the ZSM were aware of the series of [Gorzula's] specimens collected in 1984 and 1985." This statement is fabricated! We did not learn of Gorzula's earlier collection of this lizard on Cerro Guaiquinima until much later, long after the 1991 publications (Mägdefrau et al., 1991; Mägdefrau, 1991; Donnelly and Myers, 1991), and we have no reason to believe that our German colleagues knew of it either. In 1995, Gorzula first complained about the matter in a letter to Myers; in that letter, Gorzula did not mention FUDECI, but twice laid the blame on unidentified persons in TERRAMAR, where "I spent a whole morning giving them maps of Guaiquinima and telling them where and what I had collected" (letter, Gorzula to Myers, August 24, 1995). In response, Gorzula was advised that (1) it had 
been not a TERRAMAR but a FUDECI-sponsored expedition, and that we had had no association with TERRAMAR in 1990; (2) his information had not been passed on to us (by either institution); and (3) that his prior manuscript name would have been honored had we known about it. ${ }^{28}$ There is much water under such bridges.

Tropidurus panstictus is not endemic to Cerro Yutajé, but occurs also on neighboring Cerro Guanay (Myers and Donnelly, in progress).

\section{Key to Venezuelan Tropidurid Lizards}

With the present description of Tropidurus panstictus, eight species of tropidurid lizards - all members of the tribe Tropiduriniare known from eastern Venezuela. One species is in the monotypic genus Uranoscodon, which was considered by Frost (1992) to be the sister taxon of all other genera of Tropidurini. The remaining seven species are currently assigned to Tropidurus following Frost (1992), who substantially extended the concept of this genus by placing Plica and Uracentron in its synonymy.

Three of the eight tropidurines in Venezuela are endemic, but the others are wideranging lizards that are illustrated by color photographs and line drawings in Avila-Pires (1995). The following key is based on a few easily discerned characters. Asterisks indicate species that have been found on tepuis; a double asterisk denotes species that appear to be endemic to particular tepuis.

\section{Tail "normal" (compressed or not)-slender} and gradually tapering, longer than snoutvent length (SVL) ............ 2

- Tail depressed and much shorter than SVL, wide for most of its length and armored with whorls of spiny scales; Amazonian lowland forest .......... Tropidurus [Uracentron] azureus (Linnaeus)

2. No projecting tufts of elongate, spinous scales on neck ............ 3

${ }^{28}$ Two-page letter, Myers to Gorzula, February 2, 1996; receipt acknowledged by Gorzula on July 27 , 1996; also unanswered letter, Myers to Gorzula, March 22, 2000, with copies attached of pertinent 1991 letters to FUDECI and 1991 and 1993 letters between Myers and Andreas Schlüter, Stuttgart. (Correspondence in AMNH Dept. Herpetology Archives, Myers collection, Gorzula folder.)
- Spiny tufts present on neck ........ 5

3. No middorsal crest; widespread in open country and dry forest .............. ......... Tropidurus hispidus (Spix)*

- Middorsal crest of enlarged scales present; lowland forest in Amazonas and Bolívar

................... 4

4. Body and tail rounded $\ldots \ldots \ldots \ldots \ldots \ldots$ ......... Tropidurus umbra (Linnaeus)

- Body and tail laterally compressed ..... . ... Uranoscodon superciliosus (Linnaeus)

5. Prominent middorsal crest of enlarged scales; gular fold medially complete, with mite pocket in fold laterally .........6 6

- Middorsal crest absent; gular fold incomplete medially, lacking a mite pocket in fold; Auyantepui .... Tropidurus bogerti Roze**

6. Mainly grayish to black in life, without a bold dark pattern (dark bands lacking, inconspicuous or very fragmented on body); a tuft or line of markedly enlarged scales projecting from anterior edge of ear opening $\ldots \ldots \ldots \ldots \ldots \ldots \ldots \ldots \ldots \ldots \ldots \ldots$

- Mainly green in life, with conspicuous dark brown or blackish bands (often broken) on body and limbs; enlarged scales not projecting from anterior edge of ear opening; geographically widespread ......... ......... Tropidurus plica (Linnaeus)*

7. Mainly black in life and death, sparsely marked with small yellowish spots; SVL to about $79 \mathrm{~mm}$ in females, $100 \mathrm{~mm}$ in males; Cerro Guaiquinima ....... Tropidurus lumarius Donnelly and Myers**

- Lighter gray or brownish with more conspicuous dark markings, and (in adults) with dense and uniform distribution of small spots or speckling of pale tan, yellow, or green; larger, SVL to at least $93 \mathrm{~mm}$ in females, $119 \mathrm{~mm}$ in males; Yutajé-Corocoro massif, Cerro Guanay, and perhaps adjacent areas ...... Tropidurus panstictus, new species*

\section{SNAKES}

\section{FAMILY COLUBRIDAE}

\section{Liophis species?}

Material: No specimen collected. A small snake of Liophis size was seen by John Daly one day at the type locality of Colostethus undulatus (q.v.), at $1750 \mathrm{~m}$ elevation. The snake slipped into a forest stream and there were no further sightings despite intensive search. 
Thamnodynastes corocoroensis Gorzula and Ayarzagüena

Thamnodynastes corocoroensis Gorzula and Ayarzagüena, "1995" [1996]: 6-8, fig. 1 (drawings of dorsal and lateral head scalation). Holotype MHNLS 11376 from Tepuy Corocoro, $2150 \mathrm{~m}$, Estado Bolívar [Estado Amazonas], Venezuela $\left(05^{\circ} 46^{\prime} \mathrm{N}, 66^{\circ} 11^{\prime} \mathrm{W}\right)$, collected on November 10, 1987.

This recently described snake, known only from the holotype, is from $2150 \mathrm{~m}$ elevation in the high northwestern quadrant of Cerro Corocoro. The type locality, originally given as being in Bolívar state, was corrected to Amazonas state by Gorzula and Señaris (1999: 180, 255 [locality H-017]).

\section{COMPARISONS}

The unique specimen of Thamnodynastes corocoroensis comes from only some $30 \mathrm{~km}$ WNW of neighboring Cerro Yavi, type locality of the almost simultaneously described Thamnodynastes yavi Myers and Donnelly. Based solely on comparison of the original descriptions, the holotype of $T$. corocoroensis differs from the type specimens of $T$. yavi in aspects of coloration in life and in relative tail length.

Thamnodynastes corocoroensis was described as having in life a whitish vertebral line (presumably confined mainly to the vertebral scale row), as well as two dorsolateral light lines along scale rows 5 and $6 .{ }^{29}$ In contrast, T. yavi in life (Myers and Donnelly, 1996: fig. 25) lacked a whitish vertebral line and had suggestions either of dark dorsolateral lines or rows of vague dark spots, which extended posteriorly from two parallel dark stripes on the nape and which tended to fuse again as a pair of solid lines on the rear of

\footnotetext{
${ }^{29}$ The description of the two pale "paravertebral" (i.e., high lateral or dorsolateral) lines, as given, would normally mean that the line on each side occupies all or adjacent parts of scale rows 5 and 6 along the length of the body. However, since there is scale-row reduction, the authors more likely described line position from only one place on the body. There must be a posterior drop in position of the lateral stripe unless scale-row reduction involves paravertebral or other dorsal scales above row 6. Method of reduction was not specified for Tham nodynastes corocoroensis, but only lateral rows (usually $3+4$ ) have been implicated for $T$. chimanta, T. duida, and T. yavi.
}

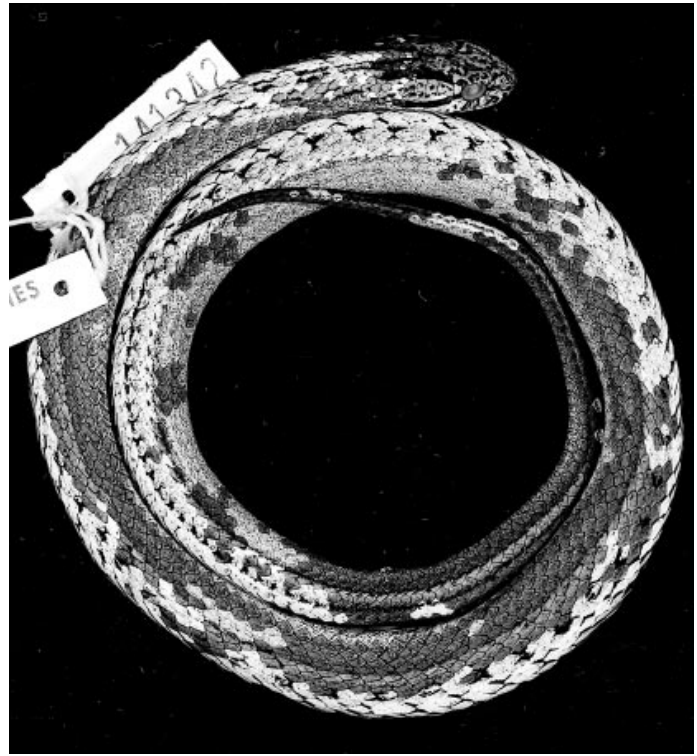

Fig. 49. Thamnodynastes yavi, a paratopotype (AMNH 1413420) from Cerro Yaví; for same specimen in life, see color photograph in Myers and Donnelly (1996: fig. 25, upper). Note that this is not a full dorsal view; the coiled body is inclined to its left, giving a nearly lateral view that includes only part of the dorsum. The light gray areas, where stratum corneum has been lost, show hints of pale vertebral and dorsolateral lines said to be evident in life in T. corocoroensis from Cerro Yutajé (Gorzula and Ayarzagüena, "1995" [1996]: 8).

the body and tail. Thamnodynastes yavi in life also had slightly darker (grayish brown) sides that were edged above with a narrow blackish line extending mainly along row 5 anteriorly and row 4 posteriorly.

There would seem to be little resemblance in the dorsal colorations of $T$. corocoroensis and T. yavi in life. After preservation, however, repeated handling for examination eventually causes loss of the stratum corneum in most snakes, and specimens of Thamnodynastes then become a lighter gray. The available specimen (AMNH 141132 $\widehat{0}$ ) of Thamnodynastes yavi has faded somewhat after four years in preservative, turning lighter brown over areas of still-existing stratum corneum, and gray where the corneal layer has been lost (fig. 49). This specimen was reexamined to see if it might have indications of the pale vertebral and dorsolateral lines 
that were ascribed to living $T$. corocoroensis. Although there is a reduction in density of melanophores, the vertebral row in the specimen of yavi is only very slightly paler than the paravertebral rows; it does not give the impression of being a pale line or narrow stripe. Also owing to a reduction in melanophores, there is a paleness above the vague blackish lateral line, mainly along rows 5 (anteriorly) and 4 (posteriorly). Under certain conditions of lighting, when the specimen is immersed in alcohol, this pale edging seems to include row 6 on the anterior part of the body, as well as the upper part of row 5; one can then imagine a pale stripe on rows 5 and 6. These linear areas of reduced melanophore density seem likely to be either precursors or remnants of the pale lines described for $T$. corocoroensis. Thamnodynastes yavi, apparently unlike $T$. corocoroensis, has vague dorsolateral black markings rising from black nape stripes and posteriorly fusing to form a pair of paravertebral black lines; these black markings are more evident after loss of the stratum corneum (fig. 49).

Thamnodynastes yavi seems to be noticeably different from $T$. corocoroensis in having anteriorly distinct dark ventrolateral stripes. Ventral or ventrolateral striping is not mentioned in the description of $T$. corocoroensis, but the ventral surfaces of the two taxa seem otherwise to be similarly colored.

The female holotype of Thamnodynastes corocoroensis was stated to be $258 \mathrm{~mm}$ in total length ("longitud total"), $74 \mathrm{~mm}$ in tail length (tip of tail possibly incomplete) - the tail accordingly being at least $28.7 \%$ of total length. Relative tail length therefore may be greater in $T$. corocoroensis than in $T$. yavi, for which lengths of 22.9 and $23.3 \%$ were recorded for two females and $24.1 \%$ for one male. If these two named taxa represented only one species, the range in variation of nearly 6\% (22.9-28.7\%) for females (and a minimum overlap of $4.6 \%$ between sexes) is conceivable, but unlikely to be represented in a sample of only four specimens. For comparison, relative tail length for 10 Thamnodynastes chimanta was $18.5-21.0 \%$ in three females and $18.6-25.6 \%$ in seven males, with means of $19.93 \%$ ond $21.60 \%$ o (as summarized by Myers and Donnelly [1996: 47] from available data).

\section{REMARKS}

Considering the geographic proximity of the type localities on Cerro Corocoro and Cerro Yaví, we had rather expected these snakes to be conspecific, although the preceding comparisons suggest that they are distinct. Nonetheless, direct comparison of specimens would be useful. Except for one paratopotype (AMNH 141342) of T. yavi, the type specimens of both taxa are now in Venezuelan institutions. ${ }^{30}$

The possible conspecificity of two additional species named from neighboring tepuis (Duida/Marahuaka)_Thamnodynastes marahuaquensis Gorzula and Ayarzagüena, and Thamnodynastes duida Myers and Donnelly_is perhaps more problematic inasmuch as each is known only from a single specimen. The holotype of $T$. duida is a male 455 $\mathrm{mm}$ in total length (tail $=22.2 \%$ ), whereas the holotype of $T$. marahuaquensis is a female $396 \mathrm{~mm}$ in total length (tail $=23.0 \%$ ). The specimen of $T$. duida has only 17 scale rows on the anterior half of the body (1717-15), whereas T. marahuaquensis has 19 rows up to the level of ventrals $87 / 88$ (i.e., the standard scale-row formula $=19-19-$ $15^{31}$ ). Each has four ventral stripes (a com-

\footnotetext{
${ }^{30}$ Along with the holotype and a paratopotype, there is an additional specimen of Thamnodynastes yavi in the Museo de la Estación Biológica de Rancho Grande at Maracay. All specimens were taken on the 1995 American Museum-Terramar Expedition, but the additional specimen was caught when we were on another tepui, and it was accidentally transported to Maracay in a container of alcohol-preserved bats. We were unaware of its existence until February 1995, after delivering half our collection and a copy of our in-press manuscript to the Profauna office in Caracas.

${ }^{31}$ The original description of T. marahuaquensis gave a formula of "19-17-15" to indicate reduction. However, the shorthand scale reduction formula most commonly used shows counts (1) about a head length behind the head, (2) at midbody, and (3) a head length or less anterior to the vent (e.g., J. Peters, 1964: 312). Thus, the standard formula is $19-19-15$ for T. marahuaquensis, which implies that reductions to 17 and to 15 rows take place posterior to midbody. "Midbody" can be estimated if dorsal-scale reductions are linked to ventral counts. For example, in T. marahuaquensis reduction from 19 to 17 rows was said to occur at the level of ventrals $87 /$ 88 -well past midbody at roughly $64 \%$ of the distance from the first to the last (137th) ventral plate. These differences in scale-row annotation appear to have confused Kornacker (1999: 140), whose unsuccessful key to Venezuelan Thamnodynastes shows only one species
} 
mon character in the genus) and generally seems to resemble the smaller $T$. chimanta more than the geographically closer $T$. corocoroensis and T. yavi.

Any revisionary work involving these taxa unfortunately will have to contend with the fallacious "Junio 1995" publication date of Gorzula and Ayarzagüena's paper, which appeared as number 6 of the Publicaciones de la Asociación de Amigos de Doñana (Sevilla). In acknowledging receipt of this paper on July 1, 1996, one of us expressed regret at having overlooked a year-old publication (letter, Myers to Ayarzagüena). Soon afterwards, however, herpetologist Ignacio de la Riva, a member of the journal's editorial committee, visited the American Museum in August 1996, and said that he had not previously seen that issue and had been unaware of its existence. Subsequent query revealed that the paper also had been received in Bogotá in the summer of 1996 , but that investigators were still unaware of it at such herpetological centers as the Paris Museum, the U.S. National Museum of Natural History, and the Museum of Comparative Zoology.

Attempts to find holding libraries, from which dates of receipt could be obtained, were unsuccessful. According to John Cadle (in litt.), the reference librarian at the $\mathrm{Mu}-$ seum of Comparative Zoology reported to him in August 1996 that "Neither the library databases nor the directories of associations list them [i.e., La Asociación de Amigos de Doñana]. I tried searching the Spanish library catalogues directly, but didn't have any luck." More recently (December 1999), a computer search was performed by reference librarians at the American Museum, with the following results:

We looked for the publication in the National Library of Spain, other European libraries, university libraries, and OCLC [Online Computer Library Center, Inc.]. We used the [name of the journal] and the author and title of the article,

$\leftarrow$

(T. yavi) as having 19 midbody scale rows, whereas that count also pertains to $T$. corocoroensis, T. marahuaquensis, and probably $T$. strigilis. Northern Venezuelan specimens assigned to the last species (Roze, 1966: 229-230) should be compared with Thamnodynastes gambotensis, described from the Caribbean lowlands of northern Colombia (Pérez-Santos and Moreno, 1989). on the off-chance that the article itself was individually catalogued. This gave us no results. We accessed the ISSN site online and determined that the ISSN number [1132-8398] is a registered number, but after re-running the same search with the ISSN no. (which should be a sure way of tracking it down, as numbers are less messy than text), we still came up with no hits. Unfortunately, we were not able to access the University of Seville's online catalog, as it is only available to the University of Seville community. We were hoping that since the publication is put out in Seville, they would have a copy. ${ }^{32}$

Evidently not! During a trip to the Universidad de Sevilla in February 2000, Ms. Tracy Hogan inquired about the publication, and her colleagues there initiated a search, only to find that, as of March 3, 2000, the general library had no records of the Publicaciones de la Asociación de Amigos de Doñana, and that it had not been found during a search by the librarian in the School of Biology. Attempts were being made by Universidad de Sevilla representatives to find out more about the Seville-based Asociación de Amigos de Doñana and to obtain their publications for the library.

Therefore, it would appear that issues of the Publicaciones de la Asociación de Amigos de Doñana are not routinely sent to libraries, and that the separately issued numbers are distributed mainly by the authors.

Darrel Frost, who has tried to document time of publication for various journals that frequently bear erroneous dates, wrote to the President of the Asociación in March 1997, asking if there were records for precise dates of publication. He received a polite response that, however, did not address the question. Dr. de la Riva (in litt.) said that issue number 6 was sent out around June 1996, but that nobody could provide a particular date of publication.

In summary, no evidence could be found that issue number 6 of the Publicaciones de la Asociación de Amigos de Doñana was published any earlier than some unknown time in June 1996 - a year later than the published date ("Junio 1995"). In lacking an unbiased, objectively determined date, the day of publication for taxonomic purposes must

\footnotetext{
${ }^{32}$ Some issues have been printed in Venezuela, but number 6 was printed in Spain.
} 
be assigned according to the last-day-of-themonth rule (i.e., June 30, 1996) of the International Code of Zoological Nomenclature (International Commission, 1999: art. 21.3.1 and 21.4).

\section{DISCUSSION}

Our sampling of the the amphibians and reptiles of the Yutajé-Corocoro massif was not expected to provide a complete faunal list, but the results do reinforce several emerging generalities about the herpetofauna of Pantepui: (1) Tepuis have relatively depauperate herpetofaunas; (2) neighboring tepuis are likely to have significantly different faunas; (3) tepui endemics outnumber widespread highland species; (4) some endemic species have widespread counterparts, the remnants perhaps of a once widespread tepui fauna; and (5) lowland species find their way onto tepuis in an irregular, unpredictable manner. Following is a brief elaboration of these points.

1. Species diversity clearly is limited on the tepuis, perhaps a general reflection of biotic impoverishment on poor soils. Beyond that, experience suggests that sizes of tepui faunas are (as would be expected) positively correlated with area and negatively correlated with elevation (Myers and Donnelly, 1997: 64). The recorded number of species in a given tepui herpetofauna also reflects collecting effort. In terms of collecting effort and actual area sampled, the size of our present collection from the Yutajé-Corocoro massif is very roughly comparable with several other collections that we have made:

Cerro Guaiquinima: 15 spp. from 1030-1150 m (12 days)

Pico Tamacuari: 12 spp. from 1160-1460 m (6 days)

Yutajé-Corocoro: 9 spp. from $1220 \mathrm{~m}$ and 1700 $1750 \mathrm{~m}$ (7 days)

Cerro Yaví: 7 spp. from 2150 m (5 days)

Increased collecting effort over a greater area naturally yields more species, with known faunas of 15-25 species on the best-sampled large tepuis (Myers and Donnelly, 1997: 64).

2. Data showing profound differences between the herpetofaunas of neighboring tepuis are only just accumulating. The best documented example is that of Auyantepui and Chimantá-these large tepuis are continuous at the $1000 \mathrm{~m}$ contour and their high summits $(>2000 \mathrm{~m})$ stand less than $50 \mathrm{~km}$ apart. However, their summits share less than $50 \%$ of the families represented (5 of 11), only $38 \%$ of the genera (9 of 24), and only about $15 \%$ of the known species (about 4 of 26 spp. total), as tabulated by Myers (1997). ${ }^{33}$

The northwestern tepuis (Yaví, YutajéCorocoro, Guanay) provide additional data on differences among neighboring tepuis. The small summit of Cerro Yaví is less than $20 \mathrm{~km}$ airline distance from equivalent elevation on the Yutajé-Corocoro massif. Furthermore, a system of ridges connects the northern bases of these mountains, so past (but probably not current) faunal interchange seemed likely and evidently did occur. Of the combined fauna of 14 species, three $(21 \%)$ are known to be shared. The lack of more extensive overlap between neighboring Yaví and Yutajé-Corocoro can be explained in part by ecological differences. Cerro Yaví, for example, lacks summit streams, which at the Yutajé camp yielded two frogs and a sighting of a riparian snake, and the summit of Yaví is perhaps too high for the lizard Tropidurus. Nonetheless, the snake genus Thamnodynastes appears to be represented by different species on Yaví and Yutajé-Corocoro, and our samples of two of the three shared species seem to show evidence of geographic differentiation! Eleutherodactylus yaviensis seems to be an earless frog on Cerro Yaví, whereas a flimsy concealed tympanum is present in part of the small Yutajé sample. Furthermore, the meager data suggest the existence of population differences in stripe width and size of median gular scales in the lizard Prionodactylus goeleti.

Study of our collection from Cerro Guanay is in progress. The new lizard Tropidurus panstictus appears to be the same species as one on Cerro Guanay, but otherwise there is

\footnotetext{
${ }^{33}$ Chimantá fauna based mainly on the works of Gorzula (1992) and Roze (1958b). Auyantepui fauna based mainly on results of the 1937-1938 Phelps Venezuelan Expedition of the American Museum of Natural History (Roze, 1958a) and the 1994 Robert G. Goelet American Museum-Terramar Expedition to Auyantepui (Myers and Donnelly, in prep.). See Myers (1997: 1-2) for acknowledgment of other collectors on Auyantepui.
} 


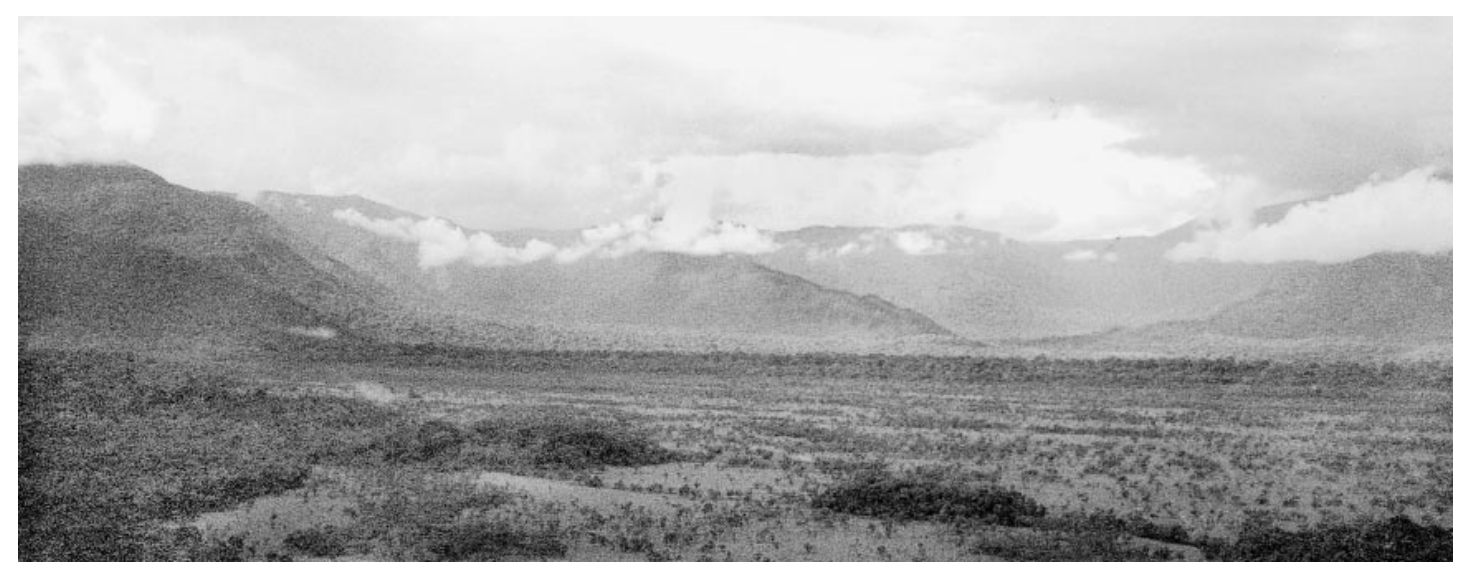

Fig. 50. A ridge corridor between the northern base of Cerro Yaví and the northeastern base of Cerro Yutajé. Viewed from a helicopter, looking northeastward. The ridge crests were very roughly estimated from the air as ranging from perhaps $600 \mathrm{~m}$ to more than $1000 \mathrm{~m}$ above sea level (highest elevations of Cerro Yaví and the Yutajé-Corocoro massif $>2100 \mathrm{~m}$ ). Although the ridges between these neighboring tepuis are heavily forested, there is no continuity with higher elevation forest—at least on Cerro Yutajé, where rocky cliffs and scrubland intervene. (Photograph by C. W. Myers, May 8, 2000)

virtually no overlap between Guanay and the other northwestern tepuis. Cerro Guanay lies close to Cerro Corocoro, but is separated by a lowland valley (fig. 1).

3. Excluding various lowland species that invade tepuis (see below), endemic species of amphibians and reptiles are much more likely to be found than widespread highland species. Of 14 species in the combined faunas of Cerro Yaví and Yutajé-Corocoro, at least $11(79 \%)$ appear to be endemic to those tepuis, including the three shared species. In confusing ontogenetic variation with noncorrelated individual variation, Gorzula and Señaris (1999) expressed the opinion that one of the three shared endemic species (Prionodactylus goeleti) is identical with one (P. phelpsorum) named earlier from the tepui Sarisariñama (see page 63). They bolstered this idea with the following scenario:

Prionodactylus phelpsorum [including P. goeleti] is known from the cerros Corocoro, Yutajé and Yaví in the State of Amazonas, and from Cerro Jaua (the type locality) in the State of Bolívar, at elevations ranging from 1800 to $2100 \mathrm{~m}$ asl. The distance between Cerro Jaua and the group of cerros Corocoro, Yutajé and Yaví is about $180 \mathrm{~km}$ in a straight line and about $300 \mathrm{~km}$ following the connecting watersheds. At no point does the watershed drop below an elevation of $950 \mathrm{~m}$ asl. Much of the intervening terrain reached [reaches] elevations of $2000 \mathrm{~m}$ or more. (Gorzula and Señaris, 1999: 140)

Although conceivable, such a broad distribution would be highly unusual for a highland reptile in Pantepui. It is contraindicated by variation as presently understood, including indication of differentiation between populations of $P$. goeleti on neigboring tepuis. Samples are regrettably small.

4. Tepui endemics are likely to have counterparts $^{34}$ on other tepuis, as shown for example by the dwarf members of the snake genus Thamnodynastes, now represented in Pantepui by five named species, including one each on Cerros Corocoro and Yaví. If there is a relatively old and widespread highland fauna of amphibians and reptiles in Pantepui, it is represented by such groups as the the dwarf Thamnodynastes complex, the Oreophrynella complex, the Phenacosaurus neblininus complex, and the endemic Riola$m a$, assuming for the moment that all of these comprise monophyletic highland groups rather than separate invasions from

\footnotetext{
${ }^{34}$ This is a purposely vague term that we use for congeneric species that we judge to be phenotypically and ecologically similar. Phylogenetic closeness is probable, but cladistic analyses are lacking and degree of relatedness is unknown.
} 
the lowlands. Current known distributions seem very spotty, as would be expected by random extinction events. However, the slow ongoing investigation of tepui herpetofaunas will eventually fill in some of the gaps.

We have speculated on aspects of the problem elsewhere (Myers and Donnelly, 1996: 53-54; 1997: 63-67), but additional faunal sampling is needed much more than additional hypothesizing. The highland herpetofaunas of Pantepui remain very poorly known, and we suspect that many more endemics remain to be discovered. Our current report of a new species of microteiid lizard on Cerro Yutajé was unpredictable but scarcely surprising - the only thing truly remarkable is that a new generic name (Adercosaurus) was needed to accommodate it, since there are few endemic genera in highland Pantepui (Riolama is the only other endemic genus of reptiles). This finding underscores the point that the tepuis are poorly explored in a herpetological sense.

5. Lowland species doubtless invade all tepuis, although they may not necessarily reach the highest summits (e.g., none is known on Cerro Yaví), or, if they do, they may not establish permanent populations there. Available habitat for vertical dispersal can be an important factor, as on the huge but relatively low Cerro Guaiquinima, which has a strong lowland component in the herpetofauna (Donnelly and Myers, 1991; Mägdefrau et al., 1991). On occasion, species at first regarded as "tepui species" later come to be seen as widespread animals with extensive elevational ranges (e.g., the lizard Neusticurus racenisi; see Myers and Donnelly, 1997: 61, 65). Lizards of the Anolis chrysolepis complex are perhaps the most frequent invaders of tepui habitats.

Although lowland invaders are expected, they can seldom be successfully predicted. For example, there was no way of anticipating the presence of Pseudopaludicola llanera at $1220 \mathrm{~m}$ on Cerro Corocoro-the first reported tepui occurrence of this lowland genus of miniature frogs. However, discovery of the new lizard Tropidurus panstictus on Cerro Corocoro led to the expectation that $T$. hispidus or the macroteiid Ameiva ameiva might also occur, since both widespread lowland species occurred in sympatry with Tro- pidurus lumarius on Cerro Guaiquinima. But neither was found, although another macroteiid (Kentropyx sp.) occurred prominently with Tropidurus panstictus on Cerro Guanay! Appearance of lowland species in tepui faunas seems to be regulated mostly by opportunity and chance, and we see no general pattern emerging.

\section{ACKNOWLEDGMENTS}

The 1995 expedition was made possible by the generosity and commitment of $\mathrm{Mr}$. Robert G. Goelet, former president and Chairman Emeritus of the Board of Trustees of the American Museum of Natural History.

As acknowledged in our earlier report, the expedition would not have been successfully concluded or even started without the essential help and splendid collaboration from many Venezuelan friends and colleagues. For help with permits and contracts, we thank Dr. Armando Michelangeli Ayala, President of Fundación TERrAMAR; General Francisco Loreto, then President of the Instituto Nacional de Parques (INPARQUES); and several officials in the Servicio Autónomo para la Protección, Restauración, Fomento y Racional Aprovechamiento de Fauna Silvestre y Acuática del País (ProfAUNA)—especially former Director-General Dr. José Luis Méndez Arocha, Directora-General Lic. Mirna Quero de Peña, and Ms. Magaly Ojeda C., Directora de Fauna Silvestre.

Mrs. Kathleen D. de Phelps, of the Colección Ornitologica Phelps, expressed great interest in the work and expedited it in every possible way.

Expedition planning was facilitated in September 1994, when Dr. Luis Arturo Ayala, of Terramar, piloted his Piper Seneca in an initial reconnaissance that gave Michelangeli, Guerrero, and Myers a close look at the northwestern tepuis. We gratefully acknowledge the Venezuelan Air Force (FAV) for subsequently providing a military transport plane for moving personnel and supplies to base camp on February 4, 1995, and for evacuating the expedition on March 4. The expedition base was Yutajé, a backcountry fishing camp run by José Félix Raggi.

Owing to limits placed by PROFAUNA on the number of persons in a single camp, the 
expedition had two or three camps simultaneously open in the northwestern tepuis during February 4-March 2. It was an extremely efficient operation owing to logistical planning by expedition leader Armando Michelangeli, and support from helicopter pilot $\mathrm{Ri}$ cardo Trevisi and mechanic Juan Vasconcelos. Their experience allowed the scientific teams to establish five wilderness camps on three tepuis in a month's time.

We were air-lifted on February 24 from Cerro Yaví to the 1700-m Cerro Yutajé camp, evacuating it on March 2. The Yutajé camp had been first opened on February 11 by TERRAmar members José Clavijo and José Luis García (Museo del Instituto de Zoología Agricola, Univ. Central de Venezuela, Maracay), Miguel Lentino and the late Gilberto Pérez-Chinchilla (Colección Ornitologica Phelps), Juan Carlos Navarro (Instituto de Zoología Tropical, Univ. Central de Venezuela, Caracas), with expert support from Terramar staff members Williams Sarmiendo and Aleizer Zerpa.

Our campmates in the 1700-m camp on Cerro Yutajé included George F. Barrowclough and Paul R. Sweet (AMNH Dept. Ornithology), Francisco Delascio Chitty and Aniusk Kazandjian (Herbario Nacional de Venezuela, InPARQues), John W. Daly (National Institutes of Health and AMNH Dept. Herpetology), Ricardo Guerrero (Instituto de Zoología Tropical, Univ. Central de Venezuela, and TERrAmar), and Petia Alcócer and Adriana Sánchez H. (TERRAMAR).

For comments on various parts of the manuscript or for other help, we are grateful to George F. Barrowclough, John E. Cadle, Charles J. Cole, Julián Faivovich, Linda S. Ford, Darrel R. Frost, Taran Grant, Ricardo Guerrero, Dennis M. Harris, David A. Kizirian, Ignacio de la Riva, Paul R. Sweet, and Richard G. Zweifel. Drawings were prepared by Patricia J. Wynne. Photographs of preserved specimens are the work of Peter Goldberg (photographs of living specimens and landscapes were taken by the first author). Thomas Trombone prepared a radiograph of the lizard Adercosaurus.

For their help in trying to determine the actual date of publication of a problematic paper, we thank Michelle Anastasia and Meghan Manahan, Reference Librarians in the American Museum, and Mary Sears, Reference Librarian in the Museum of Comparative Zoology at Harvard University. Their investigations were extended on a visit to Seville by Tracy Hogan (Montclair State University), who received valuable assistance from Drs. Isabel L. Calderon and Ignacio Martinez of the Universidad de Sevilla.

\section{REFERENCES}

Avila-Pires, Teresa C. S.

1995. Lizards of Brazilian Amazonia (Reptilia: Squamata). Zool. Verh. 299: 706 pp.

Barbour, Thomas

1928. New Central American frogs. Proc. New England Zool. Club 10: 25-31 + 4 color pls.

Boulenger, George Albert

1879. Quelques observations relatives à la forme de la pupille et à la coloration de l'iris chez certains batraciens. Bull. Soc. Zool. France 4: 129-131.

1885. Catalogue of the lizards in the British Museum (Natural History), 2nd ed. Vol. 2, xiii, 497 pp. +24 pls.

1900. Reptiles and Batrachians. In E. R. Lankester, Report on a collection made by Messrs. F. V. McConnell and J. J. Quelch at Mount Roraima in British Guiana. Reptiles. Trans. Linn. Soc. London, Zool., ser. 2, 8(2): 53-56 + pl. 5.

Camp, Charles L.

1923. Classification of the lizards. Bull. Am. Mus. Nat. Hist. 48(11): 289-481. [Reprinted in facsimile in 1971 by Society for the Study of Amphibians and Reptiles, with a new Preface by Camp and a new introduction by G. Underwood.]

Cole, Charles J., Herbert C. Dessauer, Carol R. Townsend, and Margaret G. Arnold

1990. Unisexual lizards of the genus Gymnophthalmus (Reptilia: Teiidae) in the Neotropics: genetics, origin, and systematics. Am. Mus. Novitates 2994: 29 pp.

Dixon, T. H.

1991. An introduction to the global positioning system and some geological applications. Rev. Geophys. 29(2): 249-276.

Donnelly, Maureen A., and Charles W. Myers

1991. Herpetological results of the $1990 \mathrm{Ve}-$ nezuelan expedition to the summit of Cerro Guaiquinima, with new tepui 
reptiles. Am. Mus. Novitates 3017: 54 pp.

Donnelly, Maureen A., Roy W. McDiarmid, and Charles W. Myers

1992. A new lizard of the genus Arthrosaura (Teiidae) from southern Venezuela. Proc. Biol. Soc. Washington, 105(4): 821-833.

Duke-Elder, Sir Stewart

1958. The eye in evolution. System of ophthalmology, vol. 1 , xvi +843 pp. St. Louis: C. V. Mosby.

Estes, Richard

1983. Sauria terrestria, Amphisbaenia. Handb. Paläoherpetol. 10A: xxii +249 pp.

Estes, Richard, Kevin de Queiroz, and Jacques Gauthier

1988. Phylogenetic relationships within Squamata. In R. Estes and G. Pregill (eds.), Phylogenetic relationships of the lizard families: 119-281. Stanford, CA: Stanford Univ. Press.

Flores, Glenn

1985. A new Centrolenella (Anura) from Ecuador, with comments on nuptial pads and prepollical spines in Centrolenella. J. Herpetol. 19(3): 313-320.

Frost, Darrel R.

1992. Phylogenetic analysis and taxonomy of the Tropidurus group of lizards (Iguania: Tropiduridae). Am. Mus. Novitates 3033: 68 pp.

Gosner, Kenneth L.

1960. A simplified table for staging anuran embryos and larvae with notes on identification. Herpetologica 16(3): $183-$ 190.

Gorzula, Stefan

1992. La herpetofauna del macizo del Chimantá. In O. Huber (ed.), El macizo del Chimantá: 267-280 + 304-310 (= photographs 152-171). Caracas: Oscar Todtmann Editores.

Gorzula, Stefan, and José Ayarzagüena

“1995" [1996]. Dos nuevas especies del género Thamnodynastes (Serpentes; Colubridae) de los tepuyes de la Guayana Venezolana. Publ. Asoc. Amigos de Doñana 6: $17 \mathrm{pp}$. [assigned publ. date = June 30, 1996; see text].

Gorzula, Stefan, and J. Celsa Señaris

1999. Contribution to the herpetofauna of the Venezuelan Guayana I. A data base. Sci. Guaianae 8: xviii +268 pp. +129 color photos [in 32 end pls.], maps 2 5 in pocket ["1998" on cover, but explicitly January 20, 1999 on reverse of inside title page].
Grant, Taran, Elaine C. Humphrey, and Charles W. Myers

1997. The median lingual process of frogs: a bizarre character of Old World ranoids discovered in South American dendrobatids. Am. Mus. Novitates 3212: 40 pp.

Harris, Dennis M.

1985. Infralingual plicae: support for Boulenger's Teiidae (Sauria). Copeia 1985 (3): 560-565.

1994. Review of the teiid lizard genus Ptychoglossus. Herpetol. Monogr. 8: 226275.

Hitchcock, Charles B.

1947. The Orinoco-Ventuari region, Venezuela. Geogr. Rev. 37(4): 525-566 + foldout map.

1948. La región Orinoco-Ventuari, Venezuela. Bol. Soc. Venezolana Cienc. Nat. 11(72): 131-179 + foldout map (translation of 1947 paper).

Huber, Otto

1995a. Geographical and physical features. In J. A. Steyermark, P. E. Berry, and B. K. Holst (general eds.), Flora of the Venezuelan Guayana, vol. 1: 1-61. St. Louis: Missouri Botanical Garden.

1995b. History of botanical exploration. In J. A. Steyermark, P. E. Berry, and B. K. Holst (general eds.), Flora of the Venezuelan Guayana, vol. 1: 63-95. St. Louis: Missouri Botanical Garden.

1995c. Vegetation. In J. A. Steyermark, P. E. Berry, and B. K. Holst (general eds.), Flora of the Venezuelan Guayana, vol. 1: 97-160. St. Louis: Missouri Botanical Garden.

International Commission on Zoological Nomenclature

1999. International code of zoological nomenclature, 4th ed. London: International Trust Zoological Nomenclature, xxxix + 306 pp.

Kornacker, Paul M.

1999. Checklist and key to the snakes of Venezuela. Lista sistemática y clave para las serpientes de Venezuela. Rheinbach, Germany: Pako-Verlag, 270 pp. +90 color illus. in 16 pls.

La Marca, Enrique

1993. Phylogenetic relationships and taxonomy of Colostethus mandelorum (Anura: Dendrobatidae), with notes on coloration, natural history, and description of the tadpole. Bull. Maryland Herpetol. Soc. 29(1): 4-19.

“1996” [1998]. Ranas del género Colostethus (Amphibia: Anura; Dendrobatidae) de 
la Guayana Venezolana con la descripción de siete especies nuevas. Publ. Asoc. Amigos de Doñana 9: 64 pp.

1997. Lista actualizada de los reptiles de Venezuela. In E. La Marca (ed.), Vertebrados actuales y fósiles de Venezuela, vol. 1: 123-142. Mérida, Venezuela: Museo de Ciencia y Tecnología de Mérida.

Lancini V., R. Abdem

1968. El género Euspondylus (Sauria: Teiidae) en Venezuela. Publ. Ocas. Mus. Cienc. Nat. (Caracas), Zool. 12: 8 pp.

Lobo, Fernando

1994. Primera cita de Pseudopaludicola boliviana Parker, 1927, para el Brasil y nuevos registros el Paraguay. Cuad. Herpetol. 8(2): 230-231.

1995. Analisis filogenético del género Pseudopaludicola (Anura: Leptodactylidae). Cuad. Herpetol. 9(1): 21-43.

Lynch, John D.

1989. A review of the leptodactylid frogs of the genus Pseudopaludicola in northern South America. Copeia 1989 (3): 577 588.

Lynch, John D., and William E. Duellman

1973. A review of the centrolenid frogs of Ecuador, with descriptions of new species. Occas. Pap. Mus. Nat. Hist., Univ. Kansas 16: 66 pp.

1980. The Eleutherodactylus of the Amazonian slopes of the Ecuadorian Andes (Anura: Leptodactylidae). Univ. Kansas Mus. Nat. Hist. Misc. Publ. 69: [iv] $+86 \mathrm{pp}$.

1997. Frogs of the genus Eleutherodactylus in western Ecuador. Univ. Kansas Nat. Hist. Mus. Spec. Publ. 23: iv + 236 pp +8 pls.

Mägdefrau, Helmut

1991. Plica nigra, ein neuer Leguan von Guaiquinima Tepui (Venezuela) (Sauria, Iguanidae). Spixiana 14: 229-234.

Mägdefrau, Helmut, Karin Mägdefrau, and Andreas Schlüter

1991. Herpetologische Daten vom Guaiquinima-Tepui, Venezuela. Herpetofauna (Germany) 13(70): 13-26.

MacLean, William P.

1974. Feeding and locomotor mechanisms of teiid lizards: functional morphology and evolution. Pap. Avulsos Zool. (São Paulo) 27(15): 179-213.

Mayr, Ernst, and William H. Phelps, Jr.

1967. The origin of the bird fauna of the South Venezuelan highlands. Bull. Am.
Mus. Nat. Hist. 136(5): 269-327 + pls. 14-21, foldout map.

Myers, Charles W.

1991. Distribution of the dendrobatid frog Colostethus chocoensis and description of a related species occurring macrosympatrically. Am. Mus. Novitates 3010: 15 pp., 8 figs.

1997. Preliminary remarks on the summit herpetofauna of Auyantepui, eastern Venezuela. Acta Terramaris 10: 1-8.

2000. A history of herpetology at the American Museum of Natural History. Bull. Am. Mus. Nat. Hist. 252: 232 pp.

Myers, Charles W., and Maureen A. Donnelly

1996. A new herpetofauna from Cerro Yaví, Venezuela: first results of the Robert G. Goelet American Museum-TerRAMAR expedition to the northwestern tepuis. Am. Mus. Novitates 3172: 56 pp.

1997. A tepui herpetofauna on a granitic mountain (Tamacuari) in the borderland between Venezuela and Brazil: report from the Phipps Tapirapecó Expedition. Am. Mus. Novitates 3213: 71 pp.

Myers, Charles W., and William E. Duellman

1982. A new species of Hyla from Cerro Colorado, and other tree frog records and geographical notes from western Panama. Am. Mus. Novitates 2752: 32 pp.

Myers, Charles W., John W. Daly, and Borys Malkin

1978. A dangerously toxic new frog (Phyllobates) used by Emberá Indians of western Colombia, with discussion of blowgun fabrication and dart poisoning. Bull. Am. Mus. Nat. Hist. 161(2): 307$366+$ color pls. 1-2.

Myers, Charles W., Alfredo Paolillo O., and John W. Daly

1991. Discovery of a defensively malodorous and nocturnal frog in the family Dendrobatidae: phylogenetic significance of a new genus and species from the Venezuelan Andes. Am. Mus. Novitates 3002: 33 pp.

Myers, Charles W., Lily O. Rodríguez, and Javier Icochea

1998. Epipedobates simulans, a new cryptic species of poison frog from southeastern Peru, with notes on E. macero and E. petersi (Dendrobatidae). Am. Mus. Novitates 3238: 20 pp.

Neuwirth, Maria, John W. Daly, Charles W. Myers, and Lois W. Tice

1979. Morphology of the granular secretory glands in skin of poison-dart frogs 
(Dendrobatidae). Tissue Cell 11(4): 755-771.

Pérez-Santos, Carlos, and Ana G. Moreno

1989. Una nueva especie de Thamnodynastes (Serpentes: Colubridae) en el norte de Colombia. Boll. Mus. Reg. Sci. Nat. Torino 7(1): 1-9.

Peters, James A.

1964. Dictionary of herpetology. A brief and meaningful definition of words and terms used in herpetology. New York: Hafner, ix, 392 pp. + 30 figs.

Peters, Wilhelm.

"1862" [1863]. Über Cercosaura und die mit dieser Gattung verwandten Eidechsen aus Südamerica. Abh. Phys. Kl. K. Akad. Wiss. Berlin 1862(4): 165-225 +3 pls. [Available in 1995 SSAR facsimile reprint, The herpetological contributions of Wilhelm C. H. Peters (1815-1883): 175-197.]

Phelps, William H., Jr.

1977. Aves colectadas en las mesetas de Sarisariñama y Jaua durante tres expediones al macizo, Estado Bolívar. Descripciones de dos nuevas subespecies. Bol. Soc. Venezolana Cienc. Nat. 33, 134: 15-42 + 2 maps.

Presch, William

1978. Descriptions of the hemipenial morphology in eight species of microteiid lizards (family Teiidae, subfamily Gymnophthalminae). Herpetologica 34(1): 108-112.

1980. Evolutionary history of the South American microteiid lizards (Teiidae: Gymnophthalminae). Copeia 1980 (1): 36-56.

1983. The lizard family Teiidae: is it a monophyletic group? Zool. J. Linn. Soc. 77: 189-197.

Rivero, Juan A.

"1982" [1984]. Sobre el Colostethus mandelorum (Schmidt) y el Colostethis inflexus Rivero (Amphibia, Dendrobatidae). Mem. Soc. Cienc. Nat. La Salle 42(118): 9-16.

Roze, Janis A.

1958a. Los reptiles del Auyantepui, Venezuela, basándose en las colecciones de las expediciones de Phelps-Tate, del American Museum of Natural History, 19371938, y de la Universidad Central de Venezuela, 1956. Acta Biol. Venezuelica 2(22): 243-270.

1958b. Los reptiles del Chimantá Tepui (Estado Bolívar, Venezuela) colectados por la expedición botánica del Chicago
Natural History Museum. Acta Biol. Venezuelica 2(25): 299-314.

1966. La taxonomia y zoogeografía de los ofidios en Venezuela. Caracas: Univ. Central Venezuela, 362 pp.

Rubin, L., P. Eller, and J. Nolte

1986. Fine structure of the photosensitive iris of the toad, Bufo marinus. J. Morphol. 188: $225-238$.

Ruibal, Rodolfo

1952. Revisionary studies of some South American Teiidae. Bull. Mus. Comp. Zool. 106(11): 477-529.

Ruiz-Carranza, Pedro M., and John D. Lynch

1991a. Ranas Centrolenidae de Colombia I. Propuesta de una nueva clasificación genérica. Lozania (Acta Zool. Colombiana) 57: $30 \mathrm{pp}$.

1991b. [Same title] II. Nuevas especies de Centrolene de la Cordillera Oriental y Sierra Nevada de Santa Maria. Lozania (Acta Zool. Colombiana) 58: 26 pp.

Ruiz-Carranza, Pedro M., María Cristina ArdilaRobayo, and John D. Lynch

1996. Lista actualizada de la fauna de Amphibia de Colombia. Rev. Acad. Colombiana Cienc. 20(77): 365-415.

Savage, Jay M., and W. Ronald Heyer

1967. Variation and distribution in the treefrog genus Phyllomedusa in Costa Rica, Central America. Beitr. Neotrop. Fauna 5(2): 111-131.

Schmidt, Karl P.

1932. Reptiles and amphibians of the Mandel Venezuelan Expedition. Field Mus. Nat. Hist., Zool. Ser. 18(7): 159-163.

Steyermark, Julián A., and Charles BrewerCarias

1976. La vegetación en la cima del macizo de Jaua. Bol. Soc. Venezolana Cienc. Nat. 32,132/133: 179-405.

Uzzell, Thomas

1969. The status of the genera Ecpleopus, Arthroseps and Aspidolaemus (Sauria, Teiidae). Postilla (Peabody Mus. Nat. Hist. Yale Univ.) 135: 23 pp.

1973. A revision of lizards of the genus Prionodactylus, with a new genus for $P$. leucostictus and notes on the genus Euspondylus (Sauria, Teiidae). Postilla (Peabody Mus. Nat. Hist. Yale Univ.) 159: $67 \mathrm{pp}$.

Walls, Gordon Lynn

1942. The vertebrate eye and its adaptive radiation. Cranbrook Inst. Sci. Bull. 19: xiv + 785 pp. [Reprinted 1963, with same pagination, by Hafner Publ. Co., New York and London.] 